DOI: https://dx.doi.org/10.24093/awej/th.282

Theses ID 282

Pp. $1-106$

\title{
The Impact of Telegram on Syntactic Complexity of the Saudi Female EFL Undergraduates' Argumentative, Classification, and Reaction Essays
}

\author{
Lamyaa Falah AIMohaya \\ Al-Imam Muhammad Ibn Saud Islamic University \\ Saudi Arabia \\ Email: lamyaa.almohaya@gmail.com
}

Author: Lamia Falah AlMohaya

Thesis Title: The Impact of Telegram on Syntactic Complexity of the Saudi Female EFL

Undergraduates' Argumentative, Classification, and Reaction Essays

Institution: Al-Imam Muhammad Ibn Saud Islamic University

Degree: Master

Major: Applied Linguistics

Year of award: 2020

Supervisor: Dr. Talal Musaed Alghizzi

ORCid ID: https://orcid.org/0000-0002-4753-2296

Keywords: EFL student, learning environment, syntactic complexity, Telegram, text types

\section{Abstract:}

The aim of this exploratory experimental quantitative is to investigate the impact of the learning environment and text types on the syntactic complexity of female Saudi students majoring in English language. Specifically, the study seeks to explore how and when the syntactic complexity of these students increases/decreases as a whole and across the fourteen measures of syntactic complexity (MLS, MLT.MLC.C/S, VP/T, C/T, DC/C, DC/T, T/S, CT/T, CP/T, CP/C, $\mathrm{CN} / \mathrm{T}, \mathrm{CN} / \mathrm{C}$ ) in two learning contexts: traditional learning context (TLC) and blended learning context (BLT) across three writing tasks (argumentative, classification , and reaction). It purports, also, to find out when and which learning context leads to the most/least increase/decrease in the syntactic complexity (as a whole and across specific measures) of Saudi undergraduate in the three writing tasks. To answer such questions, 48 female Saudi EFL undergraduate students were recruited from the pool of level six students. The participants were randomly divided into the control and experimental groups. The control group consisted of 28 students; while the experimental group was comprised of 20 students. The 288 students' writing productions were analyzed according to the fourteen measures of syntactic complex by using a paired t-test and an independent $t$ test. For the first question, the results of this study show that there was no increase/decrease in syntactic complexity, either as a whole or partially across individual measures, for the control group for the three writing tasks (argumentation, classification, and reaction). This would suggest that traditional learning method does not reach to level to be significant to the participants in the control group. For the second research question, the t-tests showed that the syntactic complexity of the participants in the experimental group increased as a 
whole in both the classification and reaction essays. An increase in complexity was shown across the following measures for the classification essay: MLS, MLT, MLC, CN/T/VP/T, and CN/C. For the reaction essay, an increase in complexity was shown across MLS, MLT, MLC, and CN/T measures. Although the syntactic complexity of these participants did not increase/decrease as a whole for the argumentation essay, the CN/T measure did show some increase. Finally, the comparison between the results of the two groups revealed that, although the experimental group in this study showed more improvement in syntactic complexity than the control group, the degree of difference between the two groups was too small to draw any definite conclusion about the relative effectiveness of the two methods. This may be due to the comparatively short duration of the study: ten weeks. The findings of this research have significant implications for academic research and for Saudi EFL teachers at the university level.

Cite as: AlMohaya, L. F. (2022). The Impact of Telegram on Syntactic Complexity of the Saudi Female EFL Undergraduates' Argumentative, Classification, and Reaction Essays, Al-Imam Muhammad Ibn Saud Islamic University (M.A.Thesis). Retrieved from Arab World English Journal (ID Number: 282) Novermber, 2022: 1-106.

DOI: https://dx.doi.org/10.24093/awej/th.282 
Kingdom of Saudi Arabia

Ministry of Education

Al-Imam Muhammad Ibn Saud Islamic University

College of Languages and Translation

Department of English Language and Literature

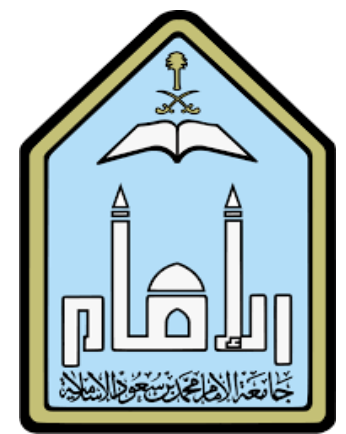

The Impact of Telegram on Syntactic Complexity of the Saudi Female EFL

Undergraduates' Argumentative, Classification, and Reaction Essays

Submitted By

\section{Lamia Falah AlMohaya}

Supervised by

Dr. Talal Musaed Alghizzi

A dissertation submitted in partial fulfillment of the requirements for the MA degree in the Department of English Language and Literature

Safar, 1442-October , 2020 
Thesis Title:

The Impact of Telegram on Syntactic Complexity of the Saudi Female EFL

Undergraduates' Argumentative, Classification, and Reaction Essays

By

Lamia Falah AlMohaya

Department of English Languages and Literature Al-Imam Muhammad Ibn Saud

Islamic University

Date: / / 2020

Has been approved for the Department of English Language and Literature

Dr. Talal Musaed Alghizzi (Supervisor)

Dr. Abdulmajed AlMansour. (Examiner)

Dr. Abdulaziz AlSayegh (Examiner)

The final copy of this dissertation has been examined by the signatories, and we confirm that both the content and the form meet acceptable presentation standards of scholarly work in the above mentioned discipline. 


\begin{abstract}
The aim of this exploratory experimental quantitative is to investigate the impact of the learning environment and text types on the syntactic complexity of female Saudi students majoring in English language. Specifically, the study seeks to explore how and when the syntactic complexity of these students increases/decreases as a whole and across the fourteen measures of syntactic complexity (MLS, MLT.MLC.C/S, VP/T, $\mathrm{C} / \mathrm{T}, \mathrm{DC} / \mathrm{C}, \mathrm{DC} / \mathrm{T}, \mathrm{T} / \mathrm{S}, \mathrm{CT} / \mathrm{T}, \mathrm{CP} / \mathrm{T}, \mathrm{CP} / \mathrm{C}, \mathrm{CN} / \mathrm{T}, \mathrm{CN} / \mathrm{C}$ ) in two learning contexts: traditional learning context (TLC) and blended learning context (BLT) across three writing tasks (argumentative, classification, and reaction). It purports, also, to find out when and which learning context leads to the most/least increase/decrease in the syntactic complexity (as a whole and across specific measures) of Saudi undergraduates in the three writing tasks. To answer such questions, 48 female Saudi EFL undergraduate students were recruited from the pool of level six students. The participants were randomly and unevenly divided into the control and experimental groups. The control group consisted of 28 students; while the experimental group was comprised of 20 students. The 288 students' writing productions were analyzed according to the fourteen measures of syntactic complex by using a paired t-test and an independent t-test. For the first question, the results of this study show that there was no increase/decrease in syntactic complexity, either as a whole or partially across individual measures, for the control group for the three writing tasks (argumentation, classification, and reaction). This would suggest that traditional learning method does not reach to level to be significant to the participants in the control group. For the second research question, the t-tests showed that the syntactic complexity of the participants in the experimental group increased as a whole in both the classification and reaction essays. An increase in complexity was shown across the following measures for the
\end{abstract}


classification essay: MLS, MLT, MLC, CN/T/VP/T, and CN/C. For the reaction essay, an increase in complexity was shown across MLS, MLT, MLC, and CN/T measures. Although the syntactic complexity of these participants did not increase/decrease as a whole for the argumentation essay, the CN/T measure did show some increase. Finally, the comparison between the results of the two groups revealed that, although the experimental group in this study showed more improvement in syntactic complexity than the control group, the degree of difference between the two groups was too small to draw any definite conclusion about the relative effectiveness of the two methods. This may be due to the comparatively short duration of the study: ten weeks. The findings of this research have significant implications for academic research and for Saudi EFL teachers at the university level.

Key words: EFL student, learning environment, syntactic complexity, Telegram, text types. 


\section{ملخص الدراسة}

تهدف هذه الدراسة التجريبية الاستكشافية إلى دراسة تأثير بيئة التعلم وأنواع النص على التعقيد النحوي للطالبات السعوديات المتخصصات في اللغة الإنجليزية. و تسعى الدراسة إلى استكشاف كيف ومتى يزداد / ينقص التعقيد النحوي لهؤلاء الطالبات ككل وعبر المقاييس الأربعة عشر للتعقيد النحوي في سياقين تعليميين: سياق التعلم التقليدي وسياق التعلم المدمج في ثلاثة أنواع من المقالات (المقال جدلي، مقال التصنيف و مقال رد الفعل).وتهدف أيضًا إلى معرفة متى وأي سياق تعليمي يؤدي إلى أقصى / أقل زيادة / نقص في التعقيد النحوي (ككل وعبر مقاييس محددة) للطالبات الجامعيات السعوديات في مهام الكتابة الثلاث. للإجابة على مثل هذه الأسئلة ، تم اختيار 48 طالبة سعودية من طالبات المستوى السادس. ثمّ تم تقسيم المشاركات بشكل عشوائي وغير متساو إلى مجموعة ضابطة و أخرى تجريبية. تألفت المجموعة الضابطة من 28 طالبة. بينما ضمت المجموعة التجريبية 20 طالبة

تم تحليل الإنتاج الكتابي للطالبات البالغ عدده 288 وفقًا للمقاييس الأربعة عشر للتعقيد النحوي باستخدام اختبار t المزدوج واختبار t المستقل. بالنسبة للسؤال الأول، أظهرت نتائج هذه الدراسة عدم وجود زيادة / نقص في التعقيد النحوي، سواء كليًا أو جزئيًا عبر المقاييس الفردية، للمجموعة الضابطة لمهام الكتابة الثلاث (الجدل ، التصنيف ، ورد الفعل). قد يشير هذا إلى أن طرق التعلم التقليدية لم تصل إلى المستوى الذي يؤثر على المهارات النحوية للمشاركات في المجموعة الضابطة. بالنسبة لسؤال البحث الثاني ، أظهرت اختبارات t أن التعقيد النحوي للمشاركات في المجموعة التجريبية زاد ككل في كل من مقالات التصنيف ورد الفعل بينما لم يزد في المقال الجدلي. كما تمّ تسجيل زيادة في التعقيد النحوي في بعض المقاييس في مقالات التصنيف ورد الفعل والمقال الجدلي كذلك. أخيرًا ، كشفت المقارنة بين نتائج المجموعتين أنه على الرغم من أن المجموعة التجريبية في هذه الدراسة أظهرت تحسنًا في التعقيد النحوي أكثر من المجموعة الضابطة ، فإن درجة الاختلاف بين المجموعتين كانت صغيرة جدًا بحيث لا يمكن استخلاص أي استنتاج محدد حول الفعالية النسبية للطريقتين. قد يكون هذا بسبب قصر مدة الدراسة نسبيًا: عشرة أسابيع. نتائج هذا البحث لها آثار كبيرة على البحث الأكاديمي ومعلمي اللغة الإنجليزية كلغة أجنبية على مستوى الجامعة.

الكمات المفتاحية: طالب اللغة الإنجليزية كلغة أجنبية، بيئة التعلم، التعقيد النحوي، التلغرام، أنواع النص. 


\section{Dedication}

I would like to dedicate this thesis to my dear sister Mona, who tragically passed away. I will not forget her prayers that supported me throughout my thesis. 


\section{Acknowledgements}

Praise be to Allah for giving me the power and determination to complete this thesis.

First, I would like to extend my thanks and gratitude to my supervisor, Dr. Talal Alghizzi, for unflinching help during this research. His patience, feedback and advice have guided this research and brought it to fruition. It has been an honor to be one of his students

Second, I am deeply indebted to my family for their support and encouragement. In particular, I am grateful to my beloved husband, Muhammad Bin Tawallah, for his collaboration, advice, and priceless support. I would also like to express my sincere thanks to my mother, school Principal T. Nouf AlOtaibi, for her love, guidance, and sacrifices. Without her, I wouldn't have finished this thesis. I am also very thankful to my father for his pride in me, and belief in my capabilities.

Finally, my warmest thanks and love go to my dear brothers and sisters. Special thanks also go to my uncle; Professor Fahad Turki Bin Muhaya for the confidence he has bestowed in me. 
Table of Contents

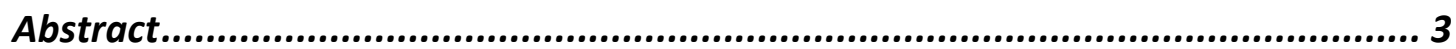

(الدراسة

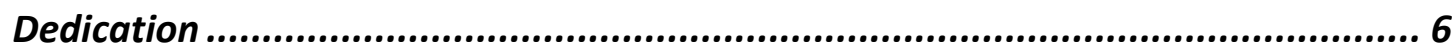

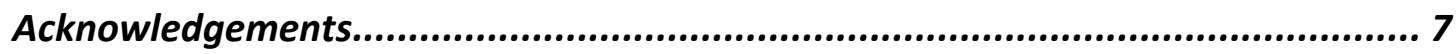

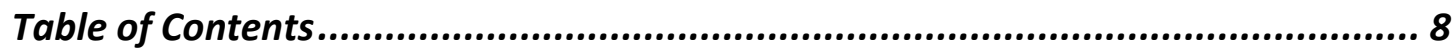

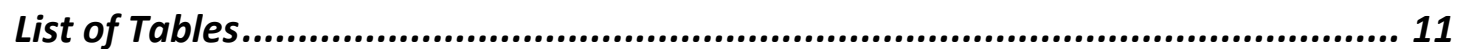

List of Figures.......................................................................................... 12

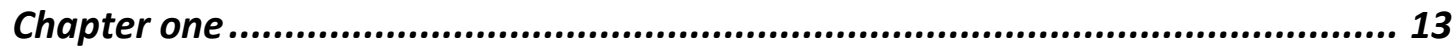

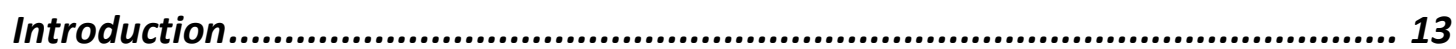

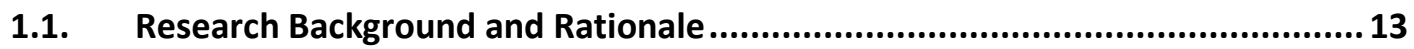

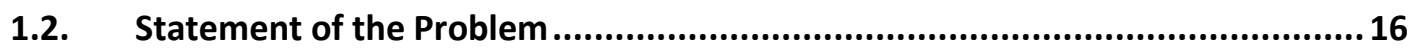

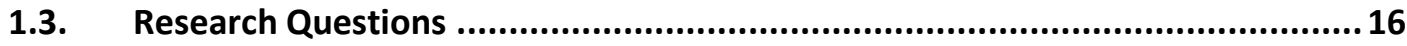

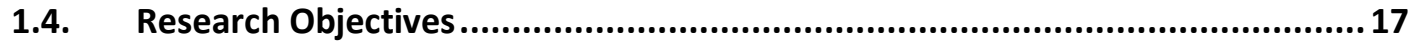

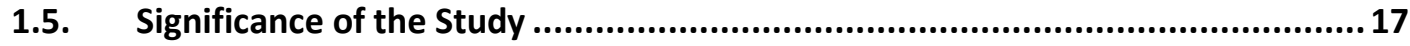

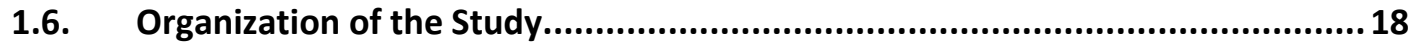

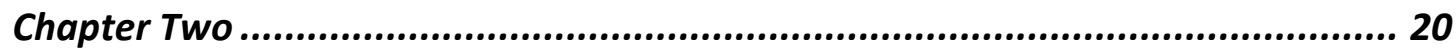

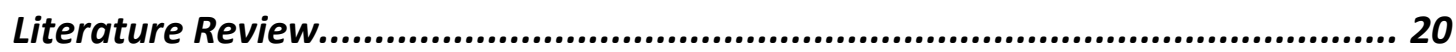

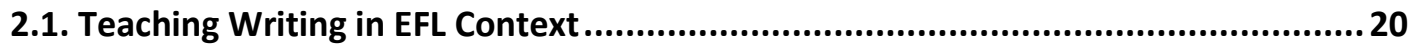

2.1.1. Traditional Classroom Environment ....................................................................20

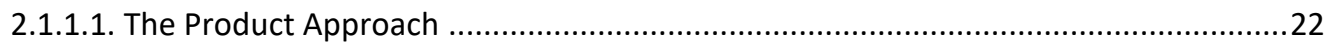

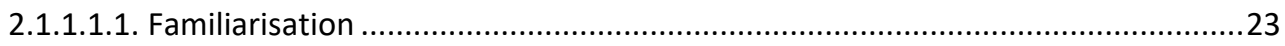

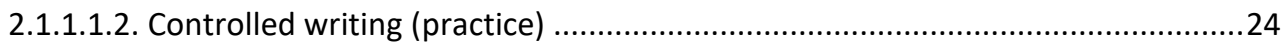

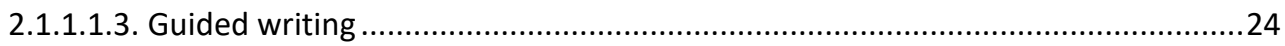

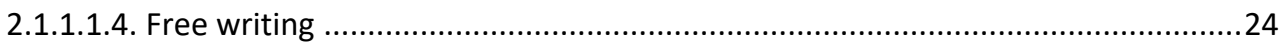

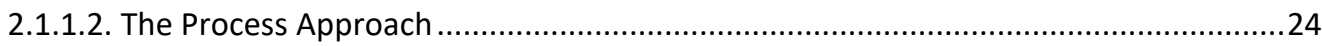

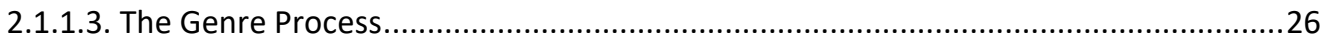

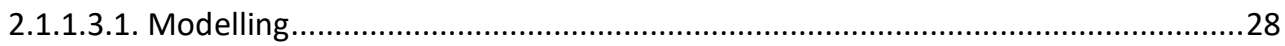

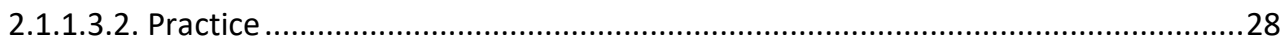

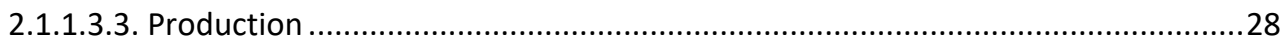

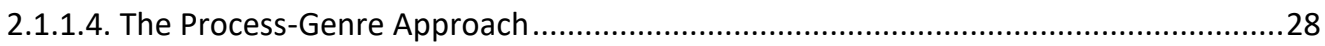

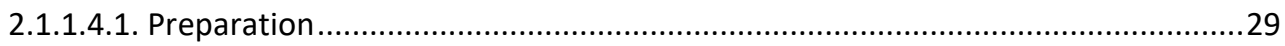

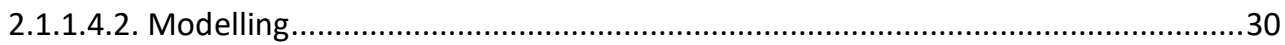

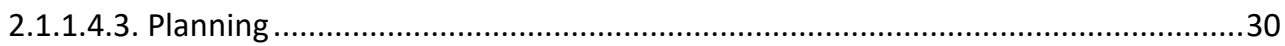

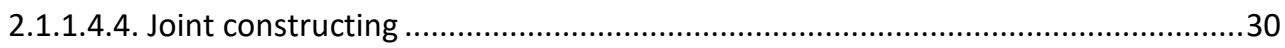

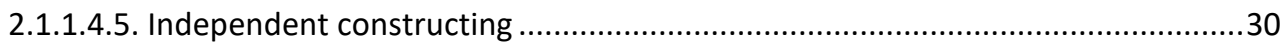

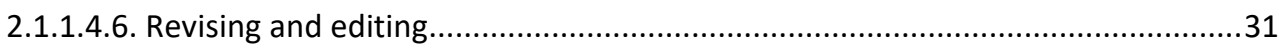

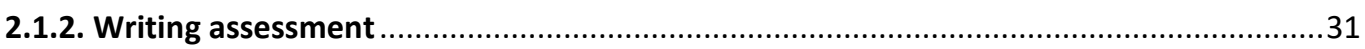

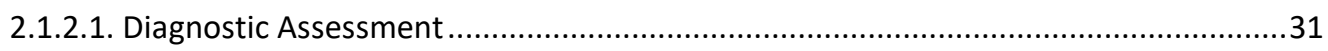

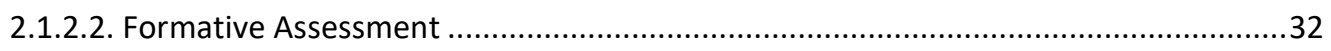




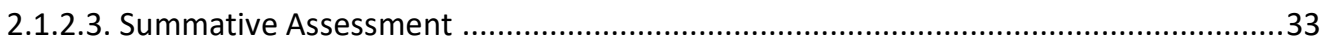

2.2. Blended Learning Context.................................................................... 34

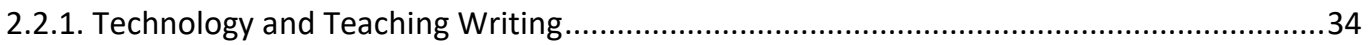

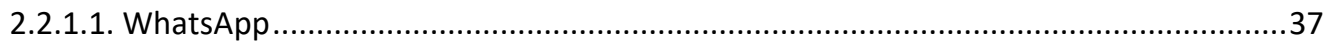

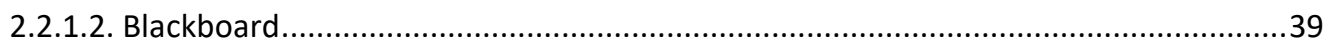

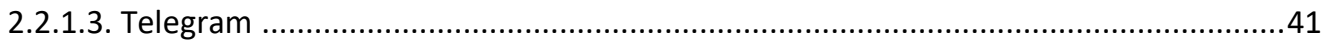

2.3. Assessing Complexity, Accuracy, and Fluency (CAF) ...........................................43

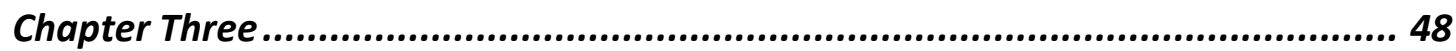

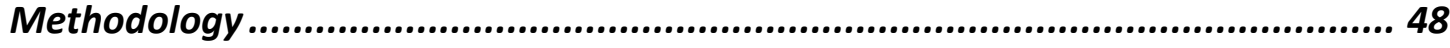

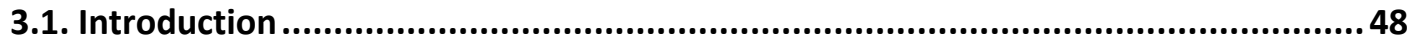

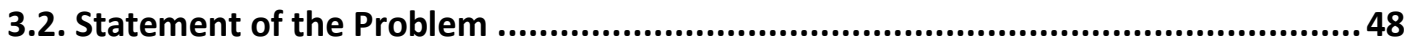

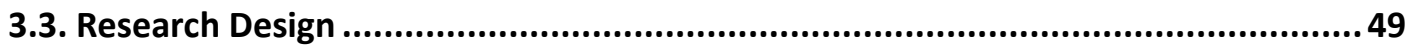

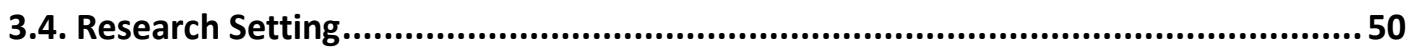

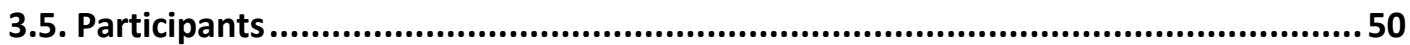

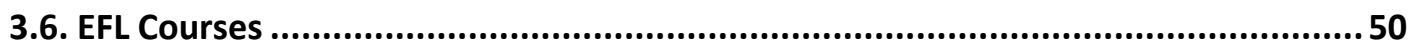

3.7. Teaching Methodology, Teaching/Learning Contexts, and Participants ................51

3.7.1. Traditional learning context group ...............................................................................5 51

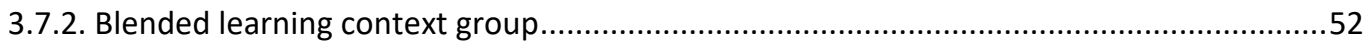

3.8. Materials and procedures for data collection ......................................................5 53

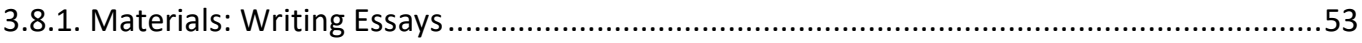

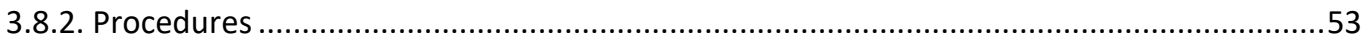

3.9. Ethical Considerations ....................................................................................... 55

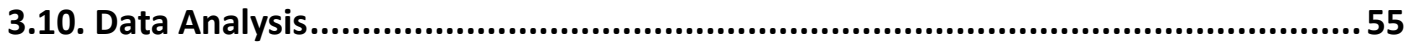

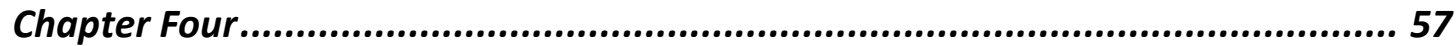

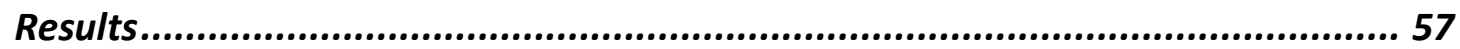

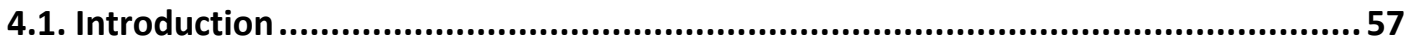

4.2. The Results of Syntactic Complexity of Saudi Participants .....................................55

4.3. Syntactic complexity of the control group .............................................................5 57

4.3.1. Syntactic Complexity of the control group in the Argumentative Essay............................57

4.3.2. Syntactic Complexity of the control group in the Classification Essay..............................60

4.3.3. Syntactic Complexity of the control group in the Reaction Essay....................................61

4.4. Syntactic Complexity in the Experimental Group ...............................................64

4.4.1. The Results of Syntactic Complexity of the experimental group in the Argumentative Essay

4.4.2. The Results of Syntactic Complexity of the experimental group in the Classification Essay .66

4.4.3. The Results of Syntactic Complexity of the Experimental Group in the Reaction Essay.....68

4.5. Improvement of Syntactic Complexity in the Experimental and the Control Groups 
4.5.1. The Results of Syntactic Complexity of the control \&Experimental groups in the Argumentative Essay.....

4.5.2. The Results of Syntactic complexity of the control \&Experimental groups in the Classification Essay...

4.5.3. The Results of Syntactic Complexity of the Control \& Experimental groups in the Reaction

Essay.

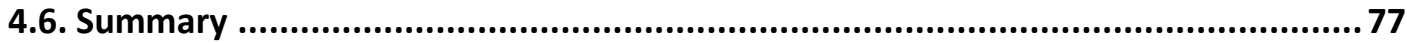

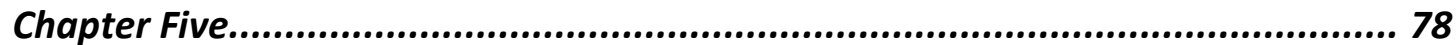

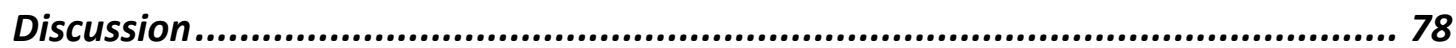

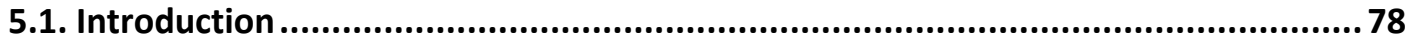

5.2. Research Question One: Did the control group's syntactic complexity increase/decrease for the three writing tasks (argumentation, classification, and reaction) as a whole and/or across specific measures?

5.3. Research Question Two: Did the experimental group's syntactic complexity increase/decrease for the three writing tasks (argumentation, classification, and reaction) as a whole and/or across specific measures?

5.4. Research Question Three: Did the experimental group outperform the control group in syntactic complexity when writing argumentation, classification, and reaction texts and, if so, to what extent?

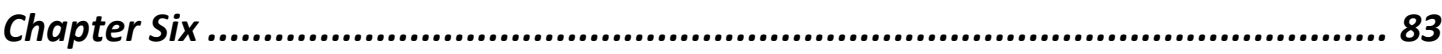

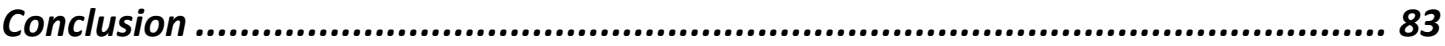

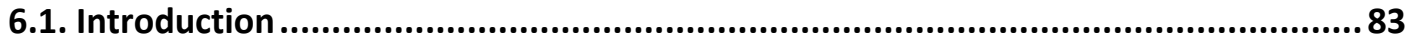

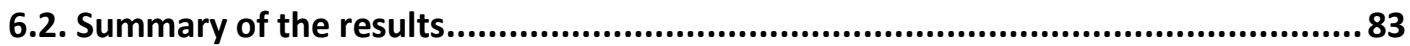

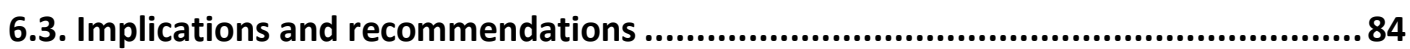

6.4. Limitations and Suggestions for future research ..................................................86

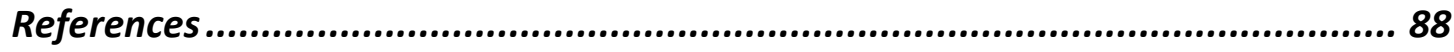

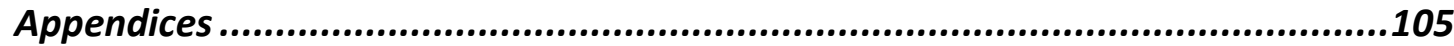

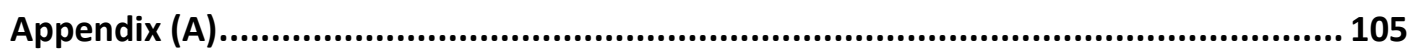

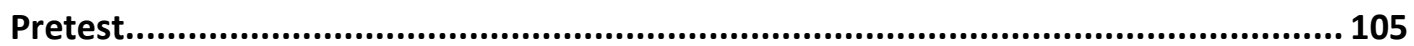

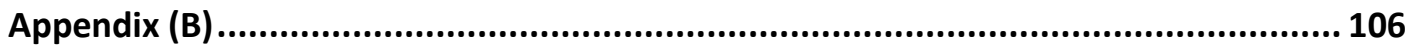

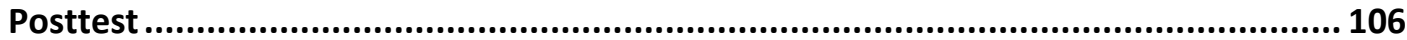




\section{List of Tables}

Table 1:The Comparison Results of the Control Group's Syntactic Complexity in Argumentative Texts.

Table 2:The Comparison Results of the Control Group's Syntactic Complexity in the Classification Texts.

Table 3:The Comparison Results of the Control Group's Syntactic Complexity in the Reaction Texts.

Table 4:The Comparison Results of the Experimental Group's Syntactic Complexity in the Argumentative Texts.

Table 5:The Comparison Results of the Experimental Group's Syntactic Complexity in the Classification Texts

Table 6:The Comparison Results of the Experimental Group's Syntactic Complexity in the Reaction Texts.

Table 7:The Comparison Results of the Control and Experimental Groups' Syntactic Complexity in the Argumentative Texts.

Table 8:The Comparison Results of the Control and Experimental Groups' Syntactic Complexity in the Classification Texts.

Table 9:The Comparison Results of the Control and Experimental Groups' Syntactic Complexity in the Reaction Texts. 


\section{List of Figures}

Figure 1:Control Group's Syntactic Complexity Results as a whole for Argumentative

Essay. .59

Figure 2:Control Group's Syntactic Complexity Results as a whole for Classification

Essay. .61

Figure 3:Control Group's Syntactic Complexity Results as a whole for the Reaction

Essay. .63

Figure 4:Experimental Group's Syntactic Complexity Results as a whole for Argumentative Essay. .66

Figure 5:Experimental Group's Syntactic Complexity Results as a whole for Classification Essay. 68 Figure 6:Experimental Group's Syntactic Complexity Results as a whole for Reaction Essay. 70

Figure 7:Control and Experimental Groups' Syntactic Complexity Results as a whole for Argumentative Essay. .72 Figure 8:Control and Experimental Groups' Syntactic Complexity Results as a whole for Classification Essay. 75 Figure 9:Control and Experimental Groups' Syntactic Complexity Results as a whole for Reaction Essay. 77 


\section{Chapter one}

\section{Introduction}

\subsection{Research Background and Rationale}

The development of students' writing skills has attracted academic interest for many decades. This interest stems from the fact that mastering writing is an essential component of language proficiency. It occupies a central place in both first language (L1) and second language (L2) acquisition. According to Alghizzi (2017), writing is the last skill to be mastered in both L1 and L2, and this mastery comes with its own challenges for native and non-native speakers alike. Therefore, Perin (2013), Fadda (2012) and Alkhairy (2013) consider writing as the most difficult skill to obtain in language learning. English as foreign language (EFL) students in particular often faced problems when learning how to write.

With the advent of technology and social media, approaches to teaching writing have evolved. Rahma, Bandjarjani, and Andanty (2018) maintain that language learning has hugely benefited from technological advances and social media. These technologies provide language teachers and learners with valuable tools and opportunities to master language skills. Therefore, as Shirinbakhsh and Saeidi (2018) argue, language teachers face the challenge of incorporating new technologies and motivating students to use them and become independent learners. According to Aghajani and Adloo (2018), Telegram is one of the applications that have recently been applied in EFL classrooms. Rahma et al. (2018) have found out that Telegram offers language learners and teachers an opportunity to collaborate and communicate effectively and helps teachers deliver clear instructions, engage and manage students, and give real-time feedback. These benefits make Telegram an appropriate tool to incorporate into the teaching writing skills as it endorses students' achievements and 
saves time in class. Therefore, it is worth investigating the potential of Telegram in developing the writing skills of EFL learners.

Social media offer teachers and learners a flexible and friendly platform where extra-curricular activities take place to enhance the learning process. A few studies have verified the efficiency of technology in developing students' writing skills. For instance, Al-Jarf (2009) demonstrated that writing can be developed and improved through the use of such technologies as mind-mapping software. Allam and Elyas (2016) found that teachers' opinions of the use of social media are mixed. Their study also concluded that, for many teachers, the use of social media can motivate Saudi college students to learn about writing, while for others, the use of mobile phones and social media in the EFL context can be misused. Fattah (2015) and AlSaleem (2013) addressed the use of WhatsApp in teaching writing and concluded that it has a positive impact on developing the writing of EFL students. Ahmed (2015) investigated the use of Twitter and concluded that it has great value in teaching writing to undergraduate students.

Heidar and Kaviani (2016) maintained that Telegram is a particularly effective tool for learning English because it can be used on mobile devices as well as computers and because it supports audio-visual features. Research on Telegram has shown that it improves the overall writing performance of students, in terms of content, language, diction, and structure (Aghajani \& Adloo, 2018). Heidar and Kaviani (2016) found that Telegram offers EFL learners a unique opportunity to develop their vocabulary online. According to Shirinbakhsh and Saeidi (2018), Telegram has a positive impact on students' motivation when learning reading. Rahma et al. (2018) argued for Telegram's positive influence on learning to write. However, the impact of Telegram on the 
syntactic complexity of EFL learners remains unexamined. This study seeks to fill a gap in the literature by investigating this issue.

Like all EFL learners, Saudi students often face difficulties when learning how to write. Rababah (2003), Hatim (1990), and Ezza (2010) argue that the proficiency levels of Saudi EFL students are rather low. In a study conducted by Grami (2010), Saudi International English Language Testing System (IELTS) candidates scored 5.17, 4.97, and 5.81 out of nine in listening, reading, and speaking, respectively, and 4.83 out of nine in writing. Javid and Umer (2014) studied the writing proficiency of Saudi students; one such study found that Saudi students struggle with syntactic problems, even at the sentence level.

Research on the writing difficulties of Saudi EFL students has thus far focused on the causes of and factors behind these problems. A study carried out in 2011 in Saudi Arabia by Al-Seghayer found that Saudi EFL teachers lacked both language competence and language-teaching skills. Al-Seghayer based this research on a study carried out by the Saudi Ministry of Education in 2004. In a later study, Al-Seghayer (2015) maintains that EFL teachers in the Arab world are part of the problem, as they generally lack the training needed for teaching writing. Similarly, Fareh (2010) believe that EFL teachers tend to focus more on helping students pass their exams than how to write effectively. Moreover, Saudi EFL teachers poorly integrate teaching aids (projectors, language labs, videos etc.), which is why writing represents a major challenge for Saudi students (Abdul Haq, 1982). Most EFL classrooms in the Arab world are traditional; in many of them, the implementation of technology is still a novelty. 


\subsection{Statement of the Problem}

The teaching of writing seems to be directly affected by technological advances; thus, the integration of technology into writing is necessary. The use of Telegram in teaching English has become a major subject in academic research. Linguists and methodologists are constantly looking for ways to successfully implement Telegram in EFL classrooms. The current study maintains that the impact of using Telegram to improve Saudi students' performance in the complexities of syntactic writing is significant. Saudi EFL classes are generally traditional. In traditional classrooms, teachers do not usually have enough time to deal with each learner individually. Therefore, they do not generally have the chance to give each student valuable feedback on their work. Without this feedback, it is difficult to trace the development of these students' proficiencies over time. Accordingly, the need to integrate new technologies to fill in this gap has become urgent. This thesis seeks to study the impact of Telegram on developing syntactic complexity among Saudi EFL students with the aim of shedding light on the differences between blended and traditional EFL contexts insofar as syntactic complexity is concerned.

\subsection{Research Questions}

This thesis is primarily concerned with the effect of Telegram on Saudi EFL syntactic complexity. In so doing, the thesis has addressed the following questions:

1. Did the control group's syntactic complexity increase/decrease for the three writing tasks (argumentation, classification, and reaction) as a whole and/or across specific measures? 
2. Did the experimental group's syntactic complexity increase/decrease for the three writing tasks (argumentation, classification, and reaction) as a whole and/or across specific measures?

3. Did the experimental group outperform the control group in syntactic complexity when writing argumentation, classification, and reaction texts and, if so, to what extent?

\subsection{Research Objectives}

The thesis has two objectives:

1. To discover which learning context - traditional or blended-leads to better development of students' syntactic complexity in three writing tasks: argumentative, classification, and reaction essays.

2. To measure the effect of Telegram on Saudi EFL students' syntactic complexity in three writing tasks: argumentative, classification, and reaction essays.

\subsection{Significance of the Study}

Based on the available literature, the use of Telegram in EFL classrooms has recently begun to increase. However, current research regarding the use of Telegram in the academic field is still in its infancy. This study will contribute to the discussion of using Telegram to develop syntactic complexity within the Saudi context. The relevance of this study lies in the fact that it will provide empirical data on how the use of Telegram might affect the writing complexity of EFL students. There have been some attempts to measure the benefits of using Telegram as a teaching tool. These include Yinka and Queendarline (2018) and Nabati (2018). For instance, Yinka and Queendarline (2018) conducted research through the use of a questionnaire filled out by 300 college students at the University of Port Harcourt, Rivers State. Their study 
targeted students of different disciplines, including the humanities, curricula, and education. The major finding of the study was that Telegram is capable of being a valuable extension of classroom activities.

An EFL study carried out by Nabati (2018) explored the benefits of Telegram on the writing accuracy and grammar of students. The 20 participants were given writing instructions and grammar points exclusively through Telegram. The results showed that the students' accuracy improved remarkably in the posttest. Sarvari and Ezzati (2019) made a similar attempt to determine the role of Telegram in teaching writing in an EFL context. Their study included 46 EFL learners who were taught writing through Telegram for eight weeks. The results showed significant improvement in the overall writing performance of the participants. The current study differs from previous studies in two aspects. First, this research would include an experimental group and a control group, totaling 48 students. This will allow for comparisons to be made in the posttest between the writing skills of the two groups, which will help validate the hypothesis. Second, this study would target one area of writing: syntactic complexity. It is much easier to measure the development of students in a specific field of writing than to measure their overall writing performance.

\subsection{Organization of the Study}

This study is structured as follow: Chapter one is the introduction of the study. It offers a brief overview of the study and research questions. Chapter two reviews the current literature and discusses the syntactic complexity in the EFL context. Chapter three explains the methodology of the study, the research design, the participants and the research tool. Chapter four discusses the results of the study. Chapter five summarizes and discusses the results of the study. Chapter six concludes the study by 
discussing the pedagogical implications of the study, the limitations and the suggestions for future research. 


\section{Chapter Two}

\section{Literature Review}

\subsection{Teaching Writing in EFL Context}

Teaching writing in English as a Foreign Language (EFL) education has evolved into an important area of academic investigation. It occupies a central place in EFL context. This importance is explained, according to Browker (2007), by pointing out that writing, as a skill, is needed in many formal and informal contexts. Hidayati (2018) believes that, in EFL contexts, writing occupies the center of the learning process. According to Brown (2000), writing is a way of life that helps students pass the course. In addition, Afrin (2016) states that writing is widely used to assess the academic performance of students at all stages of education. Given this importance in the academic context, the teaching of writing in first (L1) and second (L2) EFL courses is the subject of a substantial body of research that seeks to not only identify the difficulties encountered by students, but also to propose viable solutions. Afrin (2016) maintains that the difficulties students encounter in writing vary according to learner differences, cultural contexts, and the teaching approach. As new technologies emerge, EFL classrooms become more and more dependent on them. This chapter reviews the literature on the teaching of writing in EFL education in general and in Saudi Arabia specifically. To get a better idea of the development of the theories in this field of research, this chapter covers both the traditional and the blended approaches to the teaching of writing.

\subsubsection{Traditional Classroom Environment}

Teaching writing in the EFL context is a crucial task because it is the foundation of communicative and linguistic competence. Thuy (2009) explains that the process 
poses several difficulties for both learners and teachers. Teachers are expected to be proficient in L2, to be able to develop the writing abilities of learners, and to have a thorough knowledge of various relevant techniques. Leki, Cumming, and Silva (2008) maintain that the challenge of teaching writing in the EFL classroom is largely due to the constant development of new teaching techniques. Studies conducted in this field cover both traditional and modern techniques of teaching writing in EFL classrooms. The available literature distinguishes between traditional classroom environments, as defined by Yitong ,Yinghui ,Hao, and Jianqing (2017) as face-to-face (FTF) teaching, and blended learning, described as 'the integration of traditional classroom methods with online activities (termed "e-learning")' (Yitong et al., 2017, p. 219).

The process of writing is a cognitive activity. According to Babalola (2012), writing is a complex activity of cognition in which the learner could handle several variables at the same time and turn them into a product that is both coherent and cohesive. These variables include spelling, sentence structure, content, word choice, and grammar. In a similar vein, Kellog (2008) maintains that writing is a 'cognitive challenge' (p. 7), because it involves not only the use of language, but also memory and the ability to reason. Therefore, writing is not a natural skill. Harmer (2001) defines it as an acquired skill that requires the learner to possess a certain degree of verbal ability to ensure cohesion and coherence in the text. Kellogg (2008) and Harmer (2001) agree that this verbal ability is not possible without a good command of grammar, diction, punctuation, syntax, spelling, topic sentences, coherence, and the techniques of synthesis and argument.

Given this complexity, teaching writing skills is of the utmost importance in the contexts of both L1 and L2. Harmer (2001) identifies four paramount motives for emphasizing the teaching of writing to EFL students: reinforcement-producing 
sentences using new language structures; cognitive operation - the construction of text; as a tool for teachers to identify the learning style of each student in order to devote individual time accordingly; and because it is one of the four fundamental skills that learners must master.

Despite its recognized importance, according to Alghizzi (2017), writing is the last mastered skill in L1 and L2, and this mastery comes with its own challenges for native and non-native speakers alike. Writing is considered the most difficult skill to acquire in language learning (Richards \& Renandya, 2002; Alsamadani, 2010; Perin, 2013; Hashim, 1996; Rababah, 2003; Al-Khairy, 2013; Fadda, 2012; Javid, Farooq, \& Umer, 2013). Some researchers, such as Al-Buainain (2009), ascribe this difficulty to the fact that writing is the least practiced skill in L1 and L2. In the following sections, we shall examine various approaches proposed in the literature that build upon and complement each other. These include product, process, genre, process-genre and writing assessment.

\subsubsection{The Product Approach}

One of the early approaches to teaching writing is the product approach. As the name indicates, this approach focuses on students' final written product. Tangpermpoon (2008) states that this approach is used to develop and enhance the writing skill of the learner in the target language through an emphasis on grammatical and syntactic structures. Accordingly, Badger and White (2000) maintain that this approach places significant emphasis on syntax, vocabulary, and cohesion. Hasan and Akhand (2010) explain that this approach presents students with a model text to analyze and mimic in their writing. The model is a standard text that students can follow, but Jackson (2006) points out that it does not require students to be innovative, as the final 
product matters more than the writing process. For example, while students may learn new words from the model text, when asked to produce their own writing, they rely on the same words and phrases from the model. On the other hand, Pasand and Haghi (2013) have observed that students mimic, duplicate, and transform the model text to produce a coherent and error-free piece of writing.

The product-based approach is commonly practiced around the world. Its proponents, such as Nunan (1999), feel that its focus on the final product helps L2 students learn to write. According to Saeidi and Sahebkheir (2011), the product approach based on modelling encourages students to design their writing according to a text with which they are familiar and serves as an effective tool for overcoming lexical and grammatical difficulties. Tangpermpoon (2008) explains, 'Students will start from pre-writing to composing and to correcting. In this approach, what is emphasized is raising students' awareness, especially in grammatical structures' (p.5). Badge and White (2000) identify the following four stages of the product approach:

\subsection{Familiarization}

In this stage, students are presented with a model text introduced to them as a standard text. Students read the text and identify the features of its genre, such as the stylistic and grammatical features. For example, if the model text is a story, the teacher focuses on the techniques employed to render the story interesting. Once the techniques are identified, students are then required to track these techniques in the text and understand how they are used. As the name suggests, this stage seeks to familiarize and equip students with specific genres and their techniques. They can then mimic these techniques when they produce their own writing. 


\subsection{Controlled writing (practice)}

This stage takes students from theory to practice. The teacher gives the learners a series of exercises related to the grammatical and lexical features of the model text. While the first stage familiarizes students with these features in the context of the text, this stage requires students to understand and practice them in isolation. For instance, if the model text is a formal letter, this stage may focus on the linguistic structures used to make formal requests, suggestions, and inquiries.

\subsection{Guided writing}

This is the most important stage, because it involves the organization of ideas. Ghufron (2018) believes that organizing ideas is as important as language control in the second stage and more important than the ideas themselves.

\subsubsection{Free writing}

During this stage, students practice free writing. They write a text similar to the model but in their own style. This is the end-product of the learning process. The aim is to demonstrate the students' fluency and competence in the language. To achieve this, students rely on the grammatical and lexical features of the model text. The major criticism of the product approach to teaching writing is its focus on the end product, neglecting the process that leads to this product.

\subsubsection{The Process Approach}

The process-based approach emerged as a reaction to the old product-based approach and became widely used in EFL classrooms. The 1970s and most of the 1980s witnessed a shift from a product to a process approach in teaching writing. In a process approach, emphasis falls on the various activities that lead to the production of a text. 
Muncie (2002) and Feez (2001) believe that these activities, which include planning, drafting, editing, and revising, occur in the pre-writing stage. However, this approach also met with criticism, as many researchers argued that it merely complements the product approach - that the process is an integral part of achieving the end product.

Muncie (2002) claims that the lack of an exact definition of the process approach makes it difficult to evaluate its effectiveness. For Feez (2001), the process approach is a form of creative writing that needs time, patience, and constructive feedback to succeed. The EFL teacher no longer assigns a topic to students and waits for the finished product; there is a good deal of teacher involvement in the process. According to Steele (1992), the teacher intervenes in a variety of classroom activities, such as group discussion and brainstorming, to develop language use. These activities are meant to involve students in the steps of producing a work of writing and to raise their awareness that, while no writing is perfect, these help them come closer to perfection. This is done mainly through brainstorming, reflecting, drafting, and revising. According to Fowler (1989), the process approach was developed to mimic the process of writing in L1 and allow students to express themselves better in L2. These ideas about the process-based approach testify to the fuzziness of the approach and the controversy it evoked.

Unlike the product approach, the process approach treats writing in terms of organizational skills, such as drafting and editing. Linguistics skills like grammar and vocabulary are relegated to a secondary position. The process approach follows a number of steps. Available literature suggests that there is no widely accepted framework to follow, but Tribble (1996) delineates four steps in this approach: prewriting, drafting (sometimes called composing), revising, and editing. Badger and White (2000) argue that this process is cyclical, as writers continuously go back to the pre-writing stage after editing and revising. In the pre-writing stage, students may 
engage in brainstorming about the topic, while the drafting stage requires students to select and organize the results of the brainstorming. In the revising stage, students engage in discussions with their teacher and peer and revisit their first draft. During the final stage, students edit their texts for mistakes before submitting it.

The role of the teacher in the process approach is essential. The teacher not only facilitates the learning experience, but also helps students develop their language. Hyland (2003) maintains that the process of learning language in this approach has been likened to L1 acquisition, because the learner absorbs rather than consciously learning the skill of writing. The teacher helps them achieve their potential. The problem with the process approach, according to Tribble (1996), is that writing is seen as monolithic. All types of writing go through the same process, regardless of content, genre, and writer. They do not recognize the specificities of each genre. Therefore, this approach does not teach learners that an academic paper is different from an informal email to a friend. In conclusion, the process approach treats writing as an unconscious process and the practice of linguistic skills.

\subsubsection{The Genre Process}

In the academic context, genre is not limited to literature. According to Hammond and Derewianka (2001), the term is widely applied to a set of "predictable and recurring patterns of everyday, academic, and literary texts occurring within a particular culture' (p. 78). Tuan (2011) found that the term 'genre' entered into the discussion of text types in the 1990s, both written and spoken, to group together those that serve the same social purposes. Accordingly, in much of the literature available, genre becomes synonymous with text type. The genre-based approach to teaching writing stresses the relationship between the genre of a text and its context. Badger and White (2000) posit that the genre approach is similar to the product approach and can therefore be considered an 
extension of it. The similarity lies in the fact that both approaches treat writing in predominantly linguistic terms. However, unlike the product approach, the genre-based approach places significant emphasis on the social context of the text.

The genre approach, according to Hyland (2003), helps students understand how language functions in particular social contexts. As stated above, genre is a set of text types that serve the same social purposes, making it essential to understand the social purposes in order to fulfill the communicative function of the text.

There have been various attempts to integrate genre into teaching writing. According to these studies, the genre-based approach must meet certain characteristics to facilitate the learning process - the social and cultural context of the text has to be respected. According to Hammond and Derewianka (2001), the context determines the purpose of the text as well as the linguistic conventions applied therein. The logic behind this argument is that when students are aware of the context, they can produce a text that relates to a specific English language discourse community. Muncie (2002) adds that the audience and the linguistic conventions of the genre need to be addressed. As a result, students need to know the expectations of the readership, in terms of grammar, content, and text structure, in order to produce a comprehensible and accepted text. In this sense, writing becomes an attempt to communicate with specific readers.

Another characteristic of the genre-based approach is that it introduces writing as a social activity. Muncie (2002) anchors this view of writing within the socio-cultural theory of the 1970s, arguing that writing is a social activity that implies the collaboration of the group in the production of knowledge. In other words, writing classes should offer students the opportunity to take part in the activities of exchanging and negotiating meaning with their peers and teacher. Such an opportunity is likely to 
lessen the effects of isolation experienced by many learners in the EFL context. Moreover, Tuan (2011) clarifies that it provides them with positive feedback on their knowledge of language, content, and organization in the writing process. A further characteristic of the genre approach is its emphasis on writer-reader interaction in the process of writing. This approach requires students to be permanently aware of their potential readership and to incorporate the appropriate content accordingly. Finally, Badger and White (2000) argue that the role of the teacher in this approach is limited to that of a guide. He or she engages students in a set of activities to help them learn and gain control of the genre being taught.

Implementation of the genre-based process is very similar to that of the product approach, because it too is based on modeling. A typical genre-based writing class consists of three stages:

\subsection{Modelling}

During this stage, a model of the target genre is introduced to the students. The model is then analyzed to determine its distinctive features.

\subsection{Practice}

This stage engages students in a series of activities meant to give them command of the linguistic forms and structures of the genre.

\subsection{Production}

In this stage, students produce their own text similar to the model.

\subsubsection{The Process-Genre Approach}


The limitations of previous approaches led researchers in EFL and ESL contexts to look for innovative ways to teach writing. Towards the beginning of the 2000 s, it became clear to language experts that no approach is adequate in developing writing skills and that the solution is to combine different approaches. The process-genre approach is one attempt to combine elements from different teaching approaches - the process approach and the genre approach. The process was developed by Badger and White in 2000. Babalola (2012) defines the process-genre approach as a combination of the process use of models with the theories of genre ,and maintains that this combination mitigates the limitations of both approaches by incorporating elements from both. Gao (2007) clarifies that the process-genre approach has some elements usually attributed to the genre approach, such as the importance of context and the purpose of the text, and others that usually characterize the process approach, such as learner response.

In this combined approach, learners study the relationship between the form and the purpose of genre. It employs a number of activities that are recurrent throughout the process, such as prewriting, drafting, editing, and revision. Deng, Chen, and Zhang (2014) pose that through these activities learners become aware of the relationship between form and purpose in a particular genre. These activities help students develop awareness of not only the writing process but also the different text types. Moreover, Yan (2005) suggests that because this approach requires students to identify the social context of the genre, it helps them relate it to real-life situations. When they relate it to real life, students are more likely to be motivated to write outside the classroom. Badger and White specify six stages:

\subsection{Preparation}


The teacher prepares the students for the writing activity by introducing a situation to them and asking them to write a text within a particular genre. This stage allows students to figure out and anticipate the linguistic and structural characteristics of the genre.

\subsection{Modelling}

In this stage, students are given a model representative of the genre. They study the model and identify its purpose. At the same time, they are introduced to the structural and linguistic features of the genre.

\subsection{Planning}

This stage involves several collaborative activities that seek to develop students' interest in the topic. These activities include reading related material, brainstorming, and discussion with peers and teacher.

\subsection{Joint constructing}

As the name implies, this stage joins the teacher and the students in the writing process. The teacher employs brainstorming, drafting, and revising. The students generate ideas and information while the teacher writes their text on the white/black board. The text then serves as the model for students when they write on their own.

\subsection{Independent constructing}

After jointly constructing a text with their teacher in the given genre, students compose their own texts on a similar topic. During this stage, the teacher monitors the writing and helps students in the process. The final product may be produced in class or taken home as an assignment. 


\subsection{Revising and editing}

This is the time when students have the chance to revise and edit their first draft. Revision can be done by the teacher or by their peers under the guidance of the teacher. The teacher may choose to publish the work of students to give them a sense of achievement and motivate them to write more.

\subsubsection{Writing assessment}

The assessment of writing in L2 is an integral part of research on writing. This is because, as Tang (2012) explains, writing involves several factors that affect the learning and the production of writing. Writing assessment is as difficult as teaching writing because it involves different stages that are neither consecutive nor sequential. The studies of Li (2008), Myles (2002), and Allen and Katayama (2016) describe assessing writing as multi-layered, as it takes place at the cultural, cognitive, and L2 linguistic proficiency levels. It is an area that attracts academic attention, given its vital role in language learning. Like all language skills, writing assessment is an indicator of academic performance and the proficiency level in the target language. Measuring this indicator is easier said than done, which explains why this area of EFL research is continually growing. Such research incorporates different aspects of writing, such as grammar, organization, coherence, and other writing mechanics. Available literature in the field of writing assessment reveals three general approaches to this endeavor: diagnostic, formative, and summative.

\subsubsection{Diagnostic Assessment}

This type of assessment aims at diagnosing the students' writing strengths and weaknesses. According to Hyland (2007), diagnostic assessment guides learning, 
ameliorates teaching, and evaluates students' progress, which in turn enables teachers to revise and develop their teaching materials in light of the extent of progress. Diagnostic assessment in writing happens in the pre- and post-instruction stages. Jang (2009) states that in the pre-instruction stage, diagnostic assessment is in the form of a test to assess a student's prior knowledge. In other words, its purpose is to determine a baseline of the students' linguistic skills and knowledge. It can take place at the beginning of a course or at the beginning of each unit in a course. The results are then used to develop the teaching material accordingly. Instruction can have a remedial aspect, if needed. Following learning, students are given the same diagnostic test to measure the extent to which they have improved their writing skills. However, as Storch (2009) maintains, this type of assessment is flawed because it does not provide students with feedback about their writing strengths and weaknesses. Therefore, even if this type of assessment does improve the students' writing performance, it fails to point out the issues inherent in the process.

\subsubsection{Formative Assessment}

Unlike diagnostic assessment, formative assessment is based on feedback. Students receive feedback on their writing as a way of enhancing and accelerating the learning process. The potential of formative assessment in EFL writing instruction has been pointed out by several scholars. For example, Lee (2011) identifies a set of conditions that should be met to make formative assessment effective- the awareness of the need to change, on the part of teachers, the readiness of teachers to vary and develop their teaching practices, and the existence of a supportive system. Formative assessment rests on generating formative feedback for students from their teacher, peers, and computers, or even from the learners themselves. Kasanen and Räty (2002) highlight the importance of self-assessment as a common practice of formative 
assessment in the EFL context. They state that it judges, evaluates, and weighs the quality of the academic performance.

There is conflicting evidence in the literature about the effectiveness of Student Self-Assessment (SSA). For example, Panadero, Brown, and Courtney (2014) report that SSA is a positive experience. Their findings contrast with those of Belachew, Getinet, and Gashaye (2015) who identify some pitfalls on SSA. One is that students are not qualified to make an adequate and honest assessment of their own writingmost participants in their studies overestimated their writing performance. Another common practice of formative assessment is peer assessment. Wang (2014) suggests that this practice is widely used in L1 and L2 writing classes for the purpose of raising students' awareness of each other's mistakes and to learn from them. However, like all assessment methods, it comes with its own shortcomings. Wang (2014) points out that its effectiveness is undermined by factors like students' attitudes towards peer assessment and feedback, and their interpersonal relationships.

\subsubsection{Summative Assessment}

Summative assessment is another common method used in writing classes. Hyland (2004) defines it as 'any assessment concerned with summing up how much a student has learned by the end of a course' (p. 213). The goal of this method is to assess the achievement of learners at the end of a unit, course, or semester. In assessing writing performance, it usually weighs it against a global standard or benchmark. He and Shi (2008) argue that this method usually employs a 'high point value' and is performed under controlled conditions. Summative assessment comes in different formats, like mid-term and final exams, portfolios, end of chapter/unit tests, or standardized tests used in student admissions exams, such as GCSE and A-levels. Critics of this assessment method, such as Hailu and Rustaman (2012), argue that it is more diagnostic 
than remedial. It only surveys the learning styles of students and provides feedback to both teachers and learners.

\subsection{Blended Learning Context}

Blended learning has made its way into the EFL context. Educational institutions are implementing new technologies in their classes to stimulate learning and to create a favorable learning environment. While blended learning has become a reality in many higher institutions, it is still a novelty in many places around the world. Therefore, researchers are still investigating the potential of blended learning in EFL classrooms.

Friesen (2012) defines blended learning as an educational curriculum in which traditional classroom learning is blended with online material. This form of learning, according to Graham (2006), falls within the global trend moving away from a teachercentered approach to a learner-centered approach. This type of learning encourages the active participation of the learner through online materials, but the definition of blended learning seems to vary from one researcher to another. Blended learning can be implemented in different ways. Horn and Staker (2015) list several implementation models, including labs, self-blended, online drivers and face-to-face drivers. Regardless of the method of implementation, blended learning offers valuable benefits for learners. Wall and Ahmed (2008) argue that blended learning provides students with a dynamic and joint learning experience. Garrison and Kanuka (2004) maintain that this type of learning fosters achievement and brings satisfaction. The effectiveness of blended learning in achieving favorable learning outcomes has been pointed out by Poon (2013). This chapter reviews the implementation of blended learning and its effectiveness in the context of social media.

\subsubsection{Technology and Teaching Writing}


With the advent of technology and social media, approaches to teaching writing have evolved. According to Rahma et al. (2018), language learning has benefited enormously from technological advances and social media. These technologies provide language teachers and learners with valuable tools and opportunities to master language skills. Shirinbakhsh and Saeidi (2018) conclude that language teachers must face the challenge of incorporating new technologies and motivating students to use them to become self-learners.

Previous literature documents the effectiveness of technology in education, which can be traced back a few decades. In its initial stage, research set out to explore the potential of new technologies as teaching tools and the different methods of implementing them. Frigaard (2002) confirms the benefit of technology in language teaching as a way to boost students' achievements. Similarly, Mishra and Koehler (2006) and Timucin (2006) demonstrate the different ways technology can be implemented in the teaching of languages. Their studies focus on the role of computers and the internet to ameliorate students' work. More recent studies, such as Haswani (2014) and Ghavifekr and Rosdy (2015) address the attitudes of EFL teachers towards the implementation of technology in their classrooms as well as other related obstacles. Their findings suggest that the effectiveness of technology as a medium for teaching largely depends on the readiness of the teacher to embrace it. Otroshi and Bourdet (2012) stress the value of the teacher's knowledge of technology in the implementation process. Their results indicate that lack of knowledge of the appropriate technology is a major setback to embracing technology.

There seems to be a consensus in the literature that the adequate implementation of technology improves and increases learning opportunities. Behzadi (2015) concedes that technology offers valuable opportunities for language learners to develop and 
expand their skills. This is mainly because technology grants learners an individualized approach to language learning. Akele (2013) adds that technology provides good motivation in the EFL context. Motivation is a key factor in language learning, but traditional classrooms often lack the potential to motivate students, as Ghavifekr and Rosdy (2015) assert. However, technology alone is not enough to improve language learning. It should be used in parallel with traditional face-to-face learning. Technology transforms the learning environment and offers a more customized approach to learning.

The advent of the internet and the increasing popularity of social networks have brought about significant changes in language learning and teaching. New technologies are being implemented in classrooms to help students master the different language skills. For example, social networks have recently been used to improve the writing skills in L2. This came as a response to the difficulties EFL learners face in acquiring this skill. Part of the challenge stems from the fact that writing is still taught with traditional classrooms. The classroom setting, according to Al-Hammadi (2011), may be good for introducing students to the basics of writing, but they are not effective in handling learner differences. Writing includes many steps, such as formulating a good thesis statement, finding the right arguments to support it, and editing the final product. Al-Hammadi (2011) believes that these steps are too varied to be covered in traditional classrooms. Social media, thanks to their interactive nature, offer a good option able to cater to the different learning styles and to deal with these steps.

Mobile technology and social media have more recently been integrated into language teaching. Motaghian, Hassanzadeh, and Moghadam (2013) demonstrated that the use of social media is an effective way of connecting the processes of learning and teaching. In a similar vein, Qarajeh and Abdolmanafi (2015) pointed out that the use of 
social media applications in teaching has become widespread in many universities around the world. Nowadays, it has become customary to set up a WhatsApp or a Telegram group for every course through which students interact with their teachers regarding the course. Social networks can bolster formal learning and become integrated in the educational environment. Lee (2015) advocates the role of social networks, such as Twitter, Facebook, and Telegram, to facilitate online learning of English. These networks create an environment that, as Lee (2015) maintains, favors motivation, confidence, and positive attitudes towards language learning.

Social media offer teachers and learners a flexible and friendly platform where extra-curricular activities take place to enhance the learning process. For instance, AlJarf (2009) demonstrates that writing can be developed and improved through the use of such technologies as mind-mapping software. Allam and Elyas (2016) found that the opinions of teachers regarding the use of social media are divided-for many, the use of social media can motivate Saudi college students to learn writing, while for others the use of mobile phones and social media in the EFL context can be misused. Ahmed (2015) investigated the use of Twitter and concluded that it has great value in teaching writing to undergraduate students.

\subsubsection{WhatsApp}

WhatsApp is an instant messaging application ('app') frequently used for educational purposes. It offers the opportunity to create groups and to interact in real time at each member's convenience. Educators have turned their attention to this app with the hope of providing students an innovative learning experience. Research on the impact of WhatsApp has been burgeoning recently. To examine its effects on the lexical aspect of writing in the EFL context, Nedal and Hani (2014) carried out a journalingbased experiment on the app to measure the development of lexical accuracy in EFL 
learners. His findings suggest that this dialogue journaling on WhatsApp improves word choice and the writer's voice.

The effect of WhatsApp in improving writing and reading skills simultaneously has also been explored. Justina (2016) conducted an experiment on undergraduate EFL students to find out whether WhatsApp increases students' motivation to read and write. Her results indicate that this app increased students' interest and commitment to writing, because it made learning a personalized experience.

Students' engagement and incentive to learn language has been a major focus in connection with social media in general. A study carried out in 2014 by Tze, Dewika, and Devandran revealed the role of WhatsApp and Facebook in increasing the engagement and the motivation of EFL learners. They argue that social media have triggered students'interested in the content being taught. Der Vyver and Marais (2015) offer a different perspective on the use of WhatsApp in teaching languages, stating that it serves as a good classroom management tool. Their findings indicate that this application can be a good communication harbor outside the classroom. In a similar vein, Andújar-Vaca and Cruz-Martínez (2017) explored the potential of WhatsApp to improve oral communication skills of EFL learners. Their study revealed that WhatsApp enhances the fluency of oral communication. They explain their findings by arguing that this instant messaging application creates an environment in which students can negotiate meaning and self-evaluate their performance. This selfevaluation is realized through genuine interaction with their peers and instructor.

WhatsApp messenger was also used in writing classes. Ghada (2016) experimented with implementing WhatsApp to improve the proficiency of students' writing. Through the observation of a control group, she concluded that WhatsApp not only improved the students' writing proficiency but also positively changed their 
perception of writing. Nedal and Hani (2014) investigated the role of WhatsApp in ameliorating students' lexical accuracy. Using a pre-test and a post-test, they demonstrated that there is a positive correlation between the use of WhatsApp and advanced lexical complexity among learners. Moreover, they advocates the use of journaling on WhatsApp to enhance voice-writing skills. The use of WhatsApp to teach vocabulary has also been studied. Chuah (2014) provides empirical evidence that WhatsApp has helped students learn and use academic words.

\subsubsection{Blackboard}

The appearance of Learning Management Systems (LMS), such as Blackboard, is a major leap forward in the field of blended learning. The interactive nature of such systems makes their application in EFL classes easy and promising. The Blackboard system has been the subject of academic research for many years. Liaw (2008) contends that Blackboard has a direct impact on EFL learners, because it gives them the opportunity to receive constructive feedback from their peers and instructor. Blackboard is a flexible learning tool that provides educators and learners with a variety of activities. This point was highlighted by Servonsky, Daniels, and Davis (2005) who argue that Blackboard offers students synchronous activities (chat rooms) and asynchronous tasks (drop boxes, discussion boards). These activities increase learnerto-learner and learner-to-instructor interactions. Interaction between learners and instructors is, according to Liaw (2008), essential to optimize the satisfaction of learners and improve motivation. Liaw's study highlights the importance of self-efficacy as brought about by LMS.

Research on Blackboard has focused on its usefulness as a learning tool. The findings in extant literature are varied and sometimes contradictory. One study conducted by Chang, in 2014, revealed that students and instructors have differing 
perceptions of Blackboard's usefulness, which affects the behavioral intention of learners to engage in and use it. The study was carried out in English classes offered to undergraduate business students. The validity of their findings lies in the way they correlated students' intention to use Blackboard with its perceived usefulness. The role of perceived usefulness in the use of Blackboard was confirmed by Sun, Tasi, Finger, Chen, and Yeh (2008) also. Their study correlates perceived usefulness with learners' satisfaction. The results indicate that students with a positive perception of its usefulness are more likely than their peers to be satisfied with blended learning. Similarly, Larkin and Belson (2005) maintained that EFL learners develop attitudes towards Blackboard learning, and these attitudes greatly affect their learning outcomes.

The use of Blackboard in the EFL context is particularly interesting due to the interactive nature of language learning. Tella (2012) state that, since the development of any language skill is based on interaction, Blackboard is an effective learning tool. Mouakket and Anissa (2015) studied the role of discussion boards on the development of communication skills for EFL learners. Their findings reveal that Blackboard eases the stress and anxiety that some students experience in face-to-face discussion. This, in turn, makes students more comfortable in the target language. While their study stresses the benefits of Blackboard, it maintains that such benefits are contingent on the teacher's attitude towards this learning tool. Students need a positive attitude towards Blackboard to implement it appropriately. Al Zumor, AlRefaai, Eddin, and Al-Rahman (2013) report that the use of Blackboard positively affects learning reading and writing skills. According to a study done in Saudi Arabia in 2007 by Bulut and AbuSeileek, EFL students find Blackboard to be more successful in learning listening than in the other language skills. 
In conclusion, it can be argued that Blackboard has become an essential part of language teaching in recent decades. The interactive nature of this LMS has made it particularly suitable in the EFL context. The literature available shows that the usefulness of this LMS depends on a number of factors, such as perceived usefulness and the attitudes of learners and instructors.

\subsubsection{Telegram}

Telegram is now emerging as both an effective educational tool in the field of language learning and as a research topic. The growing popularity of Telegram as a learning tool can be explained by its potential to improve academic performance. This potential has been investigated in many recent studies. For instance, Badri (2015) claims that Telegram gives students the option to store an unlimited number of messages which they can later retrieve and consult. Moreover, as Ghaemi and Golshan (2017) have shown, the importance of Telegram lies in its attractive audio-visual features that keep users engaged.

Likewise, Heidar and Kaviani (2016) stress the importance of the audio-visual features of this application. In their opinion, Telegram is a particularly effective tool to learn English, because it can be used on mobile devices as well as computers, and because it supports audio-visual features. Aghajani and Adloo (2018) assert that Telegram improves overall writing performance, in terms of content, language, and structure. It was also found by Heidar and Kaviani (2016) that Telegram offers EFL learners a unique opportunity to develop their vocabulary online. According to Shirinbakhsh and Saeidi (2018), Telegram has a positive impact on students' motivation to learn reading. Rahma et al. (2018) argue for the positive influence Telegram has on learning writing. 
The flexibility of Telegram is one of the key features driving its growing popularity in EFL education. Iksan and Saufian (2017) affirm that the application has some astounding interactive features that enhance creativity in language learning. These features include discussions, drawing techniques, and audio-visual tools. The use of these techniques outside the classroom, according to their study, encourages students to create spontaneous and original ideas without fear of ridicule. The findings of this study are in line with that of Alkhezzi and Al-Dousari (2016) who established a positive correlation between the use of Telegram interactive tools and learners' understanding of new vocabulary items and grammar rules. The advantages of using Telegram in the teaching of English vocabulary were also studied by Xodabande (2017) who demonstrated that Telegram improves learners' pronunciation.

An EFL study carried out by Nabati (2018) explored the benefits of Telegram on students' writing accuracy and grammar. The 20 participants were given writing instructions and grammar points exclusively through Telegram. The results showed that the students' accuracy improved markedly on the post-test. Sarvari and Ezzati (2019) made a similar attempt to determine the role of Telegram in teaching writing in an EFL context. Their study included 46 EFL learners who were taught writing through Telegram for eight weeks. The results showed significant improvement in the overall writing performance of the participants.

Based on the available literature, the use of Telegram in EFL classrooms is steadily increasing, but research on its use in academic fields is still in its infancy. For instance, Yinka and Queendarline (2018) conducted research through the use of a questionnaire filled out by 300 college students at the University of Port Harcourt, Rivers State. Their study targeted students of different disciplines, including the humanities, curricula, and education. The major findings of the study were that 
Telegram is capable of being a valuable extension of classroom activities. Nevertheless, the impact of Telegram on syntactic complexity of EFL learners is still under-studied.

This study seeks to fill in this gap in the literature by investigating this aspect specifically and to contribute to the discussion of using Telegram to develop syntactic complexity within the Saudi context. The strength of the study lies in the fact that it will provide empirical data on how the use of Telegram may affect the writing complexity of EFL students. It differs from previous studies in two aspects. First, the research will include both an experimental group and a control group, totaling 48 students. This will allow comparisons of the writing skills reflected by post-testing between the two groups, which will help validate the hypothesis. Second, this study will target one area of writing: syntactic complexity. The development of students' performance in one specific field of writing can be assessed more meaningfully than their overall writing skill.

\subsection{Assessing Complexity, Accuracy, and Fluency (CAF)}

In learning a foreign language, one of the fundamental skills required is writing. According to most researchers, the critical aspects of L2 writing performance can be evaluated by learners' mastery of accuracy, fluency, and complexity in communicating at the level expected from a person who understands the language. Fluency measures the level of comfort of the learner in producing language, while accuracy denotes the ability of the learner to communicate, either through speech or writing, without linguistic errors. Complexity, on the other hand, is structured into two components: grammatical and lexical. Grammatical complexity refers to the availability of a wide variety of sophisticated and basic structures in the language construct, while lexical complexity denotes the quick access of sophisticated and basic words in the learner's 
language construct. Given these definitions, the three attributes together measure the overall development of a learner.

Three approaches have been taken by researchers in analyzing EFL writing in secondary education. Some have adopted the cross-sectional approach, others took the longitudinal approach, and some utilized the dynamic method. Researchers using the cross-sectional approach include Yang, Lu, and Weigle (2015) and Lorenzo and Rodriguez (2014). Lorenzo and Rodriguez (2014) used formal bilingual contexts as the basis for understanding the evolution and appearance of language structures in secondlanguage academic writing. The target area for Lorenzo and Rodriguez (2014) was the historical narratives of third-year secondary education respondents to second-year postcompulsory secondary education. The study applied complex nominals per clause, coordinated phrases per clause, mean length of clause, and verb phrases per T-unit as complexity measures for analysis.

Other complexity measures included dependent clauses per clause, clauses per sentence, dependent clauses per T-unit, and complex nominals per T-unit. In analyzing lexical complexity, the study utilized twenty-five different measures, which included lexical range, verb sophistication, different parts-of-speech variations, and ratios of diverse type-token. The results from the analysis indicated that an amalgamated language was produced by learners who were in the lowest grades, although their language had a characteristic deficiency of dependent clauses, coordinated phrases, and T-units. With improvement in the examined measures, this skill in language became dominant in the learners with higher grades. The results also revealed that even though the changes were recognizable and continuous according to grades, they were unstable. The uppermost course had higher peaks of significant instability levels. 
The study by Yang et al. (2015) addressed the cross-sectional approach through a multi-dimensional construct in which the focus was on syntactic complexity. One of the areas examined by their study was the relationship between writing quality and syntactic complexity in ESL writing. The study also considered the role of topic in the relationship. As part of the study, one of the activities conducted by ESL graduate students participating in the research was to use two different topics to write two argumentative essays. The authors subsequently used the mean length of T-unit and length of sentences to measure syntactic complexity. Their results revealed that syntactic complexity was significant in predicting writing scores of the participants in the two topics.

The longitudinal approach in analyzing EFL writing in secondary education featured in the studies by Knoch, Rouhshad, and Storch (2014), Knoch, Rouhshad, Oon, and Storch (2015), Godfrey, Treacy, and Tarone (2014), and Naves, Torras, and Celaya (2003). The study by Knoch et al. $(2014,2015)$ revealed that there was notable writing development, but its measures were limited to students who had studied abroad for some time. The studies by Naves et al. (2003) and Godfrey et al. (2014) used the longitudinal approach but expanded their scope to include a comparison of different groups' performances. In the case of Naves et al. (2003), the study used complexity, fluency, and accuracy measures to investigate the development of written production in six groups of secondary and primary education learners. Eight measures were used to assess fluency, including the total number of sentences, the total number of clauses, and the total number of words. On accuracy, the study considered the quantity of rejected units, the percentage of sentences that were free from error, and the number of sentences that were error-free. 
Accuracy was measured using twenty-seven features that included the ratio of clauses per sentence, the number of coordinated clauses, and the number of subordinate clauses. The finding of the study was that in EFL written production, the learner's age determined the pattern of development. The other significant finding was that there was no similarity in the development of fluency, accuracy, and lexical and syntactic complexity. However, the development of the four correlated according to age group of the learners and the relationship strength of the four components. The study by Godfrey et al. (2014) included eight university learners and measured the four components that were of concern to Naves et al. (2003). The eight learners were divided into two groups - those who studied abroad and others who studied on-campus. The results showed that there was considerable progress in the two groups of students, though in different ways, on advanced L2 academic writing.

The dynamic approach to analyzing EFL writing in secondary education featured in the studies by Thewissen, (2013), Rosmawati (2014), and Larsen-Freeman (2006, 2012). The studies by Rosmawati (2014) and Larsen-Freeman $(2006,2012)$ found a high degree of fluctuations and variability among the respondents, and significant improvement in the groups that took part in the study. The reason the approaches in these studies are considered dynamic is because of the constructs of complexity, affluence, and fluency, whose expression of development must reflect non-linear growth and a high degree of variability. The studies by Thewissen (2013) and Rosmawati (2014) had similar results on the degree of variability and non-linear growth of the participants in writing production.

The literature reviewed demonstrates that over time and across levels of proficiency, there is significant improvement in written production as revealed by the 
written competency assessment measures. The studies further showed that, as proficiency increases, the number of errors in writing declines. 


\section{Chapter Three}

\section{Methodology}

\subsection{Introduction}

This chapter presents the problem statement, the research design, and an explanation of the methodology used in this thesis, including the setting and the participants recruited. The discussion of the methodology will include the courses in which the experiment was carried out, followed by a discussion of the teaching methodology and the teaching/learning contexts, the materials, the data collection procedures, and the ethical considerations. The chapter ends with a discussion of the data analysis methods.

\subsection{Statement of the Problem}

This thesis seeks to study the impact of Telegram on developing syntactic complexity among Saudi EFL students in an attempt to shed some light on the differences between blended and traditional EFL contexts insofar as syntactic complexity is concerned. Toward that end, the thesis investigated the following research questions:

1. Did the control group's syntactic complexity increase/decrease for the three writing tasks (argumentation, classification, and reaction) as a whole and/or across specific measures?

2. Did the experimental group's syntactic complexity increase/decrease for the three writing tasks (argumentation, classification, and reaction) as a whole and/or across specific measures? 
3. Did the experimental group outperform the control group in syntactic complexity when writing argumentation, classification, and reaction texts and, if so, to what extent?

\subsection{Research Design}

The research adopts an exploratory - experimental quantitative research design to investigate the impact of Telegram on the development of written syntactic complexity of EFL Saudi university students. The exploratory research design is appropriate when the aim of the study is to gain new insights or to evaluate an emerging or existing phenomenon in a new light (Dennen, Darabi \& Smith, 2007). The use of Telegram in ELF classrooms is a relatively new phenomenon, which needs to be evaluated. The exploratory research design is highly flexible and allows researchers to formulate problems, gather information and discard irrelevant ideas (Saunders, Lewis, and Thornhill, 2012). The exploratory research method was selected due to its flexibility and its potential to lay the groundwork to inspire future studies on the topic.

Researchers working with an exploratory research design may face a major obstacle. The research design tends toward the qualitative, mainly because it deals with something novel. According to Brown (2006), an exploratory research design is never complete unless it employs both qualitative and quantitative research methods consecutively. To overcome this obstacle, the thesis has incorporated an experimental quantitative design in its approach to the topic. In other words, the exploration of the effects of Telegram on students' syntactic complexity would not have been possible without controlling one of the variables. Therefore, the researcher has opted for experimental quantitative research. Experimental research designs allow for the manipulation of one of the variables, while controlling the changes in the other variables (Singh, 2007). 


\subsection{Research Setting}

The study was carried out at the College of Languages and Translation at Imam Muhammad Bin Saud Islamic University in 2019 during ten weeks of the fall semester. The experiment targeted students of the English department at this college in the female section only. The recruited students were selected, instructed and tested in the same location.

\subsection{Participants}

The recruited participants were from level six who had finished the five prior writing courses at the college. There was a total of forty eight students in the study. The participants were randomly and unevenly divided into the control and experimental groups. The control group consisted of 28 students; while the experimental group was comprised of 20 students. For greater reliability, the population of this study contained students of various academic levels.

\subsection{EFL Courses}

This experiment was carried out during the fall semester of the 2019-2020 academic year. At the time of the study, level-six students were enrolled in a writing class called Essay Writing (ENG 316). The contact hours for this class were two hours per week. The course is mandatory for level-six students and its pre-requisite in the study plan is Essay Writing (ENG 315). The required textbook for the course is Effective Academic Writing, by Jason Davies and Rhonda Liss (2016). This textbook covers various aspects of academic writing, such as the five-paragraph essay, process analysis essays, cause and effect essays, argumentative essays, classification essays, and reaction essays. Even though the content of the textbook aligns well with the objectives of this research, the researcher provided the participants with additional materials on the argumentative, the classification, and the reaction essays to further 
enhance their understanding. These materials were distributed in the first meeting with the participants in both groups (the experimental and the control). However, the experimental group benefited from additional lectures on Telegram relating to these essays. The extra lectures on Telegram focused mainly on the organization of the essays, formulating a thesis and topic sentence, and several language points.

\subsection{Teaching Methodology, Teaching/Learning Contexts, and Participants}

The designated writing textbook mandated by the college is "Effective Writing 3" by Jason Davis and Rhonda Liss. Level-6 participants are only required to take the last three chapters (Argumentative essays, Classification essays, and Reaction essays). The teaching approach for writing applied to all the participants was the process genre approach. This approach requires students to analyze teacher-provided sample texts on argumentative, classification and reaction essays written by professional writers. In our study, students were required to write multiple drafts - each to be corrected by the teacher and the students' peers - for each of the topics they are assigned. Although both the control and the experimental groups were taught in traditional classrooms, only the experimental group was asked to complete further requirements via Telegram software. They received orientation on how to access and use Telegram.

\subsubsection{Traditional learning context group}

The control group consisted of 28 female students being taught by their regular instructor. There was no experiment for this group. Students in this group were not added to the Telegram group. The class instructor introduced me to the students and allowed me to lecture them for one class period. The researcher introduced this research to the students and explained the goals of the experiment. The lecture then focused on introducing students to the different types of essays that were covered in the research. 
The students were then given handouts regarding the 14 points of syntactic complexity. These included: length of sentence, length of T-unit, length of clause, clauses per sentence, verb phrase per T-unit, clauses per T-unit, dependent clauses per clause, dependent clauses per T-unit, T-units per sentence, complex T-unit ratio, coordinate phrases per T-unit, coordinate phrases per clause, complex nominals per T-unit, and complex nominals per clause.

At the beginning of the experiment, the participants had little or no idea of these types of essays. The researcher explained the components of these essays to the students before the pretest. This group was given the same pretest and posttest as the experimental group. The pretest was then conducted in a period of three hours. It consisted of one essay question for each of the three essay types discussed above (see Appendix A for the pretest essay questions). For the rest of the experiment, this group continued to be instructed in a traditional classroom setting by their teacher who followed the process-genre approach in her classes. At the end of the experiment, these students were given a posttest that was similar in structure to the pretest. To avoid the issue of familiarization, which is known to affect outcomes, the essay questions in the posttest were different from those on the pretest (see Appendix B for the posttest essay questions).

\subsubsection{Blended learning context group}

The experimental group consisted of 20 female students being taught by their regular instructor. The experiment was conducted on Telegram. Therefore, this group benefited from traditional classroom instruction on writing with their instructor and from the Telegram-based teaching. As with the control group, The researcher took advantage of the first meeting to introduce students to this research and the experiment. The lecture was centered on introducing the students to Telegram, helping them set up 
their own Telegram accounts, and explaining its various features. By the end of the lecture, a Telegram group had been created and all the students were successfully added to the group. As with the control group, the lecture with this group concluded with an explanation of the 14 points of syntactic complexity that the research seeks to develop. The students were informed that their writing on Telegram will be monitored through discussion, interaction, and real-time feedback.

A number of lectures were delivered on Telegram that focused on crucial areas of essay writing, such as essay planning, formulating a thesis statement, writing an introduction, writing the conclusion, organizing the body paragraphs, drafting topic sentences, using cohesive devices, capitalization, and coherence. After two weeks of the experiment, some participants raised questions about syntactic complexity and how it can be achieved. In response, the researcher devoted the beginning of each lecture to explain the 14 measures of syntactic complexity mentioned above.

\subsection{Materials and procedures for data collection}

\subsubsection{Materials: Writing Essays}

The participants in this study were asked to write essays. The experiment targeted three types of essays: the argumentative essay, the classification essay, and the reaction essay. In each case, students were asked to write a six-paragraph essay, with a total of 250 words. The essay questions were taken from English language proficiency tests, such as IELTS and TOFEL, and from widely-approved writing textbooks.

\subsubsection{Procedures}

Before the experiment started, the researcher completed all the necessary formalities to obtain permission from the university. Once approval was received, the 
researcher arranged a meeting with the course instructor. During this meeting, the researcher explained the research objectives, the research tools, and the expected outcomes. To facilitate the experiment, the instructor explained the course syllabus and the activities planned. Before the semester started, the researcher had planned everything in advance. The additional materials were handed to the course instructor for revision and approval. After a series of meetings, the researcher agreed with the course instructor to divide the participants into the control and the experimental groups and to hold a face-to-face lecture with both groups. The face-to-face lecture was held during the second week of the semester (after the Add/Drop period) to ensure that the number of students would not change. During the first week of the semester, students met their regular instructor who introduced them to the syllabus and the textbook, as well as the class schedule. In the second week, the experiment began.

In the first meeting with the participants, the researcher introduced the students to this research and explained the procedures of the experiment to them. For both groups, the first lecture focused on a discussion of the three types of essays to be included in the experiment. At the end of this face-to-face lecture, the pretest exam was given to the participants. Students sent their answers via email. After this lecture, the control group continued with their teacher for the remainder of the experiment, while the experimental group benefited from a number of lectures on Telegram at an average pace of one lecture per week. In addition to these lectures, there were several discussions on syntactic complexity, essay organization, and other aspects of writing. At the end of the tenth week, both groups took the posttest. As with the pretest, students sent their answers via email. 


\subsection{Ethical Considerations}

This research was conducted in accordance with the ethical standards in line with the nature of the project. Permission was obtained from the Al-Imam Muhammad Ibn Saud Islamic University prior to beginning the experiment. Oral informed consent was obtained from participants in the female section, at the beginning of the study. The researcher met with participants, explained the objectives of the research, the data collection and analysis methods and how the results will be used. Participants were assured of confidentiality and that the data they provide will not be shared with any third party.

\subsection{Data Analysis}

The main research tools of the thesis were a pre and a post-test. The same tests were given to the control and the experimental groups. Each test consisted of three essay questions. To analyze the writing samples, the research made use of L2 Syntactic Complexity Analyzer (L2 SCA) software designed by Xiaofei Lu. The software supports fourteen different measures. Because the use of this software requires knowledge of Python, the researcher will use the online version developed by Professor Aihauyang to measure the results of the experiment. Previous studies have verified the reliability of the software as a tool for evaluating syntactic and lexical complexities (Wind, 2013). For example, Alghizzi (2017) demonstrated that both manual and software analyses of syntactic structure led to the same conclusions.

To achieve the thesis goals, two t-tests were carried out: a paired t-test and an independent samples t-test. The researcher conducted the paired t-test first to compare pre- and post-test findings for each of the fourteen syntactic complexity measures in the two different learning contexts. This was to determine if student performance in those measures was affected similarly or differently by the three writing tasks 
(argumentation, classification and reaction). The t-test was applied accordingly to each task pre- and post-test. The analysis compared the data either partially (across each measure) or fully (through the mean average of the pre- and post-tests). The results of these comparisons helped classify them in terms of effect (unaffected, increasing, decreasing, or both). The independent samples t-test was conducted subsequently to determine which learning context led to the greatest increase or decrease in syntactic complexity either partially or fully. The mean average of the post test was subtracted from the mean average of the pretest, in this comparison. 


\title{
Chapter Four
}

\section{Results}

\begin{abstract}
4.1. Introduction
This chapter presents results measuring the syntactic complexity of the control and experimental groups individually and together for the three text types (argumentation, classification, and reaction).
\end{abstract}

\subsection{Syntactic Complexity of Saudi Participants}

This study had a control group and experimental group. Both groups were given a pre- and post-test where they were asked to write an argumentation, classification, and reaction essay. Student responses were analyzed in view of fourteen measures of syntactic complexity. The study made two types of comparison. First, a paired t-test was carried out to see the changes across each measure in the pretest and the post-test and also to compare the whole mean average in the pre-test and the post-test. Second, the two groups were compared together through an independent t-test to see whether syntactic complexity has increased/ decreased. In this comparison, the mean average of the post test was subtracted from the mean average of the pretest.

\subsection{Syntactic complexity of the control group}

\subsubsection{Syntactic Complexity of the control group in the Argumentative Essay}

Table 1 presents the comparison results for the control group's syntactic complexity drawn from the argumentative texts. 
Table 1:The Comparison Results of the Control Group's Syntactic Complexity in Argumentative Texts.

\begin{tabular}{|c|c|c|c|c|c|}
\hline $\begin{array}{l}\text { Syntactic } \\
\text { Complexity } \\
\text { Measures }\end{array}$ & Tests & $\mathrm{N}$ & Mean & $\begin{array}{l}\text { Standard } \\
\text { deviation }\end{array}$ & P-value \\
\hline $\begin{array}{l}\text { MLS=length of } \\
\text { sentence }\end{array}$ & $\begin{array}{l}\text { Pre -Test } \\
\text { Post -Test }\end{array}$ & 28 & $\begin{array}{l}19.58 \\
19.26\end{array}$ & $\begin{array}{l}5.84 \\
6.25\end{array}$ & 0.60 \\
\hline $\begin{array}{l}\text { MLT=length of T } \\
\text { unit }\end{array}$ & $\begin{array}{l}\text { Pre -Test } \\
\text { Post -Test }\end{array}$ & 28 & $\begin{array}{l}17.18 \\
17.41\end{array}$ & $\begin{array}{l}5.10 \\
5.52\end{array}$ & 0.61 \\
\hline $\begin{array}{l}\text { MLC=length of } \\
\text { clause }\end{array}$ & $\begin{array}{l}\text { Pre -Test } \\
\text { Post -Test }\end{array}$ & 28 & $\begin{array}{l}9.80 \\
9.86\end{array}$ & $\begin{array}{l}1.94 \\
1.72\end{array}$ & 0.75 \\
\hline $\begin{array}{l}\mathrm{C} / \mathrm{S}=\text { clauses per } \\
\text { sentence }\end{array}$ & $\begin{array}{l}\text { Pre -Test } \\
\text { Post -Test }\end{array}$ & 28 & $\begin{array}{l}2.04 \\
1.99\end{array}$ & $\begin{array}{l}0.65 \\
0.66\end{array}$ & 0.52 \\
\hline $\begin{array}{l}\mathrm{VP} / \mathrm{T}=\text { verb phrase } \\
\text { per T unit }\end{array}$ & $\begin{array}{l}\text { Pre -Test } \\
\text { Post -Test }\end{array}$ & 28 & $\begin{array}{l}2.30 \\
2.34\end{array}$ & $\begin{array}{l}0.47 \\
0.51\end{array}$ & 0.56 \\
\hline $\mathrm{C} / \mathrm{T}=$ clause per Tunit & $\begin{array}{l}\text { Pre -Test } \\
\text { Post -Test }\end{array}$ & $\begin{array}{l}28 \\
28\end{array}$ & $\begin{array}{l}1.71 \\
1.73\end{array}$ & $\begin{array}{l}0.36 \\
0.35\end{array}$ & 0.72 \\
\hline $\begin{array}{l}\mathrm{DC} / \mathrm{C}=\text { dependent } \\
\text { clause per clause }\end{array}$ & $\begin{array}{l}\text { Pre -Test } \\
\text { Post -Test }\end{array}$ & 28 & $\begin{array}{l}0.37 \\
0.40\end{array}$ & $\begin{array}{l}0.09 \\
0.14\end{array}$ & 0.31 \\
\hline $\begin{array}{l}\mathrm{DC} / \mathrm{T}=\text { dependent } \\
\text { clause per } \mathrm{T} \text { unit }\end{array}$ & $\begin{array}{l}\text { Pre -Test } \\
\text { Post -Test }\end{array}$ & 28 & $\begin{array}{l}0.75 \\
0.81\end{array}$ & $\begin{array}{l}0.49 \\
0.67\end{array}$ & 0.36 \\
\hline $\begin{array}{l}\mathrm{T} / \mathrm{s}=\text { Tunit per } \\
\text { sentence }\end{array}$ & $\begin{array}{l}\text { Pre -Test } \\
\text { Post -Test }\end{array}$ & 28 & $\begin{array}{l}1.11 \\
1.10\end{array}$ & 0.13 & 0.76 \\
\hline $\begin{array}{l}\mathrm{CT} / \mathrm{T}=\text { ComplexTunit } \\
\text { ratio }\end{array}$ & $\begin{array}{l}\text { Pre -Test } \\
\text { Post -Test }\end{array}$ & 28 & 0.47 & 0.13 & 0.97 \\
\hline & Pre -Test & 28 & 0.63 & 0.29 & 0.74 \\
\hline
\end{tabular}




\begin{tabular}{|c|c|c|c|c|c|}
\hline $\begin{array}{l}\mathrm{CP} / \mathrm{T}=\text { coordinate } \\
\text { phrase per Tunit }\end{array}$ & Post -Test & 28 & 0.62 & 0.27 & \\
\hline $\mathrm{CP} / \mathrm{C}=$ coordinate & Pre -Test & 28 & 0.38 & 0.20 & \multirow[t]{2}{*}{0.69} \\
\hline phrase per clause & Post -Test & 28 & 0.37 & 0.17 & \\
\hline \multirow{2}{*}{$\begin{array}{l}\mathrm{CN} / \mathrm{T}= \\
\text { complexnominals }\end{array}$} & Pre-Test & 28 & 2.06 & 0.54 & \multirow{2}{*}{0.20} \\
\hline & Post -Test & 28 & 2.17 & 0.53 & \\
\hline $\mathrm{CN} / \mathrm{C}=$ complex & Pre-Test & 28 & 1.23 & 0.31 & \multirow[t]{2}{*}{0.27} \\
\hline nominals per clause & Post -Test & 28 & 1.28 & 0.25 & \\
\hline \multirow{2}{*}{$\begin{array}{l}\text { Syntactic } \\
\text { Complexity as a } \\
\text { whole }\end{array}$} & Pre -Test & 28 & 59.64 & 13.22 & \multirow[b]{2}{*}{0.89} \\
\hline & Post -Test & 28 & 59.83 & 14.90 & \\
\hline
\end{tabular}

Across all syntactic complexity measures (i.e., MLS, MLT.MLC.C/S, VP/T, C/T, $\mathrm{DC} / \mathrm{C}, \mathrm{DC} / \mathrm{T}, \mathrm{T} / \mathrm{S}, \mathrm{CT} / \mathrm{T}, \mathrm{CP} / \mathrm{T}, \mathrm{CP} / \mathrm{C}, \mathrm{CN} / \mathrm{T}, \mathrm{CN} / \mathrm{C}$ ), there were no statistically significant differences between each measure's mean in the pre- and post-tests. Correspondingly, no statistically significant differences were found between the total means of all measures, indicating the syntactic complexity of the Saudi undergraduate EFL did not significantly increase or decrease in any measurable way during the argumentative essay. Figure 1 presents the comparison results expressing syntactic complexity as a whole for argumentative essay.

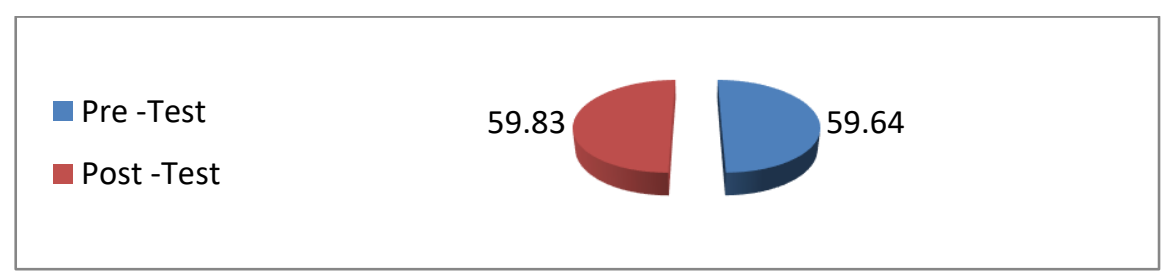

Figure 1:Control Group's Syntactic Complexity Results as a whole for Argumentative Essay. 


\subsubsection{Syntactic Complexity of the control group in the Classification Essay}

Table 2 presents the comparison results for the control group's syntactic complexity drawn from the classification texts.

Table 2:The Comparison Results of the Control Group's Syntactic Complexity in the Classification Texts.

\begin{tabular}{|c|c|c|c|c|c|}
\hline $\begin{array}{l}\text { Syntactic Complexity } \\
\text { Measures }\end{array}$ & Tests & $\mathrm{N}$ & Mean & $\begin{array}{l}\text { Standard } \\
\text { deviation }\end{array}$ & P-value \\
\hline \multirow[b]{2}{*}{ MLS=length of sentence } & Pre -Test & 28 & 18.62 & 6.63 & \multirow[t]{2}{*}{0.25} \\
\hline & Post -Test & 28 & 20.07 & 6.64 & \\
\hline \multirow[b]{2}{*}{ MLT=length of $\mathrm{T}$ unit } & Pre -Test & 28 & 17.35 & 5.96 & \multirow[t]{2}{*}{0.29} \\
\hline & Post -Test & 28 & 18.76 & 5.97 & \\
\hline \multirow[b]{2}{*}{ MLC=length of clause } & Pre -Test & 28 & 10.17 & 1.81 & \multirow[t]{2}{*}{0.18} \\
\hline & Post -Test & 28 & 10.69 & 1.51 & \\
\hline \multirow{2}{*}{$\begin{array}{l}\mathrm{C} / \mathrm{S}=\text { clauses per } \\
\text { sentence }\end{array}$} & Pre -Test & 28 & 1.87 & 0.74 & \multirow[t]{2}{*}{0.90} \\
\hline & Post -Test & 28 & 1.88 & 0.61 & \\
\hline \multirow{2}{*}{$\begin{array}{l}\mathrm{VP} / \mathrm{T}=\text { verb phrase per } \mathrm{T} \\
\text { unit }\end{array}$} & Pre -Test & 28 & 2.94 & 1.05 & \multirow[t]{2}{*}{0.73} \\
\hline & Post -Test & 28 & 2.88 & 0.75 & \\
\hline \multirow[b]{2}{*}{$\mathrm{C} / \mathrm{T}=$ clause per Tunit } & Pre -Test & 28 & 1.74 & 0.69 & \multirow[t]{2}{*}{0.72} \\
\hline & Post -Test & 28 & 1.71 & 0.44 & \\
\hline \multirow{2}{*}{$\begin{array}{l}\mathrm{DC} / \mathrm{C}=\text { dependent clause } \\
\text { per clause }\end{array}$} & Pre -Test & 28 & 0.36 & 0.12 & \multirow[t]{2}{*}{0.69} \\
\hline & Post -Test & 28 & 0.37 & 0.13 & \\
\hline \multirow{2}{*}{$\begin{array}{l}\mathrm{DC} / \mathrm{T}=\text { dependent clause } \\
\text { per } \mathrm{T} \text { unit }\end{array}$} & Pre -Test & 28 & 0.68 & 0.54 & \multirow[t]{2}{*}{0.81} \\
\hline & Post -Test & 28 & 0.70 & 0.44 & \\
\hline \multirow[b]{2}{*}{$\mathrm{T} / \mathrm{s}=$ Tunit per sentence } & Pre -Test & 28 & 1.07 & 0.09 & \multirow[t]{2}{*}{0.92} \\
\hline & Post -Test & 28 & 1.08 & 0.11 & \\
\hline
\end{tabular}




\begin{tabular}{|c|c|c|c|c|c|}
\hline $\mathrm{CT} / \mathrm{T}=$ ComplexTunit & Pre -Test & 28 & 0.45 & 0.19 & \multirow[t]{2}{*}{0.66} \\
\hline ratio & Post -Test & 28 & 0.47 & 0.22 & \\
\hline \multirow{2}{*}{$\begin{array}{l}\mathrm{CP} / \mathrm{T}=\text { coordinate phrase } \\
\text { per Tunit }\end{array}$} & Pre -Test & 28 & 0.55 & 0.31 & \multirow[t]{2}{*}{0.06} \\
\hline & Post -Test & 28 & 0.70 & 0.44 & \\
\hline \multirow{2}{*}{$\begin{array}{l}\mathrm{CP} / \mathrm{C}=\text { coordinate phrase } \\
\text { per clause }\end{array}$} & Pre -Test & 28 & 0.33 & 0.18 & \multirow[t]{2}{*}{0.16} \\
\hline & Post -Test & 28 & 0.38 & 0.17 & \\
\hline \multirow{2}{*}{$\begin{array}{l}\mathrm{CN} / \mathrm{T}=\text { complexnominals } \\
\text { per T unit }\end{array}$} & Pre -Test & 28 & 2.03 & 0.97 & \multirow[t]{2}{*}{0.58} \\
\hline & Post -Test & 28 & 2.14 & 0.91 & \\
\hline \multirow{2}{*}{$\begin{array}{l}\mathrm{CN} / \mathrm{C}=\text { complex } \\
\text { nominals per clause }\end{array}$} & Pre -Test & 28 & 1.18 & 0.33 & \multirow[t]{2}{*}{0.59} \\
\hline & Post -Test & 28 & 1.21 & 0.26 & \\
\hline \multirow{2}{*}{$\begin{array}{l}\text { Syntactic Complexity as } \\
\text { a whole }\end{array}$} & Pre -Test & 28 & 59.35 & 16.82 & \multirow{2}{*}{0.26} \\
\hline & Post -Test & 28 & 63.04 & 16.09 & \\
\hline
\end{tabular}

The comparison of means for each syntactic complexity measure, given pre- and post-test results, indicated no statistically significant differences. The same was true regarding the total means comparison, signaling that the syntactic complexity of the control group of Saudi EFL did not increase or decrease either partially across specific measures or fully when writing the classification essay. Figure 2 shows the comparison results expressing syntactic complexity as a whole for classification essay.

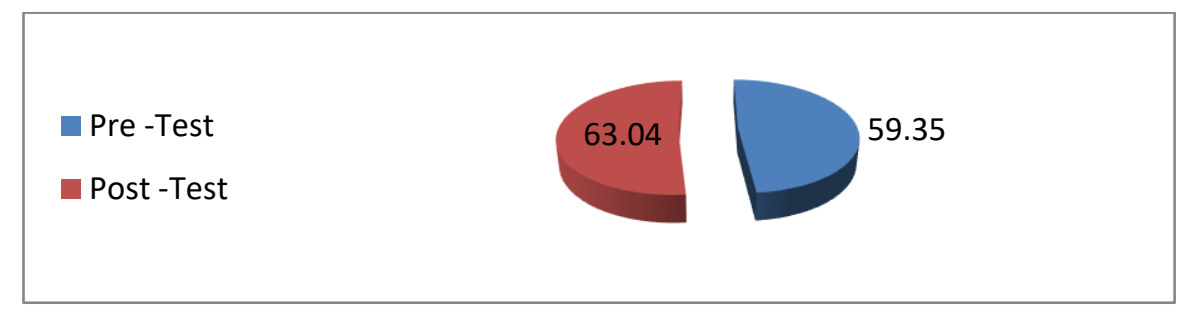

Figure 2:Control Group's Syntactic Complexity Results as a whole for Classification Essay.

\subsubsection{Syntactic Complexity of the control group in the Reaction Essay}


Table 3 presents the comparison results for the control group's syntactic complexity drawn from the reaction texts.

Table 3:The Comparison Results of the Control Group's Syntactic Complexity in the Reaction Texts.

\begin{tabular}{|c|c|c|c|c|c|}
\hline $\begin{array}{l}\text { Syntactic Complexity } \\
\text { Measures }\end{array}$ & Tests & $\mathrm{N}$ & Mean & $\begin{array}{l}\text { Standard } \\
\text { deviation }\end{array}$ & P-value \\
\hline \multirow[b]{2}{*}{ MLS=length of sentence } & Pre -Test & 28 & 15.73 & 4.35 & \multirow[t]{2}{*}{0.65} \\
\hline & Post -Test & 28 & 15.28 & 4.13 & \\
\hline \multirow[b]{2}{*}{ MLT=length of T unit } & Pre -Test & 28 & 13.73 & 3.31 & \multirow[t]{2}{*}{0.79} \\
\hline & Post -Test & 28 & 13.57 & 2.80 & \\
\hline \multirow[b]{2}{*}{ MLC=length of clause } & Pre -Test & 28 & 8.82 & 1.86 & \multirow[t]{2}{*}{0.65} \\
\hline & Post -Test & 28 & 8.97 & 1.33 & \\
\hline \multirow{2}{*}{$\begin{array}{l}\mathrm{C} / \mathrm{S}=\text { clauses per } \\
\text { sentence }\end{array}$} & Pre -Test & 28 & 1.81 & 0.49 & \multirow[t]{2}{*}{0.37} \\
\hline & Post -Test & 28 & 1.71 & 0.43 & \\
\hline \multirow{2}{*}{$\begin{array}{l}\mathrm{VP} / \mathrm{T}=\text { verb phrase per } \mathrm{T} \\
\text { unit }\end{array}$} & Pre -Test & 28 & 1.85 & 0.36 & \multirow[t]{2}{*}{0.48} \\
\hline & Post -Test & 28 & 1.82 & 0.37 & \\
\hline \multirow[b]{2}{*}{$\mathrm{C} / \mathrm{T}=$ clause per Tunit } & Pre -Test & 28 & 1.57 & 0.30 & \multirow[t]{2}{*}{0.28} \\
\hline & Post -Test & 28 & 1.52 & 0.25 & \\
\hline \multirow{2}{*}{$\begin{array}{l}\mathrm{DC} / \mathrm{C}=\text { dependent clause } \\
\text { per clause }\end{array}$} & Pre -Test & 28 & 0.31 & 0.11 & \multirow[t]{2}{*}{0.80} \\
\hline & Post -Test & 28 & 0.31 & 0.10 & \\
\hline \multirow{2}{*}{$\begin{array}{l}\mathrm{DC} / \mathrm{T}=\text { dependent clause } \\
\text { per T unit }\end{array}$} & Pre -Test & 28 & 0.51 & 0.26 & \multirow[t]{2}{*}{0.67} \\
\hline & Post -Test & 28 & 0.49 & 0.22 & \\
\hline \multirow{3}{*}{$\mathrm{T} / \mathrm{s}=$ Tunit per sentence } & Pre -Test & 28 & 1.15 & 0.16 & \multirow[t]{2}{*}{0.62} \\
\hline & Post-Test & 28 & 1.12 & 0.16 & \\
\hline & Pre -Test & 28 & 0.34 & 0.15 & 0.22 \\
\hline
\end{tabular}




\begin{tabular}{|c|c|c|c|c|c|}
\hline $\begin{array}{l}\mathrm{CT} / \mathrm{T}=\text { ComplexTunit } \\
\text { ratio }\end{array}$ & Post -Test & 28 & 0.37 & 0.15 & \\
\hline \multirow{2}{*}{$\begin{array}{l}\mathrm{CP} / \mathrm{T}=\text { coordinate phrase } \\
\text { per Tunit }\end{array}$} & Pre -Test & 28 & 0.48 & 0.27 & \multirow[t]{2}{*}{0.72} \\
\hline & Post -Test & 28 & 0.46 & 0.26 & \\
\hline \multirow{2}{*}{$\begin{array}{l}\mathrm{CP} / \mathrm{C}=\text { coordinate phrase } \\
\text { per clause }\end{array}$} & Pre -Test & 28 & 0.30 & 0.14 & \multirow[t]{2}{*}{1.00} \\
\hline & Post -Test & 28 & 0.30 & 0.16 & \\
\hline \multirow{2}{*}{$\begin{array}{l}\mathrm{CN} / \mathrm{T}=\text { complexnominals } \\
\text { per T unit }\end{array}$} & Pre -Test & 28 & 1.68 & 0.47 & \multirow[t]{2}{*}{0.98} \\
\hline & Post -Test & 28 & 1.68 & 0.49 & \\
\hline \multirow{2}{*}{$\begin{array}{l}\mathrm{CN} / \mathrm{C}=\text { complex } \\
\text { nominals per clause }\end{array}$} & Pre -Test & 28 & 1.08 & 0.24 & \multirow[t]{2}{*}{0.55} \\
\hline & Post -Test & 28 & 1.11 & 0.26 & \\
\hline \multirow{2}{*}{$\begin{array}{l}\text { Syntactic Complexity as } \\
\text { a whole }\end{array}$} & Pre -Test & 28 & 49.36 & 10.24 & \multirow{2}{*}{0.75} \\
\hline & Post -Test & 28 & 48.71 & 9.37 & \\
\hline
\end{tabular}

In terms of syntactic complexity, there were no statistically significant differences between each measure or between the total means of all measures of the pre- and post-tests. Therefore, no significant development or deterioration of syntactic complexity occurred for the Saudi EFL undergraduates during the reaction essay. Figure 3 presents the comparison results expressing syntactic complexity as a whole for reaction essay.

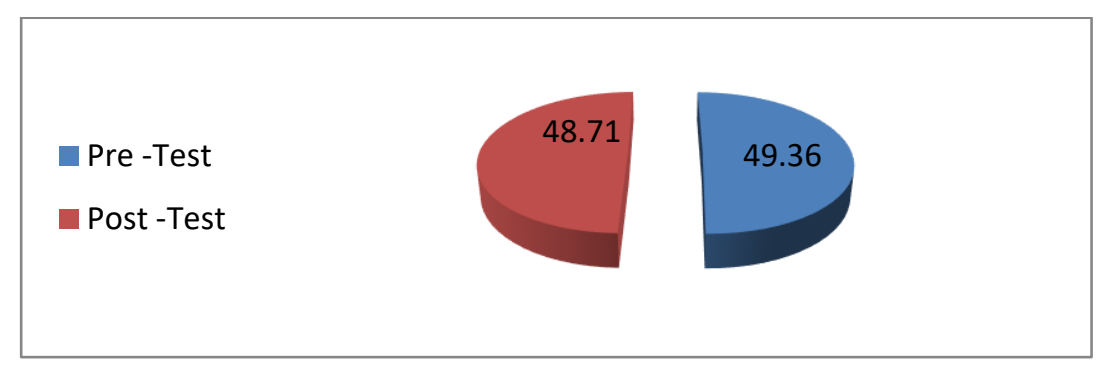

Figure 3:Control Group's Syntactic Complexity Results as a whole for the Reaction Essay. 


\subsection{Syntactic Complexity in the Experimental Group}

\subsubsection{The Results of Syntactic Complexity of the experimental group in the Argumentative Essay}

Table 4 presents the comparison results for the experimental group's syntactic complexity drawn from the argumentative texts.

Table 4:The Comparison Results of the Experimental Group's Syntactic Complexity in the Argumentative Texts.

\begin{tabular}{|c|c|c|c|c|c|}
\hline $\begin{array}{l}\text { Syntactic Complexity } \\
\text { Measures }\end{array}$ & Tests & $\mathrm{N}$ & Mean & $\begin{array}{l}\text { Standard } \\
\text { deviation }\end{array}$ & P-value \\
\hline \multirow[b]{2}{*}{ MLS=length of sentence } & Pre -Test & 20 & 15.80 & 3.25 & \multirow[t]{2}{*}{0.12} \\
\hline & Post -Test & 20 & 17.16 & 5.04 & \\
\hline \multirow[b]{2}{*}{ MLT=length of $\mathrm{T}$ unit } & Pre -Test & 20 & 14.75 & 2.84 & \multirow[t]{2}{*}{0.07} \\
\hline & Post -Test & 20 & 15.78 & 3.77 & \\
\hline \multirow[b]{2}{*}{ MLC=length of clause } & Pre -Test & 20 & 9.25 & 1.51 & \multirow[t]{2}{*}{0.16} \\
\hline & Post -Test & 20 & 9.71 & 1.85 & \\
\hline \multirow{2}{*}{$\begin{array}{l}\mathrm{C} / \mathrm{S}=\text { clauses per } \\
\text { sentence }\end{array}$} & Pre-Test & 20 & 1.71 & 0.22 & \multirow[t]{2}{*}{0.11} \\
\hline & Post -Test & 20 & 1.75 & 0.24 & \\
\hline \multirow{2}{*}{$\begin{array}{l}\text { VP/T=verb phrase per } \mathrm{T} \\
\text { unit }\end{array}$} & Pre -Test & 20 & 2.11 & 0.29 & \multirow[t]{2}{*}{0.84} \\
\hline & Post -Test & 20 & 2.10 & 0.30 & \\
\hline \multirow[b]{2}{*}{$\mathrm{C} / \mathrm{T}=$ clause per Tunit } & Pre -Test & 20 & 1.60 & 0.17 & \multirow[t]{2}{*}{0.30} \\
\hline & Post -Test & 20 & 1.62 & 0.17 & \\
\hline \multirow{2}{*}{$\begin{array}{l}\mathrm{DC} / \mathrm{C}=\text { dependent clause } \\
\text { per clause }\end{array}$} & Pre -Test & 20 & 0.36 & 0.07 & \multirow[t]{2}{*}{0.64} \\
\hline & Post -Test & 20 & 0.36 & 0.08 & \\
\hline \multirow{2}{*}{$\begin{array}{l}\mathrm{DC} / \mathrm{T}=\text { dependent clause } \\
\text { per T unit }\end{array}$} & Pre-Test & 20 & 0.58 & 0.15 & \multirow[t]{2}{*}{0.48} \\
\hline & Post -Test & 20 & 0.60 & 0.17 & \\
\hline
\end{tabular}




\begin{tabular}{|c|c|c|c|c|c|}
\hline \multirow[b]{2}{*}{$\mathrm{T} / \mathrm{s}=$ Tunit per sentence } & Pre -Test & 20 & 1.07 & 0.07 & \multirow[t]{2}{*}{0.45} \\
\hline & Post -Test & 20 & 1.08 & 0.09 & \\
\hline \multirow{2}{*}{$\begin{array}{l}\mathrm{CT} / \mathrm{T}=\text { ComplexTunit } \\
\text { ratio }\end{array}$} & Pre -Test & 20 & 0.44 & 0.12 & \multirow[t]{2}{*}{0.69} \\
\hline & Post -Test & 20 & 0.44 & 0.13 & \\
\hline \multirow{2}{*}{$\begin{array}{l}\mathrm{CP} / \mathrm{T}=\text { coordinate phrase } \\
\text { per Tunit }\end{array}$} & Pre -Test & 20 & 0.50 & 0.18 & \multirow[t]{2}{*}{0.05} \\
\hline & Post -Test & 20 & 0.56 & 0.25 & \\
\hline \multirow{2}{*}{$\begin{array}{l}\mathrm{CP} / \mathrm{C}=\text { coordinate phrase } \\
\text { per clause }\end{array}$} & Pre -Test & 20 & 0.31 & 0.10 & \multirow[t]{2}{*}{0.07} \\
\hline & Post -Test & 20 & 0.34 & 0.13 & \\
\hline \multirow{2}{*}{$\begin{array}{l}\mathrm{CN} / \mathrm{T}=\text { complexnominals } \\
\text { per T unit }\end{array}$} & Pre -Test & 20 & 1.84 & 0.52 & \multirow[t]{2}{*}{0.03} \\
\hline & Post -Test & 20 & 1.98 & 0.58 & \\
\hline \multirow{2}{*}{$\begin{array}{l}\mathrm{CN} / \mathrm{C}=\text { complex } \\
\text { nominals per clause }\end{array}$} & Pre -Test & 20 & 1.16 & 0.32 & \multirow[t]{2}{*}{0.13} \\
\hline & Post -Test & 20 & 1.22 & 0.30 & \\
\hline \multirow{2}{*}{$\begin{array}{l}\text { Syntactic Complexity as } \\
\text { a whole }\end{array}$} & Pre -Test & 20 & 51.47 & 8.70 & \multirow{2}{*}{0.09} \\
\hline & Post -Test & 20 & 54.70 & 11.96 & \\
\hline
\end{tabular}

Comparison results showed only one statistically significant difference: between the mean of $\mathrm{CN} / \mathrm{T}(\mathrm{M}=1.84)$ in the pre-test and the post-test mean $(\mathrm{M}=1.98)$ with a p-value of 0.03. By contrast, no statistically significant differences were found between the total means (pre-test: $\mathrm{M}=51.47$; post-test: $\mathrm{M}=54.70$; $\mathrm{p}$-value: 0.09 ), indicating no significant development or deterioration of syntactic complexity as a whole for Saudi EFL undergraduates. Nevertheless, the significant increase for one individual measure does indicate that the sub-construct was partially affected by the Telegram application during the argumentative essay. Figure 4 presents the comparison results expressing syntactic complexity as a whole for argumentative essay. 


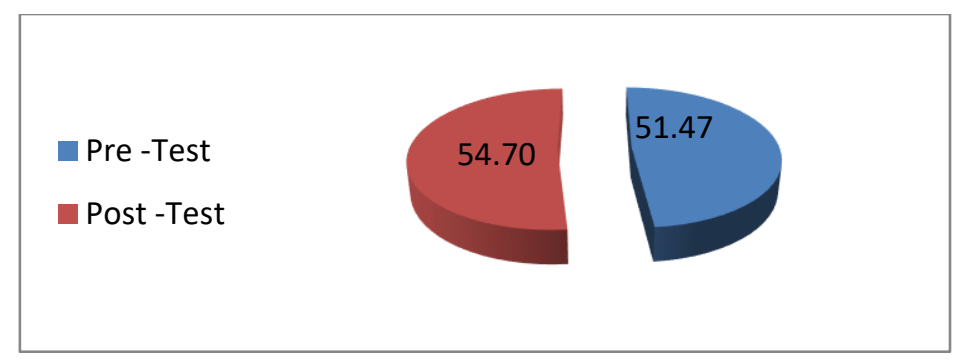

Figure 4:Experimental Group's Syntactic Complexity Results as a whole for Argumentative Essay.

\subsubsection{The Results of Syntactic Complexity of the experimental group in the Classification Essay}

Table 5 presents the comparison results for the experimental group's syntactic complexity drawn from the classification texts.

Table 5:The Comparison Results of the Experimental Group's Syntactic Complexity in the Classification Texts.

\begin{tabular}{|c|c|c|c|c|c|}
\hline $\begin{array}{l}\text { Syntactic Complexity } \\
\text { Measures }\end{array}$ & Tests & $\mathrm{N}$ & Mean & $\begin{array}{l}\text { Standard } \\
\text { deviation }\end{array}$ & P-value \\
\hline \multirow[b]{2}{*}{ MLS=length of sentence } & Pre -Test & 20 & 15.52 & 3.51 & \multirow[t]{2}{*}{0.01} \\
\hline & Post -Test & 20 & 17.60 & 2.72 & \\
\hline \multirow[b]{2}{*}{ MLT=length of T unit } & Pre -Test & 20 & 14.04 & 2.40 & \multirow[t]{2}{*}{0.01} \\
\hline & Post -Test & 20 & 16.19 & 2.53 & \\
\hline \multirow[b]{2}{*}{ MLC=length of clause } & Pre -Test & 20 & 9.73 & 1.83 & \multirow[t]{2}{*}{0.03} \\
\hline & Post -Test & 20 & 10.72 & 2.63 & \\
\hline \multirow{2}{*}{$\begin{array}{l}\mathrm{C} / \mathrm{S}=\text { clauses per } \\
\text { sentence }\end{array}$} & Pre -Test & 20 & 1.64 & 0.43 & \multirow[t]{2}{*}{0.42} \\
\hline & Post -Test & 20 & 1.70 & 0.35 & \\
\hline \multirow{2}{*}{$\begin{array}{l}\mathrm{VP} / \mathrm{T}=\text { verb phrase per } \mathrm{T} \\
\text { unit }\end{array}$} & Pre -Test & 20 & 2.27 & 0.35 & \multirow[t]{2}{*}{0.01} \\
\hline & Post -Test & 20 & 2.51 & 0.34 & \\
\hline $\mathrm{C} / \mathrm{T}=$ clause per Tunit & Pre -Test & 20 & 1.48 & 0.33 & 0.27 \\
\hline
\end{tabular}




\begin{tabular}{|c|c|c|c|c|c|}
\hline & Post -Test & 20 & 1.55 & 0.27 & \\
\hline \multirow{2}{*}{$\begin{array}{l}\mathrm{DC} / \mathrm{C}=\text { dependent clause } \\
\text { per clause }\end{array}$} & Pre -Test & 20 & 0.31 & 0.12 & \multirow[t]{2}{*}{0.26} \\
\hline & Post-Test & 20 & 0.34 & 0.10 & \\
\hline \multirow{2}{*}{$\begin{array}{l}\mathrm{DC} / \mathrm{T}=\text { dependent clause } \\
\text { per T unit }\end{array}$} & Pre -Test & 20 & 0.50 & 0.29 & \multirow[t]{2}{*}{0.38} \\
\hline & Post -Test & 20 & 0.54 & 0.23 & \\
\hline \multirow[b]{2}{*}{$\mathrm{T} / \mathrm{s}=$ Tunit per sentence } & Pre -Test & 20 & 1.10 & 0.14 & \multirow[t]{2}{*}{0.64} \\
\hline & Post -Test & 20 & 1.09 & 0.10 & \\
\hline \multirow{2}{*}{$\begin{array}{l}\mathrm{CT} / \mathrm{T}=\text { ComplexTunit } \\
\text { ratio }\end{array}$} & Pre -Test & 20 & 0.36 & 0.17 & \multirow[t]{2}{*}{0.11} \\
\hline & Post-Test & 20 & 0.41 & 0.14 & \\
\hline \multirow{2}{*}{$\begin{array}{l}\mathrm{CP} / \mathrm{T}=\text { coordinate phrase } \\
\text { per Tunit }\end{array}$} & Pre -Test & 20 & 0.45 & 0.26 & \multirow[t]{2}{*}{0.14} \\
\hline & Post -Test & 20 & 0.57 & 0.27 & \\
\hline \multirow{2}{*}{$\begin{array}{l}\mathrm{CP} / \mathrm{C}=\text { coordinate phrase } \\
\text { per clause }\end{array}$} & Pre -Test & 20 & 0.32 & 0.19 & \multirow[t]{2}{*}{0.20} \\
\hline & Post -Test & 20 & 0.38 & 0.22 & \\
\hline \multirow[b]{2}{*}{$\begin{array}{l}\mathrm{CN} / \mathrm{T}=\text { complex } \\
\text { nominals per } \mathrm{T} \text { unit }\end{array}$} & Pre -Test & 20 & 1.52 & 0.53 & \multirow[t]{2}{*}{0.01} \\
\hline & Post -Test & 20 & 1.91 & 0.47 & \\
\hline \multirow[b]{2}{*}{$\begin{array}{l}\mathrm{CN} / \mathrm{C}=\text { complex } \\
\text { nominals per clause }\end{array}$} & Pre -Test & 20 & 1.04 & 0.31 & \multirow[t]{2}{*}{0.01} \\
\hline & Post -Test & 20 & 1.27 & 0.43 & \\
\hline \multirow{2}{*}{$\begin{array}{l}\text { Syntactic Complexity as } \\
\text { a whole }\end{array}$} & Pre -Test & 20 & 50.28 & 7.52 & \multirow[t]{2}{*}{0.01} \\
\hline & Post -Test & 20 & 56.78 & 7.84 & \\
\hline
\end{tabular}

There were significant differences between the means of multiple syntactic complexity measures when comparing the test results for this essay: MLS $(M=15.52)$, $\operatorname{MLT}(M=14.04), \operatorname{MLC}(M=9.73), \mathrm{VP} / \mathrm{T}(\mathrm{M}=2.27), \mathrm{CN} / \mathrm{T}(\mathrm{M}=1.52)$, and $\mathrm{CN} / \mathrm{C}$ 
$(\mathrm{M}=1.04)$ for the pre-test with MLS $(\mathrm{M}=17.60)$, MLT $(\mathrm{M}=16.19)$, MLC $(\mathrm{M}=$ 10.72), VP/T $(\mathrm{M}=2.51), \mathrm{CN} / \mathrm{T}(\mathrm{M}=1.91)$, and $\mathrm{CN} / \mathrm{C}(\mathrm{M}=1.27)$ for the post-test. All p-values were 0.01 save that of MLC, which was 0.03 . The total means of all measures were significantly different as well (pre-test: $\mathrm{M}=50.28$; post-test: $\mathrm{M}=56.78$; $\mathrm{p}$-value: 0.01). These results reveal increased syntactic complexity for the experimental group as a whole and partially across specific measures. Figure 5 presents the comparison results expressing syntactic complexity as a whole for classification essay.

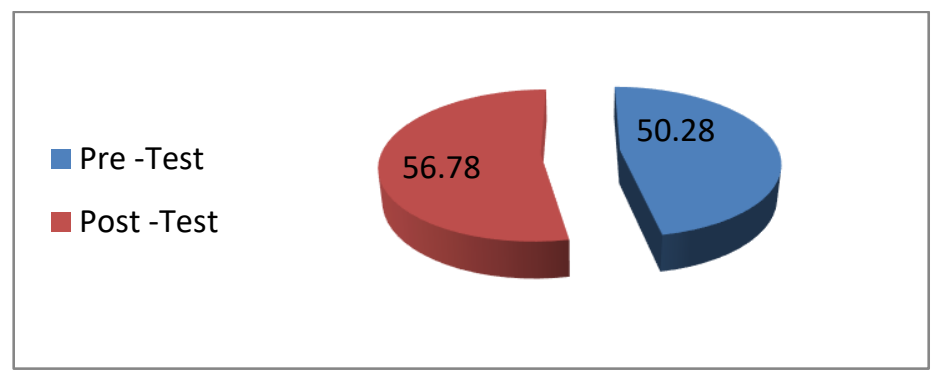

Figure 5:Experimental Group's Syntactic Complexity Results as a whole for Classification Essay.

\subsubsection{The Results of Syntactic Complexity of the Experimental Group in the Reaction Essay}

Table 6 presents the comparison results for the experimental group's syntactic complexity drawn from the reaction texts.

Table 6:The Comparison Results of the Experimental Group's Syntactic Complexity in the Reaction Texts.

\begin{tabular}{|l|l|l|l|l|l|}
\hline \multirow{2}{*}{\begin{tabular}{l} 
Measures \\
\multirow{2}{*}{ MLS=length of sentence }
\end{tabular}} & Tests & $\mathrm{N}$ & Mean & Standard & \multirow{2}{*}{ P-value } \\
\cline { 2 - 5 } & Pre -Test & 20 & 14.17 & 4.72 & 0.01 \\
\cline { 2 - 5 } & Post -Test & 20 & 14.77 & 5.05 & \\
\multirow{2}{*}{ MLT=length of T unit } & Pre -Test & 20 & 12.75 & 2.80 & \multirow{2}{*}{0.02} \\
\cline { 2 - 5 } & Post -Test & 20 & 13.39 & 2.95 & \\
\hline
\end{tabular}




\begin{tabular}{|c|c|c|c|c|c|}
\hline \multirow[b]{2}{*}{ MLC=length of clause } & Pre -Test & 20 & 8.79 & 1.43 & \multirow[t]{2}{*}{0.04} \\
\hline & Post -Test & 20 & 9.10 & 1.63 & \\
\hline \multirow{2}{*}{$\begin{array}{l}\mathrm{C} / \mathrm{S}=\text { clauses per } \\
\text { sentence }\end{array}$} & Pre -Test & 20 & 1.59 & 0.34 & \multirow[t]{2}{*}{0.66} \\
\hline & Post -Test & 20 & 1.60 & 0.35 & \\
\hline \multirow{2}{*}{$\begin{array}{l}\mathrm{VP} / \mathrm{T}=\text { verb phrase per } \mathrm{T} \\
\text { unit }\end{array}$} & Pre -Test & 20 & 1.85 & 0.42 & \multirow[t]{2}{*}{0.61} \\
\hline & Post -Test & 20 & 1.89 & 0.37 & \\
\hline \multirow[b]{2}{*}{$\mathrm{C} / \mathrm{T}=$ clause per Tunit } & Pre -Test & 20 & 1.45 & 0.22 & \multirow[t]{2}{*}{0.49} \\
\hline & Post -Test & 20 & 1.48 & 0.24 & \\
\hline \multirow{2}{*}{$\begin{array}{l}\mathrm{DC} / \mathrm{C}=\text { dependent clause } \\
\text { per clause }\end{array}$} & Pre -Test & 20 & 0.30 & 0.11 & \multirow[t]{2}{*}{0.37} \\
\hline & Post -Test & 20 & 0.31 & 0.11 & \\
\hline \multirow{2}{*}{$\begin{array}{l}\mathrm{DC} / \mathrm{T}=\text { dependent clause } \\
\text { per } \mathrm{T} \text { unit }\end{array}$} & Pre -Test & 20 & 0.45 & 0.23 & \multirow[t]{2}{*}{0.40} \\
\hline & Post -Test & 20 & 0.48 & 0.23 & \\
\hline \multirow[b]{2}{*}{$\mathrm{T} / \mathrm{s}=$ Tunit per sentence } & Pre -Test & 20 & 1.09 & 0.16 & \multirow[t]{2}{*}{0.42} \\
\hline & Post -Test & 20 & 1.08 & 0.16 & \\
\hline \multirow{2}{*}{$\begin{array}{l}\mathrm{CT} / \mathrm{T}=\text { ComplexTunit } \\
\text { ratio }\end{array}$} & Pre -Test & 20 & 0.34 & 0.14 & \multirow[t]{2}{*}{0.38} \\
\hline & Post -Test & 20 & 0.36 & 0.15 & \\
\hline \multirow{2}{*}{$\begin{array}{l}\mathrm{CP} / \mathrm{T}=\text { coordinate phrase } \\
\text { per Tunit }\end{array}$} & Pre -Test & 20 & 0.39 & 0.21 & \multirow[t]{2}{*}{0.11} \\
\hline & Post -Test & 20 & 0.45 & 0.21 & \\
\hline \multirow{2}{*}{$\begin{array}{l}\mathrm{CP} / \mathrm{C}=\text { coordinate phrase } \\
\text { per clause }\end{array}$} & Pre -Test & 20 & 0.27 & 0.14 & \multirow[t]{2}{*}{0.11} \\
\hline & Post -Test & 20 & 0.31 & 0.15 & \\
\hline \multirow{2}{*}{$\begin{array}{l}\mathrm{CN} / \mathrm{T}=\text { complexnominals } \\
\text { per T unit }\end{array}$} & Pre -Test & 20 & 1.40 & 0.44 & \multirow[t]{2}{*}{0.02} \\
\hline & Post -Test & 20 & 1.52 & 0.46 & \\
\hline \multirow{2}{*}{$\begin{array}{l}\mathrm{CN} / \mathrm{C}=\text { complex } \\
\text { nominals per clause }\end{array}$} & Pre -Test & 20 & 0.96 & 0.24 & \multirow[t]{2}{*}{0.07} \\
\hline & Post -Test & 20 & 1.03 & 0.28 & \\
\hline
\end{tabular}




\begin{tabular}{|l|l|l|l|l|l|}
\hline Syntactic Complexity as & Pre -Test & 20 & 45.81 & 10.25 & \multirow{2}{*}{0.01} \\
\cline { 2 - 5 } a whole & Post -Test & 20 & 47.78 & 10.89 & \\
\hline
\end{tabular}

Some statistically significant differences were found between the means of syntactic complexity measures, namely MLS $(\mathrm{M}=14.17), \operatorname{MLT}(\mathrm{M}=12.75), \operatorname{MLC}(\mathrm{M}$ = 8.79), and CN/T $(M=1.40)$ in the pre-test with $\operatorname{MLS}(\mathrm{M}=14.77), \operatorname{MLT}(\mathrm{M}=13.39)$, MLC $(M=9.10)$, and CN/T $(M=1.52)$ in the post-test. P-values for these measures were $0.01,0.02,0.04$, and 0.02 , respectively. Unsurprisingly, statistically significant difference was noted between the total means of all measures in the pre-test $(\mathrm{M}=45.81)$ and post-test $(\mathrm{M}=47.78)$ with a $\mathrm{p}$-value of 0.01 . These results indicate increased syntactic complexity for the experimental group as a whole and partially across specific measures when writing the reaction essay. Figure 6 presents the comparison results expressing syntactic complexity as a whole for reaction essay.

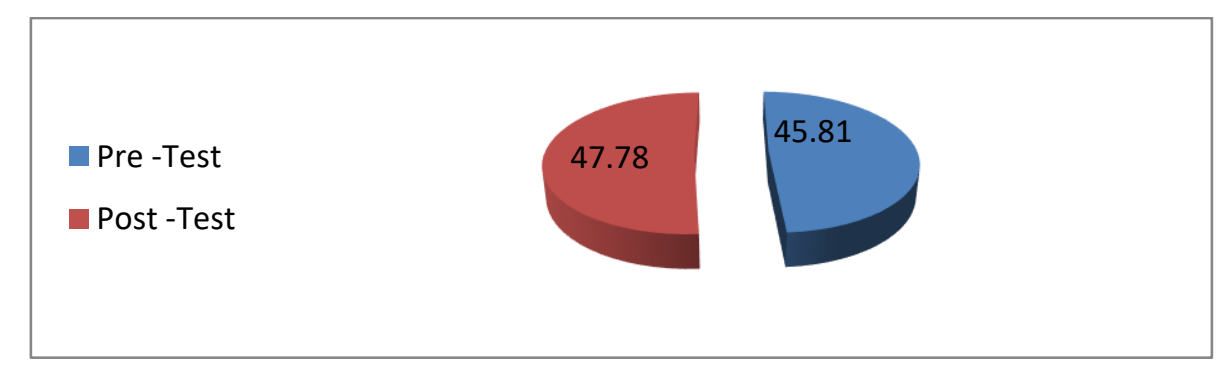

Figure 6:Experimental Group's Syntactic Complexity Results as a whole for Reaction Essay.

\subsection{Improvement of Syntactic Complexity in the Experimental and the}

\section{Control Groups}

\subsubsection{The Results of Syntactic Complexity of the control \&Experimental groups in the Argumentative Essay}

Table 7 presents the comparison results for the control \& experimental groups' syntactic complexity drawn from argumentative texts. 
Table 7:The Comparison Results of the Control and Experimental Groups' Syntactic Complexity in the Argumentative Texts.

\begin{tabular}{|c|c|c|c|c|c|}
\hline $\begin{array}{l}\text { Syntactic Complexity } \\
\text { Measures }\end{array}$ & Group & $\mathrm{N}$ & Mean & $\begin{array}{l}\text { Standard } \\
\text { deviation }\end{array}$ & P-value \\
\hline \multirow[b]{2}{*}{ MLS=length of sentence } & control & 28 & -0.32 & 3.22 & \multirow[t]{2}{*}{0.10} \\
\hline & experimental & 20 & 1.35 & 3.77 & \\
\hline \multirow[b]{2}{*}{ MLT=length of $\mathrm{T}$ unit } & control & 28 & 0.23 & 2.38 & \multirow[t]{2}{*}{0.26} \\
\hline & experimental & 20 & 1.02 & 2.35 & \\
\hline \multirow[b]{2}{*}{ MLC $=$ length of clause } & control & 28 & 0.06 & 1.01 & \multirow[t]{2}{*}{0.26} \\
\hline & experimental & 20 & 0.46 & 1.40 & \\
\hline \multirow{2}{*}{$\begin{array}{l}\mathrm{C} / \mathrm{S}=\text { clauses per } \\
\text { sentence }\end{array}$} & control & 28 & -0.05 & 0.40 & \multirow[t]{2}{*}{0.32} \\
\hline & experimental & 20 & 0.04 & 0.12 & \\
\hline \multirow{2}{*}{$\begin{array}{l}\mathrm{VP} / \mathrm{T}=\text { verb phrase per } \mathrm{T} \\
\text { unit }\end{array}$} & control & 28 & 0.04 & 0.39 & \multirow[t]{2}{*}{0.59} \\
\hline & experimental & 20 & -0.01 & 0.14 & \\
\hline \multirow[b]{2}{*}{$\mathrm{C} / \mathrm{T}=$ clause per Tunit } & control & 28 & 0.02 & 0.29 & \multirow[t]{2}{*}{0.96} \\
\hline & experimental & 20 & 0.02 & 0.10 & \\
\hline \multirow{2}{*}{$\begin{array}{l}\mathrm{DC} / \mathrm{C}=\text { dependent clause } \\
\text { per clause }\end{array}$} & control & 28 & 0.03 & 0.15 & \multirow[t]{2}{*}{0.52} \\
\hline & experimental & 20 & 0.01 & 0.06 & \\
\hline \multirow{2}{*}{$\begin{array}{l}\mathrm{DC} / \mathrm{T}=\text { dependent clause } \\
\text { per T unit }\end{array}$} & control & 28 & 0.06 & 0.33 & \multirow[t]{2}{*}{0.62} \\
\hline & experimental & 20 & 0.02 & 0.12 & \\
\hline \multirow[b]{2}{*}{$\mathrm{T} / \mathrm{s}=$ Tunit per sentence } & control & 28 & -0.01 & 0.18 & \multirow[t]{2}{*}{0.60} \\
\hline & experimental & 20 & 0.01 & 0.07 & \\
\hline \multirow{3}{*}{$\begin{array}{l}\mathrm{CT} / \mathrm{T}=\text { ComplexTunit } \\
\text { ratio }\end{array}$} & control & 28 & 0.00 & 0.15 & \multirow[t]{2}{*}{0.84} \\
\hline & experimental & 20 & 0.01 & 0.10 & \\
\hline & control & 28 & -0.02 & 0.26 & 0.24 \\
\hline
\end{tabular}




\begin{tabular}{|c|c|c|c|c|c|}
\hline $\begin{array}{l}\mathrm{CP} / \mathrm{T}=\text { coordinate phrase } \\
\text { per Tunit }\end{array}$ & experimental & 20 & 0.06 & 0.13 & \\
\hline \multirow{2}{*}{$\begin{array}{l}\mathrm{CP} / \mathrm{C}=\text { coordinate phrase } \\
\text { per clause }\end{array}$} & control & 28 & -0.01 & 0.16 & \multirow[t]{2}{*}{0.28} \\
\hline & experimental & 20 & 0.03 & 0.07 & \\
\hline \multirow{2}{*}{$\begin{array}{l}\mathrm{CN} / \mathrm{T}=\text { complexnominals } \\
\text { per } \mathrm{T} \text { unit }\end{array}$} & control & 28 & 0.11 & 0.44 & \multirow[t]{2}{*}{0.78} \\
\hline & experimental & 20 & 0.14 & 0.26 & \\
\hline \multirow{2}{*}{$\begin{array}{l}\mathrm{CN} / \mathrm{C}=\text { complex } \\
\text { nominals per clause }\end{array}$} & control & 28 & 0.04 & 0.21 & \multirow[t]{2}{*}{0.79} \\
\hline & experimental & 20 & 0.06 & 0.17 & \\
\hline \multirow{2}{*}{$\begin{array}{l}\text { Syntactic Complexity as } \\
\text { a whole }\end{array}$} & control & 28 & 0.19 & 7.46 & \multirow{2}{*}{0.18} \\
\hline & experimental & 20 & 3.23 & 8.02 & \\
\hline
\end{tabular}

The first comparison (between the means of each measure from both groups in the pre- and post-tests) found no statistically significant results. Similarly, the second comparison between the total means for all measures collectively, drawn from both groups at pre- and post-test intervals, produced no statistically significant findings. These results indicate that the syntactic complexity of Saudi EFL undergraduates did not change significantly, either partially or as a whole, during the argumentative essay. Figure 7 presents the comparison results expressing syntactic complexity as a whole for argumentative essay.

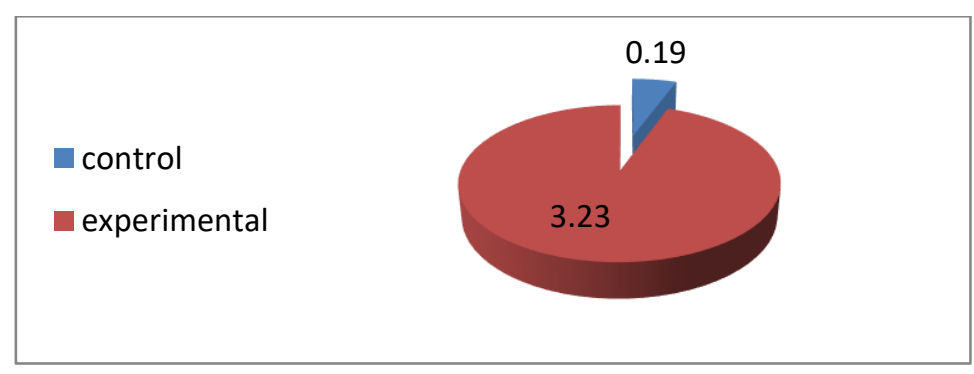

Figure 7:Control and Experimental Groups' Syntactic Complexity Results as a whole for Argumentative Essay. 


\subsubsection{The Results of Syntactic complexity of the control \&Experimental groups in the Classification Essay}

Table 8 presents the comparison results for the control \& experimental groups' syntactic complexity drawn from classification texts.

Table 8:The Comparison Results of the Control and Experimental Groups' Syntactic Complexity in the Classification Texts.

\begin{tabular}{|c|c|c|c|c|c|}
\hline $\begin{array}{l}\text { Syntactic Complexity } \\
\text { Measures }\end{array}$ & Group & $\mathrm{N}$ & Mean & $\begin{array}{l}\text { Standard } \\
\text { deviation }\end{array}$ & P-value \\
\hline \multirow[b]{2}{*}{ MLS=length of sentence } & control & 28 & 1.45 & 6.59 & \multirow[t]{2}{*}{0.69} \\
\hline & experimental & 20 & 2.08 & 2.49 & \\
\hline \multirow[b]{2}{*}{ MLT=length of $\mathrm{T}$ unit } & control & 28 & 1.41 & 6.88 & \multirow[t]{2}{*}{0.65} \\
\hline & experimental & 20 & 2.15 & 2.21 & \\
\hline \multirow[b]{2}{*}{ MLC $=$ length of clause } & control & 28 & 0.52 & 1.98 & \multirow[t]{2}{*}{0.41} \\
\hline & experimental & 20 & 0.99 & 1.88 & \\
\hline \multirow[t]{2}{*}{$\mathrm{C} / \mathrm{S}=$ clauses per } & control & 28 & 0.01 & 0.58 & \multirow[t]{2}{*}{0.76} \\
\hline & experimental & 20 & 0.06 & 0.31 & \\
\hline \multirow{2}{*}{$\begin{array}{l}\mathrm{VP} / \mathrm{T}=\text { verb phrase per } \mathrm{T} \\
\text { unit }\end{array}$} & control & 28 & -0.06 & 0.90 & \multirow[t]{2}{*}{0.17} \\
\hline & experimental & 20 & 0.24 & 0.34 & \\
\hline \multirow[b]{2}{*}{$\mathrm{C} / \mathrm{T}=$ clause per Tunit } & control & 28 & -0.04 & 0.53 & \multirow[t]{2}{*}{0.41} \\
\hline & experimental & 20 & 0.07 & 0.28 & \\
\hline \multirow{2}{*}{$\begin{array}{l}\mathrm{DC} / \mathrm{C}=\text { dependent clause } \\
\text { per clause }\end{array}$} & control & 28 & 0.01 & 0.13 & \multirow[t]{2}{*}{0.65} \\
\hline & experimental & 20 & 0.03 & 0.10 & \\
\hline \multirow{2}{*}{$\begin{array}{l}\mathrm{DC} / \mathrm{T}=\text { dependent clause } \\
\text { per } \mathrm{T} \text { unit }\end{array}$} & control & 28 & 0.02 & 0.48 & \multirow[t]{2}{*}{0.83} \\
\hline & experimental & 20 & 0.05 & 0.23 & \\
\hline
\end{tabular}




\begin{tabular}{|c|c|c|c|c|c|}
\hline & control & 28 & 0.00 & 0.13 & \multirow[t]{2}{*}{0.69} \\
\hline $\mathrm{T} / \mathrm{s}=$ Tunit per sentence & experimental & 20 & -0.01 & 0.11 & \\
\hline \multirow{2}{*}{$\begin{array}{l}\mathrm{CT} / \mathrm{T}=\text { ComplexTunit } \\
\text { ratio }\end{array}$} & control & 28 & 0.02 & 0.22 & \multirow[t]{2}{*}{0.51} \\
\hline & experimental & 20 & 0.06 & 0.16 & \\
\hline \multirow{2}{*}{$\begin{array}{l}\mathrm{CP} / \mathrm{T}=\text { coordinate phrase } \\
\text { per Tunit }\end{array}$} & control & 28 & 0.15 & 0.39 & \multirow[t]{2}{*}{0.76} \\
\hline & experimental & 20 & 0.11 & 0.33 & \\
\hline \multirow{2}{*}{$\begin{array}{l}\mathrm{CP} / \mathrm{C}=\text { coordinate phrase } \\
\text { per clause }\end{array}$} & control & 28 & 0.05 & 0.18 & \multirow[t]{2}{*}{0.82} \\
\hline & experimental & 20 & 0.06 & 0.21 & \\
\hline \multirow{2}{*}{$\begin{array}{l}\mathrm{CN} / \mathrm{T}=\text { complexnominals } \\
\text { per T unit }\end{array}$} & control & 28 & 0.11 & 1.00 & \multirow[t]{2}{*}{0.25} \\
\hline & experimental & 20 & 0.39 & 0.54 & \\
\hline \multirow{2}{*}{$\begin{array}{l}\mathrm{CN} / \mathrm{C}=\text { complex } \\
\text { nominals per clause }\end{array}$} & control & 28 & 0.04 & 0.34 & \multirow[t]{2}{*}{0.06} \\
\hline & experimental & 20 & 0.23 & 0.35 & \\
\hline \multirow{2}{*}{$\begin{array}{l}\text { Syntactic Complexity as } \\
\text { a whole }\end{array}$} & control & 28 & 3.69 & 17.13 & \multirow{2}{*}{0.49} \\
\hline & experimental & 20 & 6.50 & 6.61 & \\
\hline
\end{tabular}

None of the measures of syntactic complexity produced statistically significant differences between the pre- and post-test means of both groups, which was also true for the total means of all measures taken from both groups pre- and post-test. These results suggest no significant change in the syntactic complexity of Saudi EFL undergraduates, partially or as a whole, due to the classification essay. Figure 8 shows the comparison results expressing syntactic complexity as a whole for classification essay. 


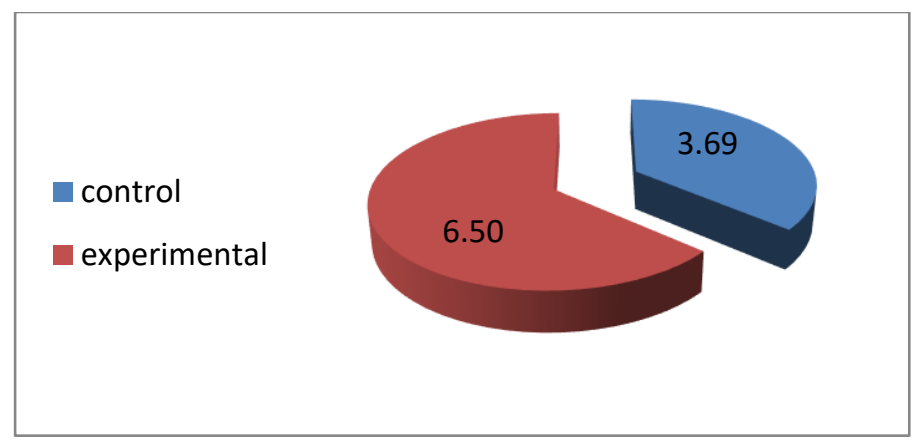

Figure 8: Control and Experimental Groups' Syntactic Complexity Results as a whole for Classification Essay.

\subsubsection{The Results of Syntactic Complexity of the Control \& Experimental groups in the Reaction Essay}

Table 9 presents the comparison results for the control \& experimental groups' syntactic complexity drawn from reaction texts.

Table 9:The Comparison Results of the Control and Experimental Groups' Syntactic Complexity in the Reaction Texts.

\begin{tabular}{|c|c|c|c|c|c|}
\hline $\begin{array}{l}\text { Syntactic Complexity } \\
\text { Measures }\end{array}$ & Group & $\mathrm{N}$ & Mean & $\begin{array}{l}\text { Standard } \\
\text { deviation }\end{array}$ & P-value \\
\hline \multirow[b]{2}{*}{ MLS=length of sentence } & control & 28 & -0.45 & 5.07 & \multirow[t]{2}{*}{0.37} \\
\hline & experimental & 20 & 0.60 & 0.89 & \\
\hline \multirow[b]{2}{*}{ MLT=length of $\mathrm{T}$ unit } & control & 28 & -0.16 & 3.12 & \multirow[t]{2}{*}{0.28} \\
\hline & experimental & 20 & 0.64 & 1.12 & \\
\hline \multirow[b]{2}{*}{ MLC $=$ length of clause } & control & 28 & 0.15 & 1.68 & \multirow[t]{2}{*}{0.68} \\
\hline & experimental & 20 & 0.31 & 0.63 & \\
\hline \multirow[t]{2}{*}{$\mathrm{C} / \mathrm{S}=$ clauses per } & control & 28 & -0.10 & 0.55 & \multirow[t]{2}{*}{0.39} \\
\hline & experimental & 20 & 0.01 & 0.14 & \\
\hline \multirow{2}{*}{$\begin{array}{l}\mathrm{VP} / \mathrm{T}=\text { verb phrase per } \mathrm{T} \\
\text { unit }\end{array}$} & control & 28 & -0.03 & 0.25 & \multirow[t]{2}{*}{0.39} \\
\hline & experimental & 20 & 0.04 & 0.31 & \\
\hline
\end{tabular}




\begin{tabular}{|c|c|c|c|c|c|}
\hline & control & 28 & -0.05 & 0.26 & \multirow[t]{2}{*}{0.23} \\
\hline $\mathrm{C} / \mathrm{T}=$ clause per Tunit & experimental & 20 & 0.03 & 0.17 & \\
\hline \multirow[t]{2}{*}{$\mathrm{DC} / \mathrm{C}=$ dependent clause } & control & 28 & 0.00 & 0.08 & \multirow[t]{2}{*}{0.70} \\
\hline & experimental & 20 & 0.01 & 0.06 & \\
\hline \multirow[t]{2}{*}{$\mathrm{DC} / \mathrm{T}=$ dependent clause } & control & 28 & -0.02 & 0.21 & \multirow[t]{2}{*}{0.42} \\
\hline & experimental & 20 & 0.03 & 0.14 & \\
\hline \multirow[b]{2}{*}{$\mathrm{T} / \mathrm{s}=$ Tunit per sentence } & control & 28 & -0.02 & 0.23 & \multirow[t]{2}{*}{0.82} \\
\hline & experimental & 20 & -0.01 & 0.05 & \\
\hline \multirow{2}{*}{$\begin{array}{l}\mathrm{CT} / \mathrm{T}=\text { ComplexTunit } \\
\text { ratio }\end{array}$} & control & 28 & 0.03 & 0.13 & \multirow[t]{2}{*}{0.77} \\
\hline & experimental & 20 & 0.02 & 0.10 & \\
\hline \multirow{2}{*}{$\begin{array}{l}\mathrm{CP} / \mathrm{T}=\text { coordinate phrase } \\
\text { per Tunit }\end{array}$} & control & 28 & -0.02 & 0.28 & \multirow[t]{2}{*}{0.27} \\
\hline & experimental & 20 & 0.06 & 0.16 & \\
\hline \multirow{2}{*}{$\begin{array}{l}\mathrm{CP} / \mathrm{C}=\text { coordinate phrase } \\
\text { per clause }\end{array}$} & control & 28 & 0.00 & 0.15 & \multirow[t]{2}{*}{0.30} \\
\hline & experimental & 20 & 0.04 & 0.11 & \\
\hline \multirow{2}{*}{$\begin{array}{l}\mathrm{CN} / \mathrm{T}=\text { complexnominals } \\
\text { per T unit }\end{array}$} & control & 28 & 0.00 & 0.51 & \multirow[t]{2}{*}{0.32} \\
\hline & experimental & 20 & 0.12 & 0.22 & \\
\hline \multirow{2}{*}{$\begin{array}{l}\mathrm{CN} / \mathrm{C}=\text { complex } \\
\text { nominals per clause }\end{array}$} & control & 28 & 0.03 & 0.26 & \multirow[t]{2}{*}{0.54} \\
\hline & experimental & 20 & 0.07 & 0.16 & \\
\hline \multirow[t]{2}{*}{ Syntactic Complexity as } & control & 28 & -0.64 & 10.56 & \multirow{2}{*}{0.29} \\
\hline & experimental & 20 & 1.97 & 2.80 & \\
\hline
\end{tabular}

There were no statistically significant differences between either group regarding any measure's means from the pre- and post-tests. Furthermore, the total means of all measures for both groups were not significantly different between tests, indicating unchanging syntactic complexity for the Saudi EFL undergraduates both as whole and 
across specific measures. Figure 9 shows the comparison results expressing syntactic complexity as a whole for reaction essay.

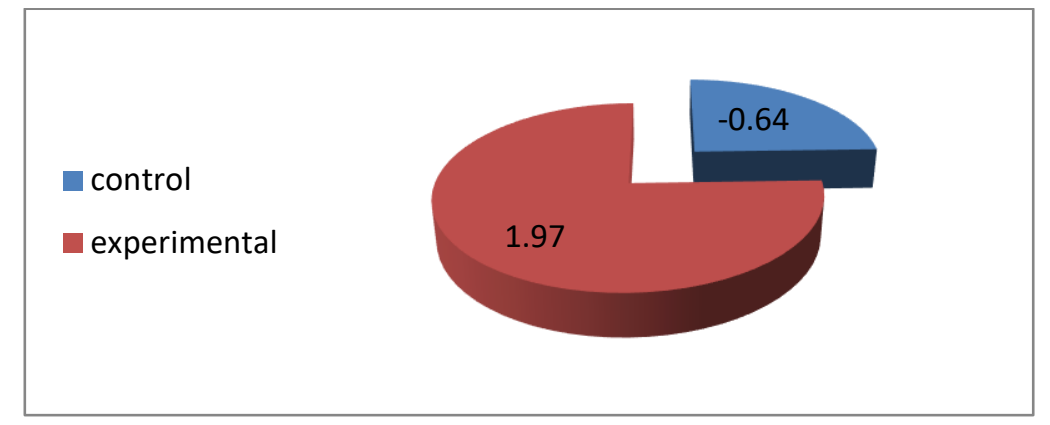

Figure 9:Control and Experimental Groups' Syntactic Complexity Results as a whole for Reaction Essay.

\subsection{Summary}

To sum up , this chapter has discussed the data analysis findings in relation to the fourteen points of syntactic complexity. The control group showed no increase or decrease in student syntactic complexity across any measure for any task, partially or as a whole. The experimental group showed no significant syntactic complexity improvement or deterioration during the argumentative essay as a whole, but did register improvement across one measure. The experimental group also enjoyed syntactic complexity improvement as a whole and partially across specific measures for the classification and reaction essays. When comparing the syntactic complexity of the control and experimental groups though, there was neither significant improvement nor deterioration across all measures for all tasks, either partially or as a whole. 


\section{Chapter Five}

\section{Discussion}

\subsection{Introduction}

This chapter discusses the results of the control and experimental groups as well the results of the comparison between the two groups in relation to the studies reviewed in the literature review.

\subsection{Research Question One: Did the control group's syntactic complexity} increase/decrease for the three writing tasks (argumentation, classification, and reaction) as a whole and/or across specific measures?

The results of this study showed that there was no increase/decrease in syntactic complexity, either as a whole or partially across individual measures, for the control group for the three writing tasks (argumentation, classification, and reaction). This would suggest that traditional learning methods does not reach to level to be significant on the syntactic skills of the participants in the control group. Such a finding would be in partial agreement with some studies in the literature. For example, Alghizzi (2017) found that, in the long term, the syntactic complexity of his study's traditional-learning environment group remained unchanged in the classification essay. Similarly, Hamad's 2015 study concluded that traditional learning methods provided no significant improvement overall in students' writing performance. These findings also correspond to those of Beers and Nagy (2011), whose work demonstrated that the process-genre approach in face-to-face teaching had no impact on the syntactic complexity of participants, neither as a whole nor partially across the two measures of clauses per Tunit and words per clause. 
The above-mentioned results of the current study could be attributed to two factors. The first factor is related to the process-genre approach. Even though Badger and White (2000), Shirinbakhsh and Saeidi (2018), and Arteaga-Lara (2017) have hypothesized that the process-genre approach would be likely to improve students' writing abilities, the available literature suggests that it does not, in fact, provide students with the language input needed to improve syntactic complexity. Rosmawati (2019), for example, concluded that a long exposure to traditional learning methods failed to provide students with language input adequate for developing their skills. The combination of traditional learning methods and the process-genre approach was found to be ineffective in developing syntactic complexity when tested by writing tasks of three different text types. This conclusion was partially supported by the work of Alghizzi and Alshahrani (2020), who found that students' syntactic complexity in the reaction essay was unaffected by the application of the process-genre approach in the traditional classroom.

The second factor influencing the results of this research is related to teachers. According to Alghizzi (2011, 2012), teachers play an important role in how EFL learners develop and correct their writing. He proposes that if writing instructors emphasize the importance of organization, clarity, grammar, spelling, capitalization, word choice, punctuation, and style - and use students' level of skill in these areas to evaluate them in exams—students will develop these aspects of their writing. Therefore, it could be suggested that the reason that control group participants in this study did not develop their syntactic complexity in the three writing tasks was due to a lack of emphasis on syntactic complexity by their teachers. 


\subsection{Research Question Two: Did the experimental group's syntactic}

complexity increase/decrease for the three writing tasks (argumentation, classification, and reaction) as a whole and/or across specific measures?

The results of the study showed that the syntactic complexity of the participants in the experimental group increased as a whole in both the classification and reaction essays. An increase in complexity was shown across the following measures for the classification essay: MLS, MLT, MLC, CN/T/VP/T, and CN/C. For the reaction essay, an increase in complexity was shown across MLS, MLT, MLC, and CN/T measures. Although the syntactic complexity of these participants did not increase/decrease as a whole for the argumentation essay, the CN/T measure did show some increase. Such findings are in partial agreement with a study in the literature. For example, Azodi and Lotfi (2020) found that the use of Telegram improved students' internal complexity (particularly their use of subordinate clauses), while their overall complexity remained unchanged.

There are two explanations for our findings in relation to the three writing tasks. The first explanation is found in the nature of these writing tasks and how students perceive them. Each of the three writing tasks employed in this research differs in its nature, goal, and manner of organization. According to Reza, Elaheh, and Laleh (2018), reaction, classification and expository essays are easier to master than argumentation and narrative essays. The studies of Pan (2018) and Jagaiah (2017) found that the syntactic complexity of their participants showed improvement for narrative and descriptive essays, but remained unchanged for argumentation essays. They both argue that argumentation essays pose the most challenges for learners, especially in aspects like organization and grammar. 
The second explanation is related to the length of the experiment in this study. The experiment was carried out over a period of ten weeks. The findings of the study suggest that this period was enough to increase students' performance somewhat in the reaction and classification tasks, but not in argumentation. Therefore, it can be inferred Telegram needs to be used for a longer period in order to have a positive effect on the argumentation task. Indeed, some studies have stressed the importance of time in blended-learning experiments. Ghaemi and Golshan (2017) argued that the application of social media is effective in the teaching of writing only when it is applied for a minimum of one full semester. While they did not specify the particular types of writing task that benefit from more time, they introduced time as a determining factor in the experiment. However, in a study published in 2019, Sarvari and Ezzati contradict the argument of Ghaemi and Golshan (2017). They maintain that Telegram improved students' writing performance in the short term for IELTS writing tasks. The researchers mention that prompts for the pre-test and the post-test in this study were drawn from IELTS, however they do not provide the full essay questions in their paper. It could be speculated, therefore, that the questions of the pre-test were more difficult than those of the post-test. The counter-intuitive results of the study could be explained if the researchers had given the students an argumentative task in the pre-test and other types of IELTS essays in the post-test.

After reviewing the students' results in the experimental group, a number of observations can be made. First, syntactic complexity as a whole improved in the classification and the reaction essays, while students' performance in $\mathrm{C} / \mathrm{S}, \mathrm{C} / \mathrm{T}, \mathrm{DC} / \mathrm{C}$, $\mathrm{DC} / \mathrm{T}, \mathrm{T} / \mathrm{S}, \mathrm{CT} / \mathrm{T}, \mathrm{CP} / \mathrm{T}, \mathrm{CP} / \mathrm{C}$ did not improve. Moreover, students' performance in the VP/T and CN/C remained unchanged in the reaction essay. Therefore, it could be inferred that these individual measures need more time than that given to improve. For 
the argumentation essay, syntactic complexity as a whole did not show significant improvement, except in the measure of CN/T. It could be concluded, therefore, that students are able to master the individual measure $\mathrm{CN} / \mathrm{T}$ more quickly than other measures. It was also observed that students tended to ask questions about the tasks that they found easy and avoided asking about the difficult tasks. Specifically, most of the questions on the Telegram group were about the reaction and classification essays, with very few relating to the argumentation essay.

\subsection{Research Question Three: Did the experimental group outperform the} control group in syntactic complexity when writing argumentation, classification, and reaction texts and, if so, to what extent?

Although the experimental group in this study showed more improvement in syntactic complexity than the control group, the degree of difference between the two groups was too small to draw any definite conclusion about the relative effectiveness of the two methods. This may be due to the comparatively short duration of the study — ten weeks. For more conclusive findings to be achieved, the study would need to be carried out over a longer period of time, as any difference between the two groups may require a long time to become visible. This is in line with Chuah (2014), whose study of the use of social media in the teaching of vocabulary indicated that time is a determining factor in the experiment. He concluded that to obtain good results, prolonged exposure to social media was required. Similarly, Ghaemi and Golshan (2017) have argued that social media must be applied for at least one full semester to have a positive impact on students' writing skills. 


\section{Chapter Six}

\section{Conclusion}

\subsection{Introduction}

This chapter offers a summary of the major findings of this study. It also discusses its implications and limitations, and provides recommendations and suggestions for future research.

\subsection{Summary of the results}

This study is an attempt to contribute to the literature on the teaching of writing in the context of Saudi EFL education. Its originality lies in the application of the increasingly popular social media app, Telegram, to the teaching of writing for college students.

The study was framed by three research questions. The first question sought to determine whether the syntactic complexity of students in the control group would increase or decrease significantly in a traditional learning environment, either as a whole or partially by specific measures. This was tested by setting the participants essay-writing tasks of three kinds: argumentation, classification, and reaction. The second question asked the same in relation to the experimental group. The third research question aimed to find out whether the experimental group outperformed the control group in syntactic complexity for the three types of essay.

To answer these questions, 48 Saudi EFL undergraduate students were chosen to participate in the experiment. The students were divided into two groups and placed into two different learning contexts. The first group consisted of 28 students and was taught according to traditional methods (the control group), while the second held 20 students who were taught with blended learning methods (the experimental group). The 
students of both groups were given the same pre- and post-test consisting of an argumentation, a classification, and a reaction essay, and they studied the same textbook. Their writings were gathered, processed, and analyzed. The analysis of their writings yielded the following results: In response to the first research question, the results showed that the syntactic complexity of the control group participants did not increase or decrease as a whole, or even partially across specific measures. This suggests that traditional teaching does not reach to level to be significant to the participants' syntactic complexity.

In response to the second research question, the results showed that the syntactic complexity of the experimental participants increased as a whole in both the classification and reaction essays. In addition, there was improvement in the classification essay across the following specific measures: MLS, MLT, MLC, $\mathrm{CN} / \mathrm{T} / \mathrm{VP} / \mathrm{T}$, and CN/C. An improvement was shown in the reaction essay across MLS, MLT, MLC, and CN/T. Although the syntactic complexity of these participants did not increase or decrease as a whole in the argumentation essay, it showed some improvement in relation to the $\mathrm{CN} / \mathrm{T}$ measure.

In relation to the third research question, the results showed that neither groups strongly outperformed the other. Such differences that there were in syntactic complexity were not statistically significant.

\subsection{Implications and recommendations}

The findings of this research have significant implications for academic research and for Saudi EFL teachers at the university level. First, this research enriches the literature on teaching and learning writing in relation to syntactic complexity in the Saudi context. It expands this literature by investigating the effect of four variables on the syntactic complexity of Saudi EFL undergraduate students - time (ten weeks), text 
type (argumentation, classification, and reaction), learning environment (traditional and blended), and proficiency (students at level six). These variables have hardly been addressed at all in previous research. The importance of this topic lies in the fact that, although EFL students in general, and Saudis in particular, view writing as the most difficult skill to learn and are, therefore, likely to hold negative attitudes towards it, they are also highly motivated to master it as it is important for their current studies and future careers. This motivation is encouraged by the many opportunities offered by the Saudi Ministry of Education to Saudi students at all levels (high school, undergraduate, graduate, and postgraduate) to pursue their studies in English-speaking countries. Many universities across the world require international students to meet a minimum score in the writing band of their language proficiency tests.

Second, this study is potentially helpful for EFL composition instructors, especially those who have no professional training in the teaching of writing or those who specialize in the teaching of other skills (reading, speaking, and listening) or other subjects (translation, linguistics, or literature). These instructors could use the findings of this study in relation to the aforementioned variables to devise their own way of teaching syntactic complexity. Furthermore, most EFL teachers receive no specific training in the process of teaching writing, and so lack expertise in this area and their knowledge of syntactic complexity can be limited. This study introduces them to 14 measures of syntactic complexity and to possible ways of improving them. The integration of technology into the teaching of writing and syntactic complexity has the potential to improve learners' performance in writing, and this study has explored this potential.

The above-mentioned implications can be of help in future research and educational reform. Based on the findings of the research, the researcher would like to 
make a number of recommendations related to both teacher training and blended learning. The first recommendation is related to teacher training: The teaching of writing skills should be included in EFL academic and professional training. One of the biggest flaws in the current system is that future EFL instructors are taught writing as a skill but not how to teach it. Such training would improve their teaching skills and would benefit learners.

The second recommendation is related to blended learning: This experiment has not shown conclusively that this type of learning has a significant impact on learners' writing skills. However, the results suggest that, given a study of longer duration, a positive impact is likely to be demonstrated. In light of this, EFL classes should move towards this method of teaching in the four language skills (reading, writing, listening, and speaking).

\subsection{Limitations and Suggestions for future research}

Although the current study yielded some results pertinent to the development of syntactic complexity in the Saudi EFL context, it was also limited by certain aspects of the following: research design used, participants, teaching method, type of writing tasks, measure of syntactic complexity tested, and duration of the experiment.

The first limitation was the research design adopted. The research made use of an exploratory-experimental quantitative research design. Data was collected from each participant's three essays. The data were then statistically analyzed. Additional useful data could be gathered if future studies on this topic would include a questionnaire to collect the opinions of participants on the traditional learning methods and the blended learning using Telegram. This would provide further support for any results. A mixedresearch approach of this kind would be helpful. 
The second limitation relates to the population of the study. In future studies, it is recommended to include more participants from both genders to obtain more representative results.

The third limitation is the teaching approach adopted. Future studies should expand the range of teaching methods used and include other forms of writing, such as narrative and descriptive, in order to test the hypothesis more thoroughly.

The fourth limitation of the study is that it focused only on syntactic complexity. The teaching of writing involves other aspects, such as fluency, accuracy, and lexical complexity (density, sophistication, and variation). This kind of study might yield different results if the experiment was applied to these aspects.

A further limitation of this research was the duration of the study. The experiment took place over ten weeks, and this relatively short duration might have affected its outcome. Future researchers should conduct the experiment over the course of a whole semester to gain more conclusive results. 


\section{References}

Abdul Haq, F. (1982). An Analysis of Syntactic Errors in the Composition of Jordanian Secondary Students (Unpublished master's thesis). Yarmouk University, Irbid, Jordan.

Afrin, S. (2016). Writing Problems of Non-English Major Undergraduate Students in Bangladesh: An Observation. Open Journal of Social Sciences, 104-115.

Aghajani, M., \& Adloo, M. (2018). The Effect of Online Cooperative Learning on Students' Writing Skills and Attitudes through Telegram application. International Journal of Instruction, 11(3), 433-448. doi: 10.12973/iji.2018.11330a

Ahmed, M. A. E. A. S. (2015). The Effect of Twitter on Developing Writing Skills in English as a Foreign Language. Arab World English Journal, Special issue on CALL (2), 134-149.

Akele, F. E. (2013). Information and Communication Technology as Teaching and Learning Space for Teachers of English Language in Schools. Journal of Emerging Trends in Educational Research and Policy Studies, 5(1), 100-107.

Al-Buainain H. (2009). Students' Writing Errors in EFL. International Journal of EFL, 7(12), 205-222. Retrieved from: http://ling.auf.net/lingbuzz/0010

Al Zumor, A. W. Q., Al Refaai, I. K., Eddin, E. A. B., \& Al-Rahman, F. H. A. (2013). EFL Students' Perceptions of a Blended Learning Environment: Advantages, Limitations and Suggestions for improvement. English Language Teaching, 6(10), 95-110. 
Al-Hammadi, F. (2011). The Effectiveness of Using a Multi-media Software in Developing Some Listening Skills among Saudi Secondary School Students. Damascus University Journal, 27(3/4), 43-86.

Al-Jarf, R. (2009, April). Enhancing Freshman Students' Writing Skills with a Mind Mapping Software. Paper presented at the ESL Conference of eLearning and Software for Education, Bucharest, Romania.

Al-Khairy, M. A. (2013). Saudi English-major Undergraduates’ Academic Writing Problems: A Taif University Perspective. English Language Teaching, 6(6), $1-12$.

Al-Seghayer, K. (2011). English Teaching in Saudi Arabia: Status, issues, and Challenges. Riyadh, Saudi Arabia: Hala.

Al-Seghayer, K. (2015). Salient Key Features of Actual English Instructional Practices in Saudi Arabia. English Language Teaching, 8(6), 89-99. doi:10.5539/elt.v8n6p89

Alghizzi, T. M. (2011). The Role of English Writing Instruction Methodologies on the Types of Written Mistakes/Errors EFL Graduate Diploma Students Can Identify in Their Writings (Unpublished graduate diploma thesis). Dublin International Foundation College, Dublin, Ireland.

Alghizzi, T. M. (2012). The Role of English Writing Instruction Methodologies on the Types of Written Mistakes/Errors Saudi EFL Pre-university Students Can Identify in Their Writings (Unpublished master's thesis). University College Cork, Cork, Ireland.

Alghizzi, T. M. (2017). Complexity, Accuracy, and Fluency (CAF) Development in L2 writing: The Effects of Proficiency Level, Learning Environment, Text 
Type, and Time among Saudi EFL learners. (Doctoral thesis, University

College Cork). Retrieved from https://cora.ucc.ie/handle/10468/4815

Alghizzi, T. M., \& Alshahrani, T. M. (2020). Determining the Effectiveness of the

Process Genre Approach in Increasing and Decreasing Saudi EFL University

Students' Complexity, Accuracy, and Fluency in Reaction Essays.

International Journal of English Linguistics, 10(1), 424-448.

Alkhezzi, F., \& Al-Dousari, W. (2016). The Impact of Mobile Learning on ESP

Learners' Performance. The Journal of Educators Online, 13(2), 73-101.

Allam, M., \& Elyas, T. (2016). Perceptions of Using Social Media as an ELT Tool among EFL Teachers in the Saudi Context. English Language Teaching, 9(7), $1-9$.

Allen, D., \& Katayama, A. (2016). Relative Second Language Proficiency and the Giving and Receiving of Written Peer feedback. System, 56, 96-106. doi: 10.1016/j.system.2015.12.002

Alsaleem, B. I. A. (2013). The Effect of "WhatsApp" Electronic Dialogue Journaling on Improving Writing Vocabulary Word Choice and Voice of EFL Undergraduate Saudi Students. Arab World English Journal, 4(3), 213-225.

Alsamdani, H. A. (2010). The Relationship between Saudi EFL Students' Writing Competence, L1 Writing Proficiency, and Self-regulation. European Journal of Social Sciences, 16(1),53-63.

Andújar-Vaca, A., \& Cruz-Martínez, M.-S. (2017). Mobile Instant Messaging:

WhatsApp and its Potential to Develop Oral Skills. Media Education Research Journal, 25(50), 43-52. doi: 10.3916/C50-2017-04

Arteaga-Lara, H. M. (2017). Using the Process-Genre Approach to improve FourthGrade EFL Llearners' Paragraph Writing. Latin American Journal of Content 
and Language Integrated Learning, 10(2), 217-244. doi:

10.5294/lacli1.2017.10.2.3

Azodi, N., \& Lotfi, A. (2020). E-collaborative Tasks and the Enhancement of Writing Performance among Iranian University-level EFL Learners. Turkish Online Journal of Distance Education, 21(1), 165-180.

Babalola, H. A. L. (2012). Effects of Process-Genre Based Approach on the Written English Performance of Computer Science Students in Nigerian Polytechnic. Journal of Education and Practice, 3(6), 1-5.

Badger, R., \& White, G. (2000). A Process Genre Approach to Teaching Writing. ELT Journal, 54(2), 153-160.

Badri, A. (2015). The Effects of Technology on Idioms: With a Focus on Law Terms (A Study in Payame Noor University, Tehran, Iran). International Journal of Educational Investigation, 2, 43-53.

Beers, S., \& Nagy, W. (2011). Writing Development in Four Genres from Grades Three to Seven: Syntactic Complexity and Genre Differentiation. Reading and Writing, 24, 183-202. 10.1007/s11145-010-9264-9.

Behzadi, A. (2015). Information and Communication Technology as the Teaching and Learning Space among Iranian EFL teachers. Indian Journal of Fundamental and Applied Life Sciences, 5(S3), 677-684.

Belachew, M., Getinet, M., \& Gashaye, A. (2015). Perception and Practice of SelfAssessment in EFL Writing Classrooms. Journal of Languages and Culture, $6(1), 1-8$

Browker, D. N. (2007). Academic Writing: A Guide to Tertiary Level Writing. Palmerston North, New Zealand: Massey University. 
Brown, H. D. (2000). Principles of Language Learning and Teaching. (4th ed.).White Plains, NY: Longman.

Brown, D. H. (2006). Principles of Language Learning and Teaching. Newark, NJ: Prentice-Hall.

Bulut, D., \& Abuseileek, A. (2007). Learner Attitude Toward CALL and Level of Achievement in Basic Language Skills. Sosyal Bilimler Enstitusu Dergisi Sayt, 2, 103-126.

Chang, C. C. (2014). Exploring the Determinants of e-Learning Systems Continuance Intention in Academic Libraries. Library Management, 34(1/2), 40-55. doi: $10.1108 / 01435121311298261$

Chuah, K.-M. (2014, August). Word's up With WhatsApp: The Use of Instant Messaging in Consciousness Raising of Academic Vocabulary. Paper presented at the 23rd MELTA and 12th Asia TEFL International Conference.

Deng, L., Chen, Q., \& Zhang, Y. (2014). Developing Chinese EFL learners' Generic Competence: A Genre-based and Process Genre Approach. New York, NY: Springer.

Dennen, V. P., Darabi, A. A., \& Smith, L. J. (2007). Instructor-learner Interaction in Online Courses: The Relative Perceived Importance of Particular Instructor Actions on Performance and Satisfaction. Distance Education, 28(1), 65-79.

Der Vyver, A. G. V \& Marais, M. A. (2015). Using Social Media as a Managerial Platform for an Educational Development Project: Cofimvaba. International Journal of Information and Education Technology, 5(12), 910-913. doi: 10.7763/IJIET.2015.V5.636

Ezza, E. S. (2010). Arab EFL Learners' Writing Dilemma at Tertiary Level. English Language Teaching, 3(4), 33. 
Fadda, H. A. (2012). Difficulties in Academic Writing: From the Perspective of King Saud University Postgraduate Students. English Language Teaching, 5(3), 123-130.

Fareh, S. (2010). Challenges of Teaching English in the Arab world: Why Can't EFL Programs Deliver as Expected? Procedia Social and Behavioral Sciences, 2, 3600-3604.

Fattah, S. F. E. S. A. (2015). The Effectiveness of Using WhatsApp Messenger as One of Mobile Learning Techniques to Develop Students' Writing Skills. Journal of Education and Practice, 6(32), 115-127.

Feez, S. (2001). Heritage and Innovation in Second Language Education. In A. M. Johns (Ed.), Genre in the classroom: Multiple perspectives (pp. 43-72). New York, NY: Routledge.

Fowler, W. S. (1989). Progressive Writing Skills. Walton-on-Thames, England: Nelson.

Friesen, N. (2012). Report: Defining Blended. Learning Spaces. Retrieved from: http://learningspaces.org/papers/Defining_Blended_Learning_NF.pdf

Frigaard, A. (2002). Does the Computer Lab Improve Student Performance on Vocabulary, Grammar, and Listening Comprehension? (Unpublished master's thesis). Winona State University, Winona, MN, United States.

Gao, J. (2007). Teaching Writing in Chinese University: Finding an Eclectic Approach. The Asian EFL Journal, 18, 1-2.

Garrison, D. R., \& Kanuka, H. (2004). Blended Learning: Uncovering its Transformative Potential in Higher Education. Internet and Higher Education, 7, 95-105. 
Ghada, A. (2016). Effect of WhatsApp on Critique Writing Proficiency and Perceptions toward Learning. Cogent Education, 1-26.

Ghaemi, F., \& Golshan, N. S. (2017). The Impact of Telegram as a Social Network on Teaching English Vocabulary among Iranian Intermediate EFL learners. International Journal of Media and Communication, 1(1), 23-29.

Ghavifekr, S., \& Rosdy, W. A. W. (2015). Teaching and Learning with Technology: Effectiveness of ICT Integration in Schools. International Journal of Research in Education and Science, 1(2), 175-191.

Ghufron, A. (2018). Process-genre Approach, Product Approach, and Students' SelfEsteem in Teaching Writing. Indonesian EFL Journal: Journal of ELT, Linguistics, and Literature, 2(1), 37-54.

Godfrey, L., Treacy, C., \& Tarone, E. (2014). Change in French Second Language Writing in Study Abroad and Domestic Contexts. Foreign Language Annals, $47(1), 48-65$.

Graham, C. R. (2006). Blended Learning Systems: Definition, Current Trends, and Future Directions. In Bonk, C. J., \& Graham, C. R., Handbook of blended learning: Global perspectives, local designs (pp. 3-18). San Francisco, CA: Pfeiffer.

Grami, G. M. A. (2010). The Effects of Integrating Peer Feedback into UniversityLevel ESL Writing Curriculum: A Comparative Study in a Saudi Context (Unpublished doctoral dissertation). Newcastle University, Newcastle, United Kingdom.

Hailu, S., \& Rustaman, N. (2012). Final Exam Report on First-semester Biology Teaching and Experience Gained from Indonesia. Bandung, Indonesia: Indonesia University of Education. 
Hamad, M. M. (2015). Blended Learning Outcome vs. Traditional Learning Outcome. International Journal on Studies in English Language and Literature, 3(4), $75-78$.

Hammond, J., and Derewianka, B. (2001). Genre. In R. Carter \& D. Nunan (Eds.), The Cambridge Guide to Teaching English to Speakers of Other Languages. Cambridge, UK: Cambridge University Press.

Harmer, J. (2001). English Language Teaching. San Francisco, CA: Longman

Hasan, M. K., \& Akhand, M. M. (2010). Approaches to Writing in EFL/ESL Context: Balancing Product and Process in Writing Class at Tertiary Level. Journal of NELTA, 15(1), 77-88.

Hashim, N. (1996). English Syntactic Errors by Arabic Speaking Learners: Reviewed. Jeddah, Saudi Arabia: King Abdulaziz University.

Haswani, F. (2014). The Role of Technology in EFL Classroom. Indonesian Journal of English Education, 1(2), doi: 10.15408/ijee.v1i2.1303.

Hatim, B. (1990). A Model of Argumentation from ArabicRhetoric: Insights for a Theory of Text Types. British Journal of Middle Eastern Studies, 17(1), 4754.

He, L., Shi, L. (2008). ESL Students' Perceptions and Experiences of Standardized English Writing Tests. Assessing Writing, 13(2008), 130-149.

Heidar, D. M., \& Kaviani, M. (2016). The Social Impact of Telegram as a Social Network on Teaching English Vocabulary among Iranian Intermediate EFL Learners (Payam Noor Center). Sociological Studies of Youth, 7(23), 65-76.

Hidayati, H. K. (2018). Teaching Writing to EFL Learners: An Investigation of Challenges Confronted by Indonesian Teachers. Langkawi, 4(21), doi: 10.31332/lkw.v4i1.772. 
Horn, M., \& Staker, H. (2015). Blended: Using Disruptive Innovation to Improve Schools. San Francisco, CA: Jossey-Bass.

Hyland, K. (2003). Second Language Writing. Cambridge, UK: Cambridge University Press.

Hyland, K. (2004). Genre and Second Language Writing. Ann Arbor, MI: University of Michigan Press.

Hyland, K. (2007). Genre Pedagogy: Language, Lliteracy and L2 Writing Instruction . Journal of Second Language Writing, 16(3), 148-164.

Iksan, Z. H., \& Saufian, S. M. (2017). Mobile Learning: Innovation in Teaching and Learning Using Telegram. International Journal of Pedagogy and Teacher Education, 1(1), 19-26.

Jackson, R. J. (2006). Genre Process Writing and Testing. Journal of Education and Practice, 2(3), 12-18.

Jagaiah, T. (2017). Analysis of Syntactic Complexity and its Relationship to Writing Quality in Argumentative Essays (Unpublished doctoral dissertation). University of Connecticut, Mansfield, CT, United States.

Jang, E. (2009). Cognitive Diagnostic Assessment of L2 Reading Comprehension` ability: Validity Arguments for Fusion Model Application to Language Assessment. Language Testing, 26(1), 31-73.

Javid, C. Z., Farooq, M. U., \& Umer, M. (2013). An Investigation of Saudi EFL Learners' Writing Problems: A Case Study along Gender Lines. Kashmir Journal of Language Research, 16(1), 179-203.

Javid, C. Z., \& Umer, M. (2014). Saudi EFL Learners' Writing Problems: A Move towards Solution. Proceedings of the Global Summit on Education GSE, 2014, $4-5$. 
Justina, M. (2016). Use of WhatsApp to Enhance Reading and Writing Skills at Undergraduate College Level. Language in India, 16(11), 47-60.

Kasanen, K., \& Räty, H. (2002). "You be Sure Now to Be Honest in Your Assessment": Teaching and Learning Self-assessment. Social Psychology of Education, 5(4), 313-328.

Kellog, R. T. (2008). Improving the Writing Skills of College Students. Journal of Writing Research, 1(1), 1-26.

Knoch, U., Rouhshad, A., \& Storch, N. (2014). Does the Writing of Undergraduate ESL Students Develop after One Year of Study in an English-medium University? Assessing Writing, 21, 1-17.

Knoch, U., Rouhshad, A., Oon, S. P., \& Storch, N. (2015). What Happens to ESL Students' Writing after Three Years of Study at an English Medium university? Journal of Second Language Writing, 28, 39-52.

Larkin, T. L., \& Belson, S., I. (2005). Blackboard Technologies: A Vehicle to Promote Students' Motivation in Physics. Journal of STEM Education, 6(1), $14-27$.

Larsen-Freeman, D. (2006). The Emergence of Complexity, Fluency, and Accuracy in the Oral and Written Production of Five Chinese Learners of English. Applied Linguistics, 27, 590-619.

Larsen-Freeman, D. (2012). Complex, Dynamic Systems: A New Transdisciplinary Theme for Applied Linguistics? Language Teaching, 45, 202-214. doi:

$10.1017 / \mathrm{S} 0261444811000061$

Lee, I. (2011). Formative Assessment in EFL Writing: An Exploratory Case Study. Changing English, 18(1), 99-111. 
Lee, S. (2015). L2 Writing Instruction in Blended Learning for the Development of Fluency, Complexity, and Accuracy in Higher Education. MultimediaAssisted Language Learning, 18(4), 121-147. doi:

10.15702/mall.2015.18.4.121

Leki, I., Cumming, A., \& Silva, T. (2008). A Synthesis of Research on Second Language Writing. New York, NY: Routledge.

Li, X. (2008). Cognitive Transfer and English Writing. English Language Teaching, l(1), 113-115. doi: 10.5539/elt.v1n1p113

Liaw, S. (2008). Investigating Students' Perceived Satisfaction, Behavioral Intention, and Effectiveness of e-learning: A Case Study of the Blackboard System. Computers and Education, 51(2), 864-873. doi: 10.1016/j.compedu.2007.09.005

Liss, R., \& Davis, J. (2006). Effective Academic Writing. New York, NY: Oxford University Press.

Lorenzo, F., \& Rodríguez, L. (2014). Onset and Expansion of L2 Cognitive Academic Language Proficiency in Bilingual Settings: CALP in CLIL. System, 47, 6472.

Ministry of Education. (2004). The Development of Education: National Report of the Kingdom of Saudi Arabia (2000-2004). Riyadh: Dar Al-Hilal Press.

Mishra, P., \& Koehler, M. J. (2006). Technological Pedagogical Content Knowledge: A Framework for Integrating Technology in Teacher Knowledge. Teachers College Record, 108(6), 1017-1054.

Motaghian, H., Hassanzadeh, A., \& Moghadam, D. K. (2013). Factors Affecting University Instructors’ Adoption of Web-based Learning Systems: Case Study of Iran. Computers \& Education, 61, 158-167. 
Mouakket, S., \& Anissa, B. (2015). Investigating the Factors Influencing Continuance Usage Intention of Learning Management Systems by University Instructors: The Blackboard case. International Journal of Web Information Systems, 11(4), 491-509. doi: 10.1108/IJWIS-03-2015-0008

Muncie, J. (2002). Process Writing and Vocabulary Development: Comparing Lexical Frequency Profiles across Drafts. System, 30(2), 225-235. doi: $10.1016 / \mathrm{S} 0346-251 \mathrm{X}(02) 00006-4$

Myles, J. (2002). Second-language Writing and Research: The Writing Process and Error Analysis in Student Texts. Teaching English as a Second or Foreign Language, 6(2), 1-18.

Nabati, A. (2018) Teaching Grammar through Social Networks and its Effect on Students' Writing Accuracy (Unpublished master's thesis). Islamic Azad University, Qom, Iran.

Navés, T., Torras, M. R., \& Celaya, M. L. (2003). Long-term Effects of an Earlier Start: An analysis of EFL Written Production. In S. Foster-Cohen \& S. Pekarek Doehler (Eds.), EUROSLA yearbook: Annual Conference of the European Second Language Association (pp. 103-130). Amsterdam, the Netherlands: John Benjamins.

Nedal, A., \& Hani, B. (2014). The Impact of WhatsApp Group's Utilization of EFL Students' Vocabulary Writing Amelioration. International Journal of University Teaching and Faculty Development, 5(2), 73-87.

Nunan, D. (1999). Second language Teaching and Learning. Boston, MA: Heinle \& Heinle.

Otroshi M. H., \& Bourdet J. F. (2012, November). ICT and the Problem of Integration in the Teaching/learning of French as a Foreign Language in Iran. Paper 
presented at the Fifth Annual International Conference on ICT for Language Learning, Florence, Italy.

Pan, X. (2018). Investigating the Development of Syntactic Complexity in L2 Chinese Writing (Unpublished doctoral dissertation). University of Iowa, Iowa City, IA, United States.

Panadero, E., Brown, G., \& Courtney, M. (2014). Teachers' Reasons for Using SelfAssessment: A Survey Self-report of Spanish Teachers. Assessment in Education: Principles, Policy and Practice, 21(4), 365-383.

Pasand, P. G., \& Haghi, E. B. (2013). Process-product Approach to Writing: The Effect of Model Essays on EFL Leaners' Writing Accuracy. International Journal of Applied Linguistics \& English Literature, 2(1), 75-79.

Perin, D. (2013). Best Practices in Teaching Writing for College and Career Readiness. In Graham, S., MacArthur, C. A., \& Fitzgerald, J. (Eds.), Best Practices in Writing Instruction (pp. 48-70). New York, NY: Guilford Press. Poon, J. (2013). Blended learning: An Institutional Approach for Enhancing Students' Learning Experiences. Journal of Online Learning and Teaching, 9(2), 271288. Retrieved from http://jolt.merlot.org/vol9no2/poon_0613.htm

Qarajeh, M., \& Abdolmanafi, J. (2015). The Impact of Social Networking on the Oral Performance of EFL Learners. Advances in Language and Literary Studies, 6(2), 51-56.

Rababah, G. (2003). Communication Problems Facing Arab learners of English: A Personal Perspective. TEFL Web Journal, 2(1), 15-30.

Rahma, N., Bandjarjani, W., \& Andanty, F. D. (2018). The Influence of Using Telegram on the Writing Achievement of XI Grade Students at SMKN 8 
Surabaya. Prosodi, 12(2), 206-210 . Retrieved from:

https://journal.trunojoyo.ac.id/prosodi/article/view/4223/3147

Reza K., Elaheh M., \& Laleh K. (2018). The Effect of Task-based Language

Teaching on Analytic Writing in EFL Classrooms. Cogent Education, 5(1), 1496627, doi: 10.1080/2331186X.2018.1496627

Richards, J. C., \& Renandya, W. A. (Eds.). (2002). Methodology in Language Teaching: An Anthology of Current Practice. Cambridge, UK: Cambridge University Press.

Rosmawati, M. (2014). Dynamic Development of Complexity and Accuracy: A case Study in Second Language Academic Writing. Australian Review of Applied Linguistics, 37(2), 75-100.

Rosmawati, M. (2019). Syntactic Complexity in Second Language Academic Writing in English: Diversity on Display. In: Wright, C., Harvey, L., \& Simpson, J. (Eds.), Voices and practices in applied linguistics: Diversifying a discipline (pp. 251-270). York, UK: White Rose University Press. doi:

\subsection{9/BAAL1.o}

Saeidi, M., \& Sahebkheir, F. (2011). The Effect of Model Essays on Accuracy and Complexity of EFL Learners' Writing Performance. Middle-East Journal of Scientific Research, 10(1), 130-137.

Sarvari, S., \& Ezzati, E. (2019). Teaching Writing through Telegram Social Network and its Effect on EFL learners' Writing Performance. International Journal of Foreign Language Teaching and Research, 7(25), 87-100.

Saunders, M., Lewis, P., \& Thornhill, A. (2012). Research Methods for Business Students. 6th ed. New York, NY: Pearson Education. 
Servonsky, W. L., Daniels, W. L., \& Davis, B. L. (2005). Evaluation of Blackboard as a Platform for Distance Education Delivery. The ABNF Journal, 16(6), 132135.

Shirinbakhsh, S., \& Saeidi, F. (2018). The Effectiveness of Telegram for Improving Students' Reading Ability. Journal of Applied Linguistics and Language Research, 4(5), 118-129.

Singh, K. (2007). Quantitative Social Research Methods. New Delhi: SAGE Publications India Pvt Ltd doi:10.4135/9789351507741

Steele, V. (1992). Product and Process Writing: A Comparison. Rowley, MA: Newbury House.

Storch, N. (2009). The Impact of Studying in a Second Language (L2) MediumUniversity on the Development of L2 Writing. Journal of Second Language Writing, 18(2), 103-118.

Sun, P. C., Tsai, R. J., Finger, G., Chen, Y.-Y., \& Yeh, D. (2008). What Drives a Successful el-earning? An Empirical Investigation of the Critical Factors Influencing Learner Satisfaction. Computers \& Education, 50(4), 1183-1202. doi: 10.1016/j.compedu.2006.11.007

Tang, R. (2012). Academic Writing in a Second or Foreign Language: Issues and Challenges Facing ESL/EFL Academic Writers in Higher Education Contexts. London, UK: Bloomsbury Publishing.

Tangpermpoon, T. (2008). Integrated Approaches to Improve Students Writing Skills for English Major students. ABAC Journal, 28(2), 1-9.

Tella, A. (2012). System-related Factors that Predict Students' Satisfaction with the Blackboard Learning System at the University of Botswana. African Journal of Library, Archives and Information Science, 22(1), 41-52. 
Thewissen, J. (2013). Capturing L2 Accuracy Developmental Patterns: Insights from an Error-tagged Learner Corpus. The Modern Language Journal, 97, 77-101.

Thuy, N. H. (2009). Teaching EFL writing in Vietnam: Problems and Solutions-A Discussion from the Outlook of Applied Linguistics. Journal of Science, Foreign Languages, 24(2009), 61-66.

Timucin, M. (2006). Implementing CALL in the EFL Context. ELT Journal, 60(3), $262-271$.

Tribble, C. (1996). Writing. Oxford: Oxford University Press.

Tuan, L. T. (2011). Teaching Writing through Genre-based Approach. Theory and Practice in Language Studies, 1(11), 1471-1478.

Tze, Y. S., Dewika, N., \& Devandran, A. (2014). Improving Students' Engagement through Social Media: A Case Study of a Private University in Malaysia using FaceBook. International Journal of e-Education, e-Business, e-Management and e-Learning, 4(6), 396-409.

Wall, J., \& Ahmed, V. (2008). Lessons Learned from a Case Study in Deploying Blended Learning Continuing Professional Development. Engineering, Construction and Architectural Management, 15(2), 185-202.

Wang, W. (2014). Students' Perceptions of Rubric-referenced Peer Feedback on EFL Writing: A Longitudinal Inquiry. Assessing Writing, 19(2014) 80-96.

Wind, A. M. (2013). Second Language Writing Development from a Dynamic Systems Theory Perspective. In B.-P. Olmos-López, J. Huang, \& J. Almeida (Eds.), Papers from the 8th Lancaster University postgraduate conference in Linguistics \& Language Teaching 2012 (pp. 90-123). Lancaster, UK: Lancaster University. 
Xodabande, I. (2017). The Effectiveness of Social Media Network Telegram in Teaching English Language Pronunciation to Iranian EFL learners. Cogent Education, 4(1), 1-14. doi: 10.1080/2331186X.2017.1347081

Yan, G. (2005). A Process Genre Model for Teaching Writing. English Teaching Forum, 43(3), 18-26.

Yang, W., Lu, X., \& Weigle, S. C. (2015). Different Topics, Different Discourse: Relationships among Writing Topic, Measures of Syntactic Complexity, and Judgments of Writing Quality. Journal of Second Language Writing, 28, 5367. doi: 10.1016/j.jslw.2015.02.002

Yinka, A. R. \& Queendarline, N. N. (2018). Telegram as a Social Media Tool for Teaching and Learning in Tertiary Institutions. International Journal of Multidisciplinary Research and Development, 5(7), 95-98.

Yitong, W., Yinghui, S., Hao Y. H., \& Jianqing, L. (2017). Blended Learning Versus `Traditional Learning: A Study on Students’ Learning Achievements and Academic press. Conference Proceedings: 2017 International Symposium on Educational Technology, volume 1 (pp. 219-223). doi: 10.1109/ISET.2017.57 


\section{Appendices}

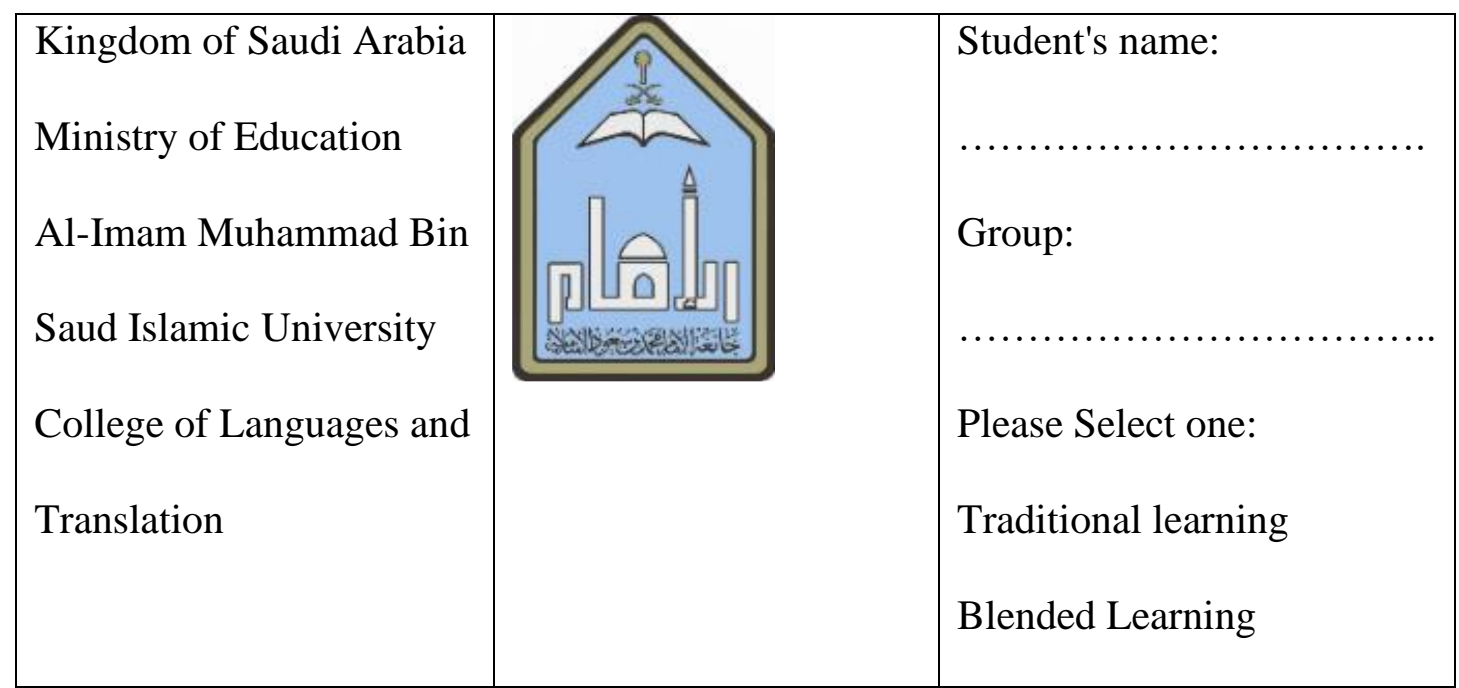

Appendix (A)

Pretest

Write a 250-word essay (six paragraphs) on each of the following prompts:

1) Some people think that parents should teach children how to be good members of society. Others, however, believe that school is the place to learn this. Discuss both these views and give your own opinion.

2) How would you categorize options for your vacation planning?

3) Write a reaction essay in response to these two photographs.

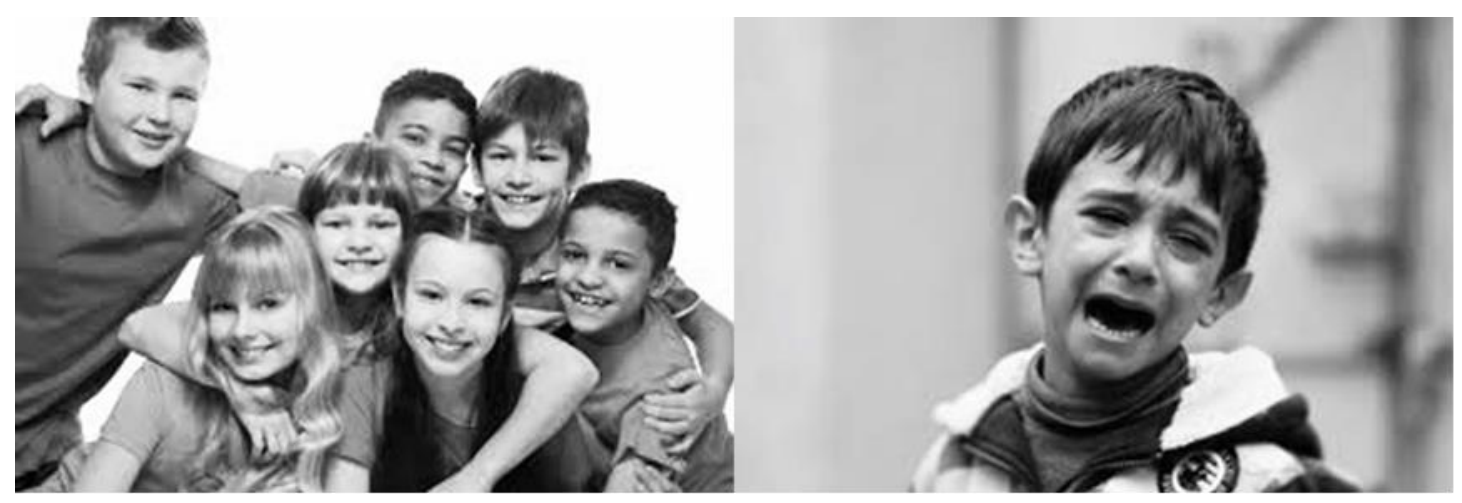




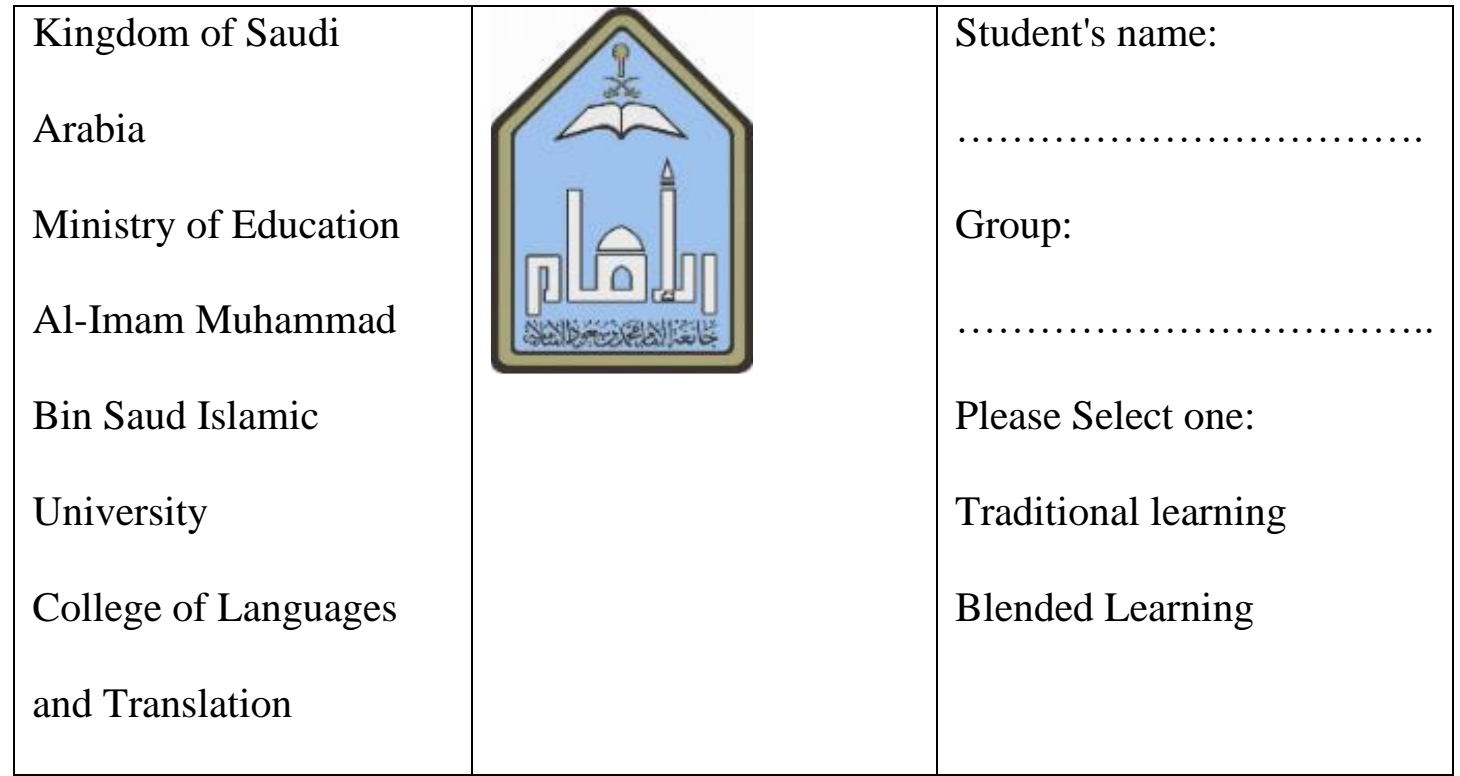

Appendix (B)

Posttest

Write a 250-word essay (six paragraphs) on each of the following prompts:

1) Some people think that it is better to educate boys and girls in separate

schools. Others, however, believe that boys and girls benefit more from attending mixed schools.Discuss both these views and give your own opinion.

2) In some countries young people are encouraged to work or travel for a year between finishing high school and starting university studies.Discuss the advantages and disadvantages for young people who decide to do this.

3) Write a reaction essay in response to these two photographs.

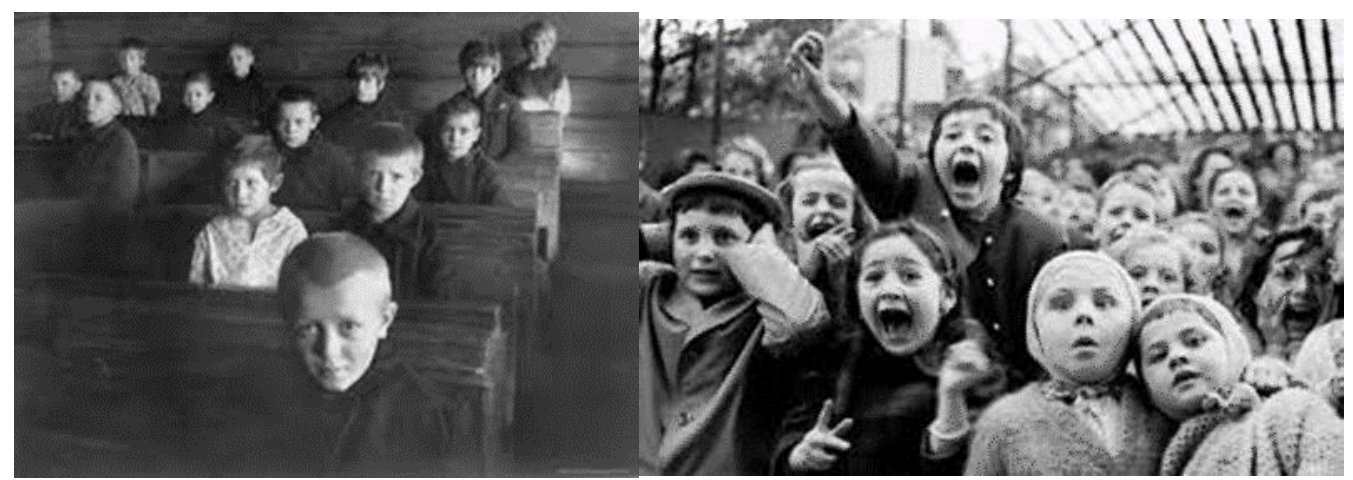

